\title{
EFEITO DA GRANULOMETRIA DO MILHO, ASSOCIADA À ÁREA POR ANIMAL, SOBRE O DESEMPENHO E LESÕES GÁSTRICAS DE SUÍNOS, NAS FASES DE CRESCIMENTO E TERMINAÇĀO.
}

\author{
(ÍCERO JUIANO MONTICELLI \\ Engenheiro Agrônomo
}

Orientador: Prof. Dr. JOSÉ FERNANDO MACHADO MENTEN

\begin{abstract}
Dissertação apresentada à Escola Superior de Agricultura "Luiz de Queiroz", da Universidade de São Paulo, para obtenção do título de Mestre em Agronomia, Área de concentração Ciência Anımal e Pastagens.
\end{abstract}

PIRACICABA

Estado de São Paulo - Brasil

Novembro - 1994 
Ficha catalográfica preparada pela seçāo de Livros da Divisão de Biblioteca e Documentação - PCLQ/USP

1. Milho para suíno - Desempenho 2. Milho para suino Digestibilidade 3. Suino - Alimentaçāo I. Escola superior de Agricultura Luiz de Queiron, Piracicaba 


\title{
EFEITO DA GRANULOMETRIA DO MILHO, ASSOCIADA À ÁREA POR ANIMAL, SOBRE O DESEMPENHO E LESÕES GÁSTRICAS DE SUÍNOS, NAS FASES DE CRESCIMENTO E TERMINAÇĀO.
}

\author{
CÍCERO JULIANO MONTICELLI
}

Aprovada em: 06.12.94

Comissão julgadora:

Prof. Dr. José Fernando Machado Menten

Prof. Dr. Valdomiro Shigueru Miyada

Dr. Gustavo Júlio Mello Monteiro de Lima
ESALQ/USP

ESALQ/USP

EMBRAPA/CNPSA

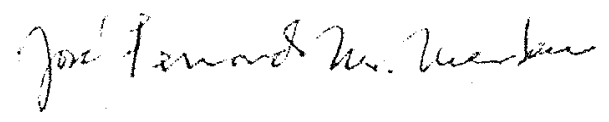

Prof. Dr. José Fernando Machado Menten Orientador 
Este trabalho é dedicado

À minha amada Lilian;

Às minhas filhas,

Bruna e Júlia.

À memória dos meus pais,

Luiz e Enela;

Aos meus irmãos,

Mariza, Gilmar e Reginaldo;

Aos meus sogros,

Raulino e Valéria; 


\section{AGRADECIMENTOS}

À Empresa Brasileira de Pesquisa Agropecuária (EMBRAPA) e ao Centro Nacional de Pesquisa de Suinos e Aves (CNPSA), pelo financiamento do curso de Mestrado.

À Escola Superior de Agricultura "Luiz de Queiroz" (ESALQ), através do CPG em "Ciência Animal e Pastagens", pelo oferecimento do curso.

Ao professor do Departamento de Zootecnia da ESALQ, Prof. Dr. José Fernando Machado Menten, pela amizade e orientação.

Aos professores do Departamento de Zootecnia da ESALQ pelos ensinamentos.

Ao colega do CNPSA, pesquisador Gustavo Júlio Mello Monteiro de Lima, pela amizade e auxilio durante todo o curso.

Ao amigo e colega do CNPSA, pesquisador Antonio Lourenço Guidoni, pelo convivio, auxilio na análise estatistica dos dados e revisão deste trabalho.

Aos amigos e colegas do CNPSA, pesquisadores Dirceu Zanotto, Nelson Mores e Jurij Sobestiansky, pela compreensão, auxilio e sugestões oferecidas na revisão deste trabalho.

Aos amigos Gilberto Silber Schmidt e Waldomiro Barioni Júnior pelo auxilio e estímulo constantes.

À Irene C. Zanatta, pela correção das referências bibliográficas.

Aos amigos e colegas de curso, pela convivência 
Aos funcionários do Departamento de Zootecnia, Setor de Não Ruminantes da ESALQ pelo apoio prestado.

Aos colegas do Centro Nacional de Pesquisa de Suínos e Aves.

A todos aqueles que contribuíram, direta e indiretamente, para que este trabalho fosse realizado. 


\section{SUMÁRIO}

Página

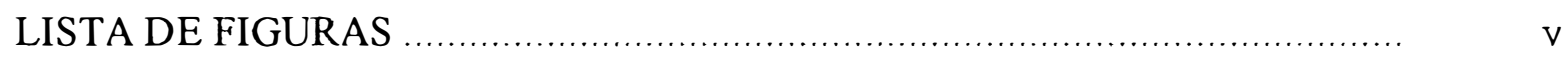

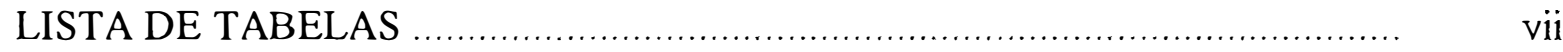

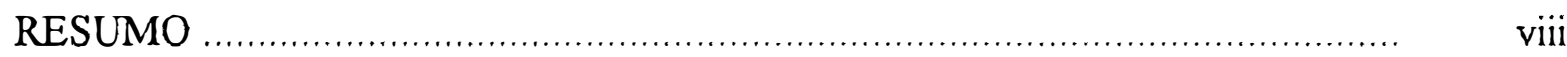

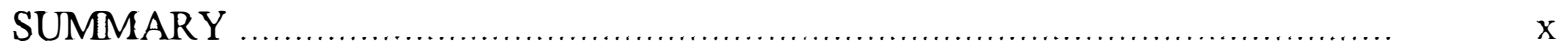

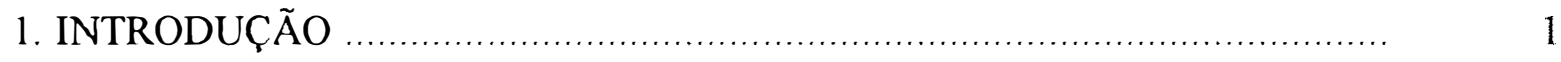

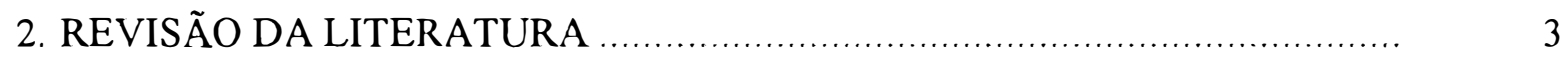

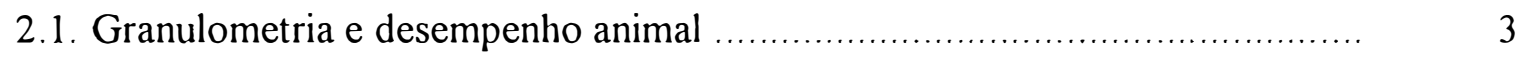

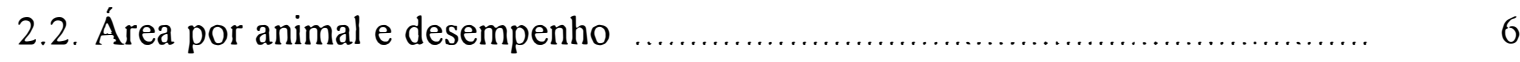

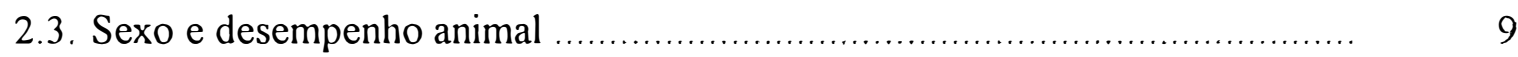

2.4. Granulometria, área por animal e lesões gástricas ................................. 11

3. MATERIAL E MÉTODOS …................................................... 16

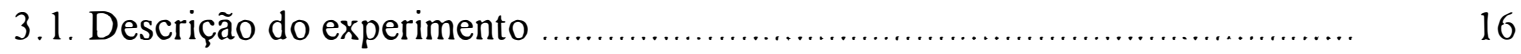

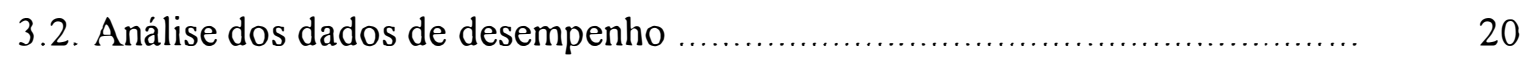

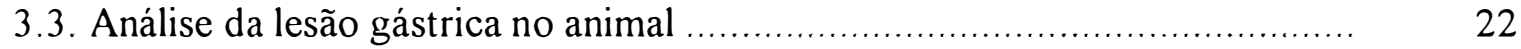

3.4. Associação dos tratamentos (granulometria e área por animal) e lesão gástrica sobre o desempenho animal ....................................... 23

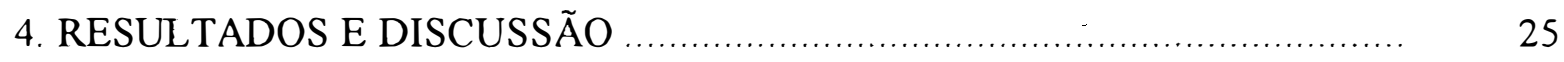

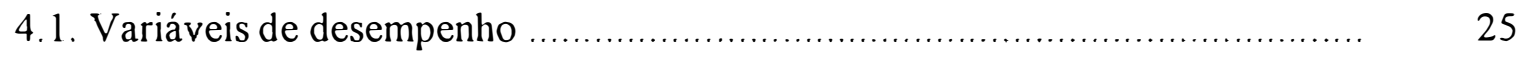

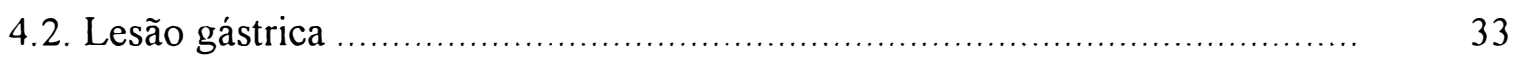

4.3. Associação dos tratamentos (granulometria e área por animal ) e lesão gástrica sobre o desempenho animal ......................................... 36

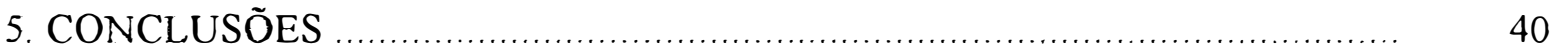

6. REFERÊNCIAS BIBLIOGRÁFICAS _............................................. 41

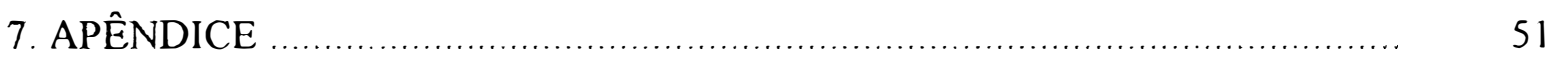




\section{LISTA DE FIGURAS}

Figura 1. Efeito da granulometria do milho da dieta sobre o consumo de ração diário (CRD) nas fases de crescimento ( 1 a 45 dias) e crescimento-terminação (1 a 87 dias)

Figura 2. Efeito da granulometria do milho da dieta sobre o ganho de peso diário (GPD) nas fases de crescimento ( 1 a 45 dias) e crescimento-terminação ( 1 a 87 dias)

Figura 3. Efeito da granulometria do milho da dieta sobre a conversão alimentar (CA) nas fases de crescimento ( 1 a 45 dias) e crescimento-terminação ( 1 a 87 dias)

Figura 4. Efeito da área por animal sobre o consumo de ração diário (CRD) nas fases de crescimento (1 a 45 dias) e crescimento-terminação ( 1 a 87 dias)

Figura 5. Efeito da área por animal sobre o ganho de peso diário (GPD) nas fases de crescimento (1 a 45 dias) e crescimento-terminação (1 a 87 dias)

Figura 6. Efeito da área por animal sobre a conversão alimentar (CA) nas fases de crescimento ( 1 a 45 dias) e crescimentoterminação ( 1 a 87 dias)

Figura 7. Efeito do sexo sobre o consumo de ração diário (CRD) nas fases de crescimento ( 1 a 45 dias) e crescimentoterminação (1 a 87 dias) 
Figura 8. Efeito do sexo sobre o ganho de peso diário (GPD) nas fases de crescimento ( 1 a 45 dias) e crescimento-terminação (1 a 87 dias)

Figura 9. Efeito do sexo sobre a conversão alimentar (CA) nas fases de crescimento (1 a 45 dias) e crescimento-terminação (1 a 87 dias)

Figura 10. Efeito da granulometria do milho sobre a incidência de lesão esôfago-gástrica após 87 dias de fornecimento das dietas experimentais

Figura 11. Efeito da área por animal sobre a incidência de lesão esôfagogástrica após 87 dias de fornecimento das dietas experimentais

Figura 12. Efeito do sexo sobre a incidência de lesão esôfago-gástrica após 87 dias de fornecimento das dietas experimentais.

Figura 13. Granulometria associada a lesão gástrica sobre o ganho de peso diário (GPD) na fase de crescimento-terminação

Figura 14. Área por animal associada a lesão gástrica sobre o ganho de peso diário (GPD) na fase de crescimento-terminação 


\section{LISTA DE TABELAS}

Tabela 1. Composição percentual e em nutrientes das dietas experimentais das fases de crescimento e terminação

Tabela 2. Efeito da granulometria (Gran) associada a lesões esôfagogástricas sobre o ganho de peso diário (GPD), em gramas (g), na fase crescimento-terminação

Tabela 3. Efeito da área por animal associada a lesões esôfagogástricas sobre o ganho de peso diário (GPD), em gramas (g), na fase crescimento-terminação 


\title{
EFEITO DA GRANUlOMETRIA DO MILHO, ASSOCIADA À ÁREA POR ANIMAL, SOBRE O DESEMPENHO E LESÕES GÁSTRICAS DE SUINOS, NAS FASES DE CRESCIMENTO E TERMINAÇÃO.
}

\author{
AUTOR: CÍCERO JULIANO MONTICELLI \\ ORIENTADOR: PROF. DR. JOSÉ FERNANDO MACHADO MENTEN
}

\section{RESUMO}

Com o objetivo de verificar o efeito da granulometria do milho da dieta e da área por animal sobre o desempenho e alterações gástricas em suínos, nas fases de crescimento e terminação, foi realizado o presente experimento no Centro Nacional de Pesquisas de Suínos e Aves (CNPSA/EMBRAPA), no Município de Concórdia, Estado de Santa Catarina.

$$
\text { Utilizou-se um delineamento experimental em tratamentos }
$$
casualizados em blocos e esquema fatorial $2 \times 3 \times 2$ (2 granulometrias (peneiras de 10,0 mm e $2,5 \mathrm{~mm}) \times 3$ áreas por animal $(0,64,1,07$ e 1,60 m²/animal) $\times 2$ sexos (macho castrado e fêmea)), totalizando 12 tratamentos. Para o estudo do efeito dos tratamentos sobre o desempenho dos suínos foram consideradas as variáveis ganho de peso diário (GPD), consumo de ração diário (CRD) e conversão alimentar (CA). Ao final do experimento, ocasião do abate, os estômagos dos suínos foram examinados visualmente quanto à frequência de alterações gástricas no Pars esofagea (PE).

Com base nos resultados obtidos concluiu-se que os suínos aproveitaram melhor o milho da dieta quando este foi fornecido com diâmetros de partículas menores, sendo que a granulometria mais fina proporcionou maior GPD e CRD e melhor CA. A restrição da área disponível ao animal piorou o desempenho de suinos, sendo que quando criados com $0,64 \mathrm{~m}^{2}$ de área tiveram pior desempenho do que suínos submetidos à $1,07 \mathrm{~m}^{2}$ e $1,60 \mathrm{~m}^{2}$. Os machos castrados ganharam mais peso e consumiram mais ração, porém tiveram pior CA do que fêmeas. A granulometria do milho da dieta influenciou a incidência de hiperqueratose e úlcera no PE do estômago de suínos em 
crescimento e terminação, sendo que maior frequência foi produzida pelo menor diâmetro das partículas, contudo, o grau destas alterações foi insuficiente para causar prejuizo no desempenho. Os suinos sofreram efeito detrimental no GPD quando apresentaram o PE ulcerado. 


\title{
EFFECT OF PARTICLE SIZE OF CORN AND SPACE ALLOWANCE PER ANIMAL ON THE PERFORMANCE AND GASTRIC LESIONS IN SWINE.
}

\author{
AUTHOR: CÍCERO JULIANO MONTICELLI \\ ADVISER: PROF. DR. JOSÉ FERNANDO MACHADO MENTEN
}

\section{SUMMARY}

The experiment was carried out at the CENTRO NACIONAL DE PESQUISA DE SUÍNOS E AVES (CNPSA/EMBRAPA), Concórdia, SC, Brazil. The objective was to evaluate the effects of particle size of corn and space allowance per animal on the performance and frequency of gastric lesions during the growing-finishing period.

The experimental design used was factorial ( 2 particle sizes (10,0 and 2,5 mm screens) $\times 3$ space allowance $\left(0,64,1,07\right.$ e 1,60 $\mathrm{m}^{2} /$ animal $) \times 2$ sexes (barrow and gilt)) with 12 treatments randomized in four blocks. The evaluated performance traits were: average daily gain (ADG), daily feed intake (DFI) and feed conversion (FC). The animals were slaughtered at $90 \mathrm{~kg}$ and visually examined for gastric lesion frequency in the Pars esophagea (PE) of stomach.

The performance of the growing-finishing pigs was improved when corn was ground to the smaller particle size. Space allowance of 1,07 or $1,60 \mathrm{~m}^{2}$ per pig resulted in better performance than $0,64 \mathrm{~m}^{2}$ per pig. Barrows had higher DWG and DFI than gilts, but the FC of the gilts was better. The frequency of hyperqueratosis and ulcer in the PE was higher in the pigs fed the corn with smaller particle size. However, this effect was not severe enough to depress performance. Pigs showing stomach ulcers, regardeless of dietary treatments, had a markedly lower DWG 


\section{INTRODUÇÃO}

O aprimoramento das técnicas de produção de suínos vem sendo alvo de muitas pesquisas, que têm como objetivo o aumento da produtividade, associada a maior rentabilidade. Neste contexto, os fatores de meio ambiente a que os animais são submetidos revestem-se de primordial importância na exploração dos suínos.

Dentre estes fatores, a alimentação representa de 70 a $80 \%$ dos custos de produção do suínos e, esforços no sentido de maximizar a eficiência de aproveitamento dos alimentos devem ser dispendidos. Para tanto, acredita-se que o grau de moagem do milho, cereal que tradicionalmente contribui com cerca de $70 \%$ na composição das rações, poderia influenciar o desempenho dos suínos, uma vez que a diminuição do tamanho da partícula deste alimento permitiria melhorar o aproveitamento dos nutrientes.

No que concerne à área disponivel ao animal é comum considerar-se que, para conseguir máxima eficiência de utilização das instalações para suínos em crescimento e terminação, deve-se colocar o maior número possível de animais numa dada área. Diminuindo-se a área para o suíno, modificam-se o ambiente e o comportamento do animal, podendo afetar o seu desempenho.

Acredita-se que alterações no tamanho da partícula dos alimentos, como também, modificação na área disponivel por animal, poderiam ter influência sobre o desenvolvimento de lesões ulcerativas na mucosa da região esofago-gástrica (Pars esofagea) do estômago dos suínos.

$\mathrm{Na}$ verdade, observa-se uma grande variabilidade nos resultados de pesquisas realizadas até o presente momento, com fortes evidências de interação genótipo ambiente, devido à utilização de diferentes raças, cruzamentos, condições de manejo, clima, entre outros. 
Para estudar os efeitos dos fatores citados anteriormente, isolados ou associados, sobre o desempenho e alterações gástricas de suínos nas fases de crescimento e terminação, na região Sul do Brasil, foi realizada a presente pesquisa, objetivando:

1) Verificar o efeito da granulometria do milho no desempenho dos suínos em crescimento e terminação;

2) Verificar o efeito da área disponivel ao animal no desempenho dos suínos em crescimento e terminação;

3) Verificar se a granulometria do milho moído e a área disponível ao animal, independentemente e/ou de forma associada, afetam a frequência de alterações gástricas no Pars esofagea dos suínos em crescimento e terminação. 


\section{REVISÃO DA LITERATURA}

\subsection{Granulometria e desempenho animal}

No estudo da eficiência de aproveitamento dos alimentos, diversos fatores podem ser considerados. Dentre esses fatores, a granulometria vem sendo alvo de intensas pesquisas, visando detectar limites de tamanho de partículas que proporcionem o máximo aproveitamento do alimento.

A superficie de exposição dos alimentos às ações das secreções digestivas, presentes no trato gastrointestinal dos suínos, pode influenciar a digestão dos mesmos. Desse modo, alimentos com diferentes tamanhos de partículas podem resultar em diferentes digestibilidades de seus nutrientes, conforme constatado por CRAMPTON $\varepsilon$ BELL (1946), IVAN et alii (1974), LIMA et alii (1990) e ZANOTTO (1992).

Na mastigação, os grãos são parcialmente quebrados em partículas menores. Grãos pequenos e duros são mais dificeis de quebrar, podendo passar através do trato alimentar sem serem utilizados. A moagem dos grãos reduz o tamanho da partícula, aumentando sua área de superfície, expondo uma grande área para a ação das enzimas digestivas. WU $\varepsilon$ ALLEE ${ }^{\prime}$, citados por LIPTRAP $\varepsilon$ HOGBERG (1991), registram que a área de superficie diminui linearmente com o aumento do tamanho da partícula. POND $\varepsilon$ MANER (1974) comentam que os grãos de cereais ou cereais moídos grosseiramente e que não são mastigados de forma adequada pelos suínos, passam através do trato digestivo sem sofrerem uma digestão satisfatória, pois têm uma menor área de contato exposta às ações das secreções digestivas do trato gastrointestinal. Realizando uma revisão bibliográfica, para observar o efeito do grau de moagem dos grãos sobre sua utilização pelos suínos em crescimento e terminação, LAWRENCE (1972) constatou que os alimentos com menor 
tamanho de partículas eram melhor digeridos do que os alimentos com maior tamanho de partículas.

Vários estudos têm relacionado a granulometria de diversos alimentos ao desempenho dos suínos. POTKINS $\varepsilon$ LAWRENCE (1989) observaram efeitos benéficos da redução do tamanho das partículas da cevada no desempenho dos suínos dos 20 aos 90 $\mathrm{kg}$ de peso. Estudando o efeito da granulometria de ingredientes de dietas complexas sobre o desempenho de suinos em crescimento e terminação, THOMAS $\varepsilon$ SINGH (1984) não observaram diferenças no ganho de peso diário (GPD) e na conversão alimentar (CA) pelo fornecimento de dietas à base de mandioca desidratada, farelo de nozes, milho e farinha de peixe, quando estas oriundas de peneiras entre 2 a $3 \mathrm{~mm}$ ou menores do que $1 \mathrm{~mm}$ KIRCHGESSNER et alii (1985), por sua vez, encontraram resultados diferentes no desempenho de suinos submetidos a dietas complexas. Segundo estes autores, dietas à base de farinha de peixe, farelo de soja, trigo, cevada e aveia, com granulometria fina (peneira de $1,5 \mathrm{~mm}$ ), determinaram diminuição do consumo de ração diário (CRD) e GPD dos suinos, porém, com a CA ligeiramente melhor, em relação à granulometria grossa (peneira de $3,5 \mathrm{~mm})$.

Segundo LIPTRAP ع HOGBERG (1991), a eficiência alimentar (EA) é geralmente melhorada quando os alimentos são moídos mais finamente e que o desempenho é melhorado quando o suino recebe grãos de trigo ou sorgo moídos, em comparação ao grão inteiro. HALE $\varepsilon$ THOMPSON (1986) e SEERLEY et alii (1988) detectaram que o trigo moído grosseiramente resultou em melhor CA, sendo que SEERLEY et alii (1988) observaram também melhor GPD. CABRERA et alii (1994) estudaram o efeito do tamanho da partícula do sorgo em suínos em crescimento e terminação e encontraram uma melhora linear na EA quando o tamanho da partícula do sorgo nas dietas foi reduzida de 800 para $400 \mu \mathrm{m}$. Entretanto, LUCE ${ }^{2}$, citado por LIPTRAP $\varepsilon$ HOGBERG (1991), mostrou que a redução do tamanho da partícula do sorgo não melhorou o desempenho dos suínos.

As evidências de efeitos benéficos de dietas à base de milho moído com granulometrias mais finas, no desempenho de suínos em crescimento e terminação, foram constatadas em diversos trabalhos. TRIVELIN et alii (1969), estudando o efeito do grau de moagem do milho, obtiveram GPD de 11,6 e 16,5\% maiores para suínos que 
receberam quirera grossa e quirera fina, respectivamente, em relação aos animais que receberam milho na forma de grãos inteiros. Além disso, segundo os autores, a CA foi tanto melhor quanto mais finamente moído o milho. Resultados similares foram obtidos por PICKETT et alii (1969), HEDDE et alii (1985) e OHH et alii (1985), embora não tenham detectado efeito significativo no GPD dos leitões, verificaram redução no CRD e melhora na $\mathrm{CA}$ quando os animais foram alimentados com dietas contendo milho moído com granulometria mais fina. Para ZANOTTO (1992), a granulometria do milho nas rações influenciou o desempenho dos suínos nas fases de crescimento e terminação. Melhor CA e menor CRD, sem prejuizo ao GPD, foram obtidos quando o milho moído apresentou módulo de finura variando de 2,29 a 2,63, ou diâmetro geométrico médio das partícula compreendido entre 509 a $645 \mu \mathrm{m}$ quando comparado com granulometrias mais grossas.

De outra forma, os resultados obtidos nos estudos de MAHAN et alii (1966), REIMANN et alii (1968) e YANG et alii (1988) não permitiram evidenciar diferenças entre graus de moagem do milho sobre o desempenho dos suínos em crescimento e terminação. HSU et alii (1985) concluíram que o tamanho da partícula do milho (472 e $690 \mu \mathrm{m}$ ) não afetou o desempenho dos suínos em crescimento e terminação.

Nos trabalhos realizados visando estudar o efeito da granulometria dos alimentos sobre o desempenho de suínos em crescimento e terminação, observa-se o uso de arraçoamento à vontade e controlado. De maneira genérica, quando o fornecimento de ração foi à vontade o GPD não aumentou com a diminuição do tamanho da partícula, porém o CRD foi menor e a CA foi melhorada. Por outro lado, quando o fornecimento foi controlado, a redução no tamanho das partículas melhorou o GPD. De acordo com ZANOTTO et alii $^{3}$ uma explicação plausível para este fato, é que, sob o regime de alimentação à vontade e recebendo uma dieta de menor digestibilidade (granulometrias mais grossas), os suínos consomem mais ração, para atenderem suas necessidades em energia e nutrientes, em relação aos animais que receberam uma dieta de melhor digestibilidade (granulometrias mais finas) e, desta forma, possíveis prejuízos no GPD são compensados. De maneira geral, pode-se inferir que, para ambos os regimes de alimentação, as dietas contendo granulometrias mais finas proporcionam melhor desempenho aos suínos do que granulometrias mais grossas.

\footnotetext{
${ }^{3}$ ZANOTIO, D.L.; FERREIRA, A.S.; NICOLAIEWSKY, S.: GUIDONI, A.L.; LIMA, G.I.IM.M. de. Granulometria do milho das raçōes no
} desempenho de suinos em crescimento e crescimento-terminação. (no prelo). 


\section{2. Área por animal e desempenho}

A área necessária por suíno, para um máximo desempenho, é um fator importante a ser considerado no planejamento e manejo de sistemas modernos de produção de suínos. Falhas no planejamento da área adequada por suíno causam problemas de superlotação, de organização da produção e inúmeras interações entre os animais.

Se, por um lado, a utilização de poucos animais por baia aumenta o investimento inicial em instalações e equipamentos, deve ser considerado que a restrição do espaço disponível ao animal pode provocar superlotação. A restrição da área traz como resultado o canibalismo, a redução no ganho de peso, uma piora da conversão alimentar, o aparecimento de úlceras gástricas e/ou outros fatores estressores aos suínos e o aumento na susceptibilidade a doenças nos suínos.

Diversos autores, entre eles GELBACH et alii (1966), KRIDER et alii (1975), FRITSCHEN $\varepsilon$ MUEHLING (1979), PETHERICK $\varepsilon$ BAXTER (1982), KORNEGAY $\varepsilon$ NOTTER (1984) e HSIA $\varepsilon$ LU (1985) recomendaram diferentes áreas por animal que poderiam permitir a eficiência máximo no desempenho de suínos.

É bem conhecido que o desempenho individual do suíno em crescimento e terminação diminui quando o seu espaço é restringido. Portanto, para que se possa proporcionar uma área para o suíno, que vise maximizar a sua produção, numa dada instalação, torna-se necessário conhecer a relação entre o espaço disponível ao animal e o seu desempenho.

KORNEGAY \& NOTTER (1984) realizaram uma revisão sobre a área por animal e seu efeito sobre o desempenho dos suínos. Para tanto, determinaram a relação entre a área por animal e o desempenho usando um modelo ajustado para diferentes médias de dados de diversos estudos e que ponderou cada média pelo número de repetições. Eles observaram que o GPD e o CRD aumentaram quando a área por animal aumentou. Entretanto, o efeito do aumento do espaço por suíno sobre a CA foi muito menor. Além disso, o acréscimo no GPD foi devido, principalmente, ao aumento no CR. Por exemplo, com uma área de $0,3 \mathrm{~m}^{2}$, o GPD de suínos em crescimento aumentou em $5,2 \%$, o CR 
aumentou em $3,2 \%$ e a CA melhorou $1,6 \%$ para cada $0,1 \mathrm{~m}^{2}$ de acréscimo na área. Para suínos em terminação, com $0,70 \mathrm{~m}^{2}$ de espaço, o GPD aumentou em 2,6\%, o CR aumentou em $2,3 \%$ e a CA diminuiu em $0,4 \%$ para cada $0,1 \mathrm{~m}^{2}$ de acréscimo na área por animal. Ainda nessa revisão, KORNEGAY $\varepsilon$ NOTTER (1984) determinaram que os espaços obtidos pela equação de predição e que proporcionaram o máximo ganho de peso foram 0,92 e $1,04 \mathrm{~m}^{2}$ por suíno, nas fases de crescimento e terminação, respectivamente. Encontraram, também, que a equação que melhor representava a relação entre a área por animal que resulta em melhor desempenho foi $\mathrm{A}=0,048 \cdot \mathrm{PC}^{\frac{2}{3}}$, onde $\mathrm{A}$ representa a área por animal e PC representa o peso corporal do animal $\left(\mathrm{PC}^{\frac{2}{3}}=\right.$ peso metabólico $)$, diferentemente de PETHERICK $\varepsilon$ BAXTER (1982) que determinaram a equação como sendo $\mathrm{A}=0,034 \cdot \mathrm{PC}^{\frac{2}{3}}$

A superlotação que freqüentemente ocorre em sistemas intensivos de produção de suínos pode se dar de duas formas: através da diminuição da área por animal e através do aumento do número de suínos por grupo.

GELBACH et alii (1966) sugeriram que a área por animal, requerida por suínos em crescimento e terminação para obterem GPD e CRD máximos, poderia ser afetada pelo tamanho do animal, pelo tamanho de grupo, pela temperatura ambiente e outros fatores ambientais, pelo tipo da baia, pelo material do piso e pelo método de arraçoamento.

JENSEN (1973), estudando a resposta no desempenho de suínos em crescimento e terminação, alojados em diferentes áreas e sobre baias com piso semi ou totalmente ripado, concluíram que o GPD diminuiu com a restrição de área e que houve diferença no CRD quando os animais foram criados em baias com piso parcialmente ripado, mas que não houve diferença quando sob piso totalmente ripado. Detectaram também, que a EA não foi afetada pela disponibilidade de área por animal.

Estudos científicos que têm examinado os efeitos separados de tamanho de grupo e área por animal indicam que ambos os fatores podem afetar o desempenho animal. Porém, observa-se que a restrição da área por animal tem um efeito mais consistente sobre o desempenho do suíno, em comparação ao aumento do número de animais por grupo. Segundo KORNEGAY \& NOTTER (1984), quando o número de súnos 
por baia foi variado e o espaço por suino mantido constante, houve um pequeno decréscimo no GPD quando o número de suínos por baia aumentou e este efeito foi maior somente para suinos na creche, e não para suinos em crescimento e terminação.

MADSEN $\varepsilon$ NIELSEN (1979) observaram que, quando os suínos foram alimentados com ração controlada, o GPD diminuiu linearmente com o aumento do número de suínos por baia de 8 para 32. Entretanto, quando o suínos foram alimentados à vontade, não houve diferença no GPD dos animais.

Segundo RANDOLPH et alii (1981), que estudaram as variáveis área por animal $\left(0,82,1,25\right.$ e 1,64 $\left.\mathrm{m}^{2}\right)$ e tamanho de grupo (5, 13 e 20 animais/baia) para suinos em crescimento e terminação, a área por animal teve um efeito maior sobre o desempenho dos suínos do que o tamanho de grupo e que estes fatores afetaram o desempenho independentemente, uma vez que não houve interação entre eles, para GPD, CRD e CA. Eles encontraram que o GPD dos suínos, até $89,5 \mathrm{~kg}$, não foi afetado pelo tamanho do grupo, mas diminuiu linearmente quando a área por animal decresceu. Estes resultados foram similares aos de HEITMAN (1961), HANKE $\varepsilon$ MEADE (1973) e BRYANT $\varepsilon$ EUBANK (1974), que não observaram diferenças no GPD entre suinos mantidos em diferentes tamanhos de grupo. Por outro lado, HEITMAN (1961), JENSEN (1973) e BRYANT $\varepsilon$ EUBANK (1974) encontraram que o GPD diminuiu quando a de área por animal foi diminuída.

MILLER (1976) e MADSEN $\varepsilon$ NILSON (1979), encontraram que o GPD foi menor para suinos em grupos maiores do que para suinos em grupos menores. GELBACH et alii (1966) observaram efeito detrimental sobre o GPD devido à restrição de espaço por animal na fase de crescimento, mas não detectaram o mesmo efeito na fase de terminação. EDWARDS et alii (1988) concluiram que, para suínos em crescimento alojados em baias de piso compacto e com alimentação à vontade, o acréscimo na disponibilidade de espaço aumentou o GPD. Ainda neste experimento, o CRD não foi afetado, mas a CA foi pior para animais submetidos à menor área. 
MOREIRA (1981) observou que para suínos em crescimento e terminação a restrição da área por animal determinou queda no GPD e CRD (efeito quadrático), bem como, decréscimo linear na EA.

HSIA $\varepsilon$ LU (1985) estudaram o efeito da área por suíno $\left(0,82 \mathrm{~m}^{2}\right.$, $0,96 \mathrm{~m}^{2}$ e $1,12 \mathrm{~m}^{2}$ ) nas fases de crescimento e terminação e não observaram diferença entre os tratamentos quando os suínos testados pesavam entre 18,7 e $80,9 \mathrm{~kg}$. Entretanto, houve efeito sobre o GPD quando os suínos pesavam entre 80,9 e 108,3 kg. Neste caso, os suínos tiveram GPD menor quando o espaço foi de $0,82 \mathrm{~m}^{2}$ comparado com $0,96 \mathrm{~m}^{2}$ e não houve diferença no CRD e CA. MEUNIER-SALAUN et alii (1987) observaram que o aumento da área por animal $\left(0,34 \mathrm{~m}^{2}, 0,68 \mathrm{~m}^{2}\right.$ e $\left.1,01 \mathrm{~m}^{2}\right)$ proporcionou, na fase de crescimento melhora na CA e, na fase de terminação melhorias no GPD e CA. Não detectaram efeito sobre o CRD

\subsection{Sexo e desempenho animal}

Nas últimas décadas, muitos experimentos foram realizados com o objetivo de estudar a diferenças entre sexos, para as características de desempenho dos suínos.

Os efeitos do sexo do suíno sobre a eficiência de utilização do alimento não têm sido consistentes, conforme análise dos trabalhos de HALE $\varepsilon$ SOUTHWELL (1967), BAYLEY \& SUMMERS (1968), BRUNER \& SWIGER (1975), SIERS (1975), CHRISTIAN et alii (1980) e BERESKIN \& STEELE (1988). A conclusão genérica foi que machos inteiros são mais eficientes que machos castrados, com a eficiência de fềmeas, em relação aos machos castrados, sendo mais variável.

No que concerne à taxa de crescimento, TURTON ${ }^{4}$, citado por HANSSON (1974), realizou uma revisão sobre o efeito da castração sobre a produção de suínos e concluiu que na média do GPD, os machos inteiros foram superiores aos machos castrados em cerca de $45 \%$ dos trabalhos analisados. Em aproximadamente $20 \%$ dos

\footnotetext{
${ }^{4}$ TURTON, J.D. The effect of castration on meat production from cattle, sheep and pigs. In: RHODES, D.N. Meat production from entire animals, London, 1969. p. 1-5
} 
estudos não houve diferença devido à castração e no restante dos trabalhos os machos castrados foram superiores aos machos inteiros. A grande variação nos resultados concernentes à taxa de crescimento pode depender das raças e faixas de idade dos suinos, das diferentes rações e manejo do arraçoamento, entre outros fatores.

CASTELL et alii (1986) compararam machos inteiros, machos castrados e fêmeas, todos mestiços das raças (Hampshire $\mathrm{x}$ (Landrace x Yorkshire)). Neste estudo, os machos castrados cresceram $12 \%$ mais rápido do que as fêmeas. $\mathrm{O}$ crescimento mais rápido estava associado com um acréscimo similar (13 \%) no $\mathrm{CRD}$ Consequentemente, a eficiência de utilização do alimento foi similar para ambos os sexos. WATKINS et alii (1977) avaliaram machos inteiros e fêmeas de muitas raças e cruzamentos e concluíram que os machos inteiros cresceram $8 \%$ mais rápido do que fêmeas. SCHIRVEL $\varepsilon$ HANSET (1988), em um estudo com suínos da raça Pietrain, de 24,5 a 96,5 kg, observaram que machos castrados tiveram maior GPD do que fêmeas.

KUAN \& MARK (1983) observaram que fêmeas suínas da raça Chester White, na fase de terminação (52 a $90 \mathrm{~kg}$ ), ganharam peso mais rápido e tiveram melhor CA do que machos castrados. BERESKIN $\varepsilon$ STEELE (1988) encontraram que fêmeas Duroc cresceram $3 \%$ mais rápido do que machos castrados, enquanto que machos inteiros da raça Yorkshire cresceram 8 \% mais do que fêmeas. MAHAN $\varepsilon$ GERBER (1985), trabalhando com suínos na fase de terminação (60 a $135 \mathrm{~kg}$ ), com ração à vontade, concluíram que machos castrados tiveram maior GPD e consumiram $100 \mathrm{~g}$ a mais para cada unidade de ganho do que as fêmeas.

BURRIS et alii (1986) estudando o efeito do sexo sobre o desempenho de suínos em crescimento-terminação não encontraram diferenças na EA, mas os machos inteiros tiveram maior GPD e CRD do que fêmeas. WALKER (1989), estudando o efeito de sexos, observou que machos inteiros tiveram maior CRD e GPD mas pior EA. HSIA $\varepsilon$ LU (1985) encontraram que machos castrados tiveram maior GPD que fêmeas, nas fases de crescimento e terminação.

Estudando o efeito da área por animal sobre o desempenho de machos castrados e fêmeas em crescimento e terminação, alojados em baias com piso parcialmente e totalmente ripado e alimentados à vontade, JENSEN et alii (1973) observaram que os machos castrados ganharam peso mais rapidamente e consumiram mais ração do que as 
fềmeas, porém, quando alojados em piso totalmente ripado as fêmeas tiveram melhor EA do que os machos castrados. WALKER (1989), pesquisando a área por animal e sexo, não observou efeitos significativos da área por animal $\left(0,57,0,71\right.$ e $\left.0,95 \mathrm{~m}^{2}\right)$ sobre o CR e CA, mas machos inteiros tiveram um GPD maior e melhor CA do que fêmeas. Ambos os trabalhos concluíram que não houve interação entre sexo e espaço por animal, detectando que machos castrados e fêmeas, nas fases de crescimento e terminação, respondem similarmente à disponibilidade de área por animal.

\subsection{Granulometria, área por animal e lesões gástricas}

As lesões gástricas são comumente encontradas nos animais domésticos, principalmente naqueles submetidos aos modernos sistemas de produção.

Em suínos, reconhecem-se dois tipos de úlcera estomacal: a úlcera péptica, que afeta a região glandular (principalmente na região fúndica e raramente nas regiões cárdica e pilórica) e a úlcera esofagogástrica, que ocorre na região não glandular ou Pars esofagea (PE) do estômago (MAHAN et alii, 1966; O'BRIEN, 1992).

O PE do estômago é reconhecidamente um local de alta vulnerabilidade à ulceração. Segundo O'BRIEN (1992) a área de superficie do PE nos suínos varia de acordo com o tamanho do animal. É de aproximadamente 50 a $80 \mathrm{~mm}$ de comprimento e 40 a $50 \mathrm{~mm}$ de largura em suínos de 70 a $90 \mathrm{~kg}$. O PE é recoberto com um epitélio escamoso estratificado, contínuo com o esôfago. Normalmente esta superficie é branca, macia e brilhante e desprovida de glândulas secretoras. A camada do epitélio termina abruptamente na junção do $\mathrm{PE}$ e região cárdica.

Segundo MARQUES et alii (1989) as úlceras gástricas podem ocorrer em todas as idades do animal, mas a maior freqüência tem sido observada entre 3 a 8 meses de idade do suíno.

A incidência e a localização das lesões gástricas em suínos foram verificadas por MUGGENBURG et alii (1964). Dos 3.753 suínos examinados, os autores encontraram $1.513(40,3 \%)$ com estômagos normais, 1.640 (43,7\%) com alterações 
epiteliais na região esofagogástrica e $600(16 \%)$ com erosões, úlcera ou úlcera cicatrizada. Dos 600 estômagos ulcerados, em 523 (87,1 \%) a lesão localizava-se no PE. CIACCI et alii (1991), avaliando 417 suínos, em Concórdia-SC, observaram que em 99 animais $(23,74 \%)$ foram detectadas lesões ulcerativas, todas localizadas no PE do estômago. A prevalência das alterações epiteliais e/ou gástricas dos suíno na região esofagogástrica do estômago também foi demonstrada nos estudos de SIMONSSON $\varepsilon$ BJÖRKLUND ${ }^{5}$, citados por O'BRIEN (1992), TAMÁS et alii (1983) e KIRCHGESSNER et alii (1985).

A etiologia da úlcera gástrica parece ser complexa e multifatorial. A sua incidência é dependente da ação de certos fatores de alimentação (granulometria do alimento), modo de arraçoamento e também da intensificação tecnológica do sistema de exploração. Assim, a constituição dos lotes de animais (agrupamento), o transporte e a elevada densidade (redução da área disponível por animal) são fatores que agravam a severidade das lesões, embora não aumentem sua freqüência.

Dentre os muitos fatores que contribuem para o desenvolvimento de processos ulcerativos, a alimentação com grãos finamente moídos, que induz o aumento das secreções e aumento da mistura dos conteúdos gástricos, é comumente considerada.

Um acréscimo na incidência de ulceração foi produzido pelo uso de dietas com grãos finamente moídos quando comparadas com grãos grosseiramente moídos (REIMANN et alii, 1968; MAXWELL et alii, 1970; SIMONSSON $\varepsilon$ BJÖRKLUND ${ }^{5}$, citados por O'BRIEN, 1992). Os dados destes experimentos demonstraram que, como um resultado da ingestão de alimentos com partículas finas, os conteúdos foram mais fluídos, houve menos matéria seca nos conteúdos estomacais e houve aumento dos conteúdos gástricos, resultando no aumento da acidez e atividade da pepsina na região do PE. A taxa de passagem dos conteúdos do estômago também foi aumentada (MAXWELL et alii, 1970). Esses resultados consubstanciaram as observações que indicavam que estômagos afetados continham pouco alimento sólido, eram fluídos e tinham um pH baixo. REIMANN et alii (1968) indicaram que o efeito do tamanho da partícula da dieta sobre as lesões gástricas resultou de uma alteração na atividade da pepsina, fluidez dos conteúdos estomacais, ou ambos, e não por uma diminuição na secreção de muco ou aumento na secreção ácida.

\footnotetext{
${ }^{5}$ SMMONSSON, A.; BJÖRKLUND, N.E. Some effects of the fininess of ground barley on gastric lesions and gastric contents in growing pigs. Vitamins and Hormones., New York, 20:645-657, 1978.
} 
BERRUECOS $\varepsilon$ ROBINSON (1972), na Carolina do Sul-EUA, registraram que a presença de úlceras não é causa da redução no GPD e da eficiência de utilização do alimento. DOBSON et alii (1978), na Austrália, mostraram em seus experimentos com granulometria fina que não houve diferença significativa no GPD e CA, embora alimentos com grãos finamente moídos produziram mais ulceração. Por sua vez, CURTIN et alii (1963) observaram diminuição do GPD e aumento na progressão da síndrome com a utilização de alimentos com tamanhos pequenos de partículas.

Para KIRCHGESSNER et alii (1985) a granulometria fina diminuiu significativamente o CRD e o GPD. A CA foi melhorada ligeiramente, enquanto que a digestibilidade dos nutrientes brutos e energia, durante o período de terminação, foi significativamente aumentada. A ração finamente moída provocou hiperqueratose mais intensa no PE do estômago do que a grosseiramente moída. As erosões somente foram detectadas após o uso da ração fina e nenhuma ulceração foi observada.

POTKINS $\varepsilon$ LAWRENCE (1989) observaram que a utilização de granulometria de dietas com cevada moída em peneira de $1,56 \mathrm{~mm}$, comparada com cevada moída em peneira de $4,68 \mathrm{~mm}$, aumentou a incidência e severidade de úlceras no PE do estômago.

Para ZANOTTO (1992) o uso de granulometria fina do milho (módulo de finura entre 2,29 e 2,63) na ração determinou aumento na frequência de alterações epiteliais na parede do PE do estômago mas não houve desenvolvimento de úlcera e o grau dessas alterações foi insuficiente para causar prejuizo no desempenho de suínos em crescimento e terminação. STRAW et alii (1994) estudando a prevalência de úlceras gástricas em suínos terminados observaram que a diminuição no tamanho da partícula $(700 \mu \mathrm{m}$ para $550 \mu \mathrm{m})$ aumentou a severidade de ulceração. WONDRA et alii (1994) estudaram o efeito do tamanho da partícula do milho sobre porcas de segundo parto e não observaram efeito sobre a perda de peso e a espessura de toucinho da porca e nem sobre o desempenho da leitegada mas, a diminuição do tamanho da partícula aumentou a severidade de úlceras estomacais. CABRERA et alii (1994) estudaram o efeito do tamanho da partícula do sorgo e encontraram uma melhora linear na EA quando o tamanho da partícula das dietas foi reduzido de $800 \mu \mathrm{m}$ para $400 \mu \mathrm{m}$ e um aumento na incidência e severidade de lesões gástricas. 
WU et alii $(1986,1989)$ trabalhando com diferentes tamanhos de partículas do milho (sendo a menor de $700 \mu \mathrm{m}$ e a maior de $1368 \mu \mathrm{m}$ ), oriundos de moinhos de martelo e de cilindro, concluíram que a incidência de úlcera gástrica, bem como o ganho de peso, o consumo de ração e a EA, não foram afetados pelo tamanho da partícula. Já, WU et alii (1987), estudando o efeito do tamanho da partícula do sorgo, não observaram efeito sobre o GPD e incidência de úlcera mas, concluíram que o $\mathrm{CRD}$ aumentou $(\mathrm{P}<0,05)$ com o aumento do tamanho da partícula. LIN et alii (1988) também não detectaram efeito do tamanho da partícula da dieta na incidência de úlcera gástrica em suínos nas fases de crescimento e terminação.

A ração com granulometria muito fina aumenta o consumo de água e facilita a formação de um bolo alimentar mais fluido no estômago, com pH mais ácido, o que permite maior tempo de contato com a região esofageana e, consequentemente, o desenvolvimento de lesões ulcerativas (MAXWELL et alii, 1970; HEDDE et alii, 1985; KIRCHGESSNER et alii, 1985). Esses autores verificaram um aumento na incidência de úlcera esofagogástrica em suínos alimentados com rações contendo granulometria oriunda de peneiras inferiores a $1,5 \mathrm{~mm}$ ou $1,0 \mathrm{~mm}$.

Os alimentos mais grossos e com mais fibra permitem uma estratificação dos mesmos no estômago, prevenindo o contato do suco gástrico com a região esofageana, além de facilitar o esvaziamento do estômago (MORAN Jr, 1982).

Situações estressantes a que os suínos são submetidos, tais como, pesagens semanais (CIACCI et alii, 1991), superlotação e medo (MUGGENBURG et alii, 1967) e amplas flutuações térmicas (RIKER III et alii, 1967b) podem levar ao aparecimento de úlceras no PE.

O estresse crônico provoca produção contínua de glicocorticóides pela glândula adrenal, que por sua vez, parece aumentar a produção de ácido clorídrico e pepsina no estômago, aumentando a susceptibilidade da área esofageana a lesões ulcerativas (RIKER III et alii, 1967a). Além disso, em animais sob condição de estresse contínuo, ocorre o desenvolvimento de uma microflora estomacal que, na presença de substrato no estômago, prolifera-se rapidamente. Esta flora entra em contato com o epitélio da região esofageana por períodos longos, principalmente se a taxa de esvaziamento do estômago for 
reduzida, o que favorece o desenvolvimento de lesões ulcerativas (TANNOCK $\varepsilon$ SMITH, 1970).

MUGGENBURG et alii (1967) concluiram que o número de suinos por lote, independentemente da área por suíno e restrição de 23 a $40 \%$ do espaço disponivel, não afetou o desenvolvimento de úlceras esofagogástricas. HANDLIN et alii (1972), estudando o efeito da restrição do espaço por animal; sobre a incidência de úlceras estomacais em suínos SPF (Duroc e Hampshire), encontraram que a redução da área por animal $\left(1,28\right.$ para $\left.0,79 \mathrm{~m}^{2}\right)$ não aumentou o número de úlceras. MOREIRA (1981) não observou interação entre densidade populacional e úlcera, concluindo que não houve efeito do aumento da densidade populacional sobre a incidência de ulcerações gástricas. Contrariamente, PICKETT et alii (1969) observaram uma redução significativa no GPD e um aumento na freqüência de lesões esofagogástricas quando o espaço disponivel por suino foi reduzido de $1,1 \mathrm{~m}^{2}$ para $0,55 \mathrm{~m}^{2}$.

Segundo SENK (1986), que estudou a incidência e complicą̧ões de úlcera gástrica em suínos, as lesões iniciais do PE ocorrem em igual incidência nos machos e fêmeas, mas uma maior tendência para um desenvolvimento mais progressivo da lesão, foi observada em machos castrados. MUGGENBURG et alii (1964), por sua vez, concluíram que machos castrados tiveram uma maior incidência de úlceras gástricas do que as fêmeas. Por outro lado, HESSING et alii (1992), estudando a prevalência de estresse sobre lesões no PE dos suinos, na Holanda, não observaram relação entre lesões gástricas e sexo dos animais.

Finalizando esta revisão da literatura, torna-se importante frisar que se observa uma grande variabilidade nos resultados de pesquisa onde se avaliou o efeito do tamanho da partícula dos alimentos e da área por animal, de maneira isolada ou associada, sobre o desempenho e alterações gástricas de suinos, com fortes evidências de interação genótipo $\mathrm{x}$ ambiente, devido a utilização de diferentes raças, cruzamentos, fases de vida do animal, condições de manejo, clima, entre outros fatores. 


\section{MATERIAL E MÉTODOS}

\section{1. Descrição do experimento}

O experimento foi realizado nas instalações do Centro Nacional de Pesquisa de Suinos e Aves (CNPSA), da Empresa Brasileira de Pesquisa Agropecuária (EMBRAPA), situado em Concórdia-SC e sua condução ocorreu no período de abril a setembro de 1993.

Foram utilizados 320 suinos cruzados (Landrace $x$ Large White), sendo $50 \%$ machos castrados e $50 \%$ fêmeas, com peso médio inicial de $24,83 \pm 0,13 \mathrm{~kg}$ e idade em torno de $73 \pm 0,3$ dias.

Para verificar o efeito da granulometria do milho das dietas associada à área por animal e categorias de sexo, nas baias, sobre o desempenho e a incidência de lesões gástricas dos animais nas fases de crescimento e crescimento-terminação, foram estudados os seguintes niveis de cada fator:

Granulometria (GRAN)

$1=$ milho moido em moinho de martelo com peneira de $2,5 \mathrm{~mm}$, o que determinou um módulo de finura (MF) de 2,38 e um diâmetro geométrico médio das partículas (DGM) de $542 \mu \mathrm{m}$.

$2=$ milho moido em moinho de martelo com peneira de $10,0 \mathrm{~mm}$, o que determinou um módulo de finura (MF) de 3,26 e um diâmetro geométrico médio das partículas (DGM) de $998 \mu \mathrm{m}$. 
Área por animal (ÁREA) ou tamanho de grupo

$$
\begin{aligned}
& 1=0,64 \mathrm{~m}^{2} / \text { animal }\left(10 \text { animais } / \text { baia de } 6,4 \mathrm{~m}^{2}\right) \\
& 2=1,07 \mathrm{~m}^{2} / \text { animal }\left(6 \text { animais/baia de } 6,4 \mathrm{~m}^{2}\right) \\
& 3=1,60 \mathrm{~m}^{2} / \text { animal }\left(4 \text { animais/baia de } 6,4 \mathrm{~m}^{2}\right)
\end{aligned}
$$

Devido ao fato de haver um único tamanho de baia, neste experimento há um confundimento entre área por animal e tamanho de grupo.

$$
\begin{aligned}
& \text { Categorias de Sexo (SEXO) } \\
& \quad \begin{array}{l}
1=\text { fềmea } \\
2=\text { macho }
\end{array}
\end{aligned}
$$

Fazendo-se um arranjo fatorial $2 \times 3 \times 2$ (2 GRANs $\times 3$ ÁREAS $\times 2$ SEXOS) obtiveram-se 12 tratamentos experimentais que foram casualizados em quatro blocos completos de tamanho 12 , sendo que o bloco foi uma combinação de sala e dia em que os animais entraram para o experimento. As baias eram de concreto, com área de 6,8 $\mathrm{m}^{2}$, e piso parcialmente ripado. O comedouro, automático e com quatro bocas, tinha uma área de $0,4 \mathrm{~m}^{2}$ e capacidade de $70 \mathrm{~kg}$ de ração. O bebedouro foi do tipo chupeta.

O periodo experimental foi de 87 dias, sendo 45 dias para a fase de crescimento e 42 dias para a fase de terminação. $O$ peso dos animais e o consumo de ração foram registrados sempre na mesma hora da manhã, a partir do início do experimento, a cada 15 dias na fase de crescimento e a cada 14 dias na fase de terminação. Através da diferença entre a quantidade de ração fornecida e as sobras e desperdício, foi medido o consumo de ração dos animais. $\mathrm{O}$ fornecimento de ração e água foi à vontade durante todo o experimento.

Para a obtenção dos diferentes graus de moagem do milho foram utilizados dois tamanhos de peneiras (2,00 mm e 10,0 mm) em um moinho de martelos, com quatro conjuntos de martelos, acionado por um motor trifásico que proporcionava uma rotação de $3700 \mathrm{rpm}$. Foram coletadas amostras $( \pm 1 \mathrm{~kg})$ de milho dos dois tratamentos para a análise granulométrica.

Cada granulometria foi caracterizada segundo o módulo de finura (MF) e o diâmetro geométrico médio (DGM) das partículas do milho. 
A análise granulométrica do milho foi realizada pelo método da peneiração. Para esta análise foi utilizado um conjunto de peneiras padronizadas pela ASSOCIAÇÃO BRASILEIRA DE NORMAS TÉCNICAS (ABNT), Norma MB-7 (1987), a saber, peneiras de 4,00,2,00,1,20,0,60,0,30 e 0,15 mm, e um aparelho vibrador de peneiras "Produtest", equipado com temporizador e reostato. As condições de peneiração foram fixadas em $250 \mathrm{~g}$ de amostra de milho seco $\left(105^{\circ} \mathrm{C}\right.$ por 8 horas), tempo de vibração de 10 minutos e velocidade vibratória de $80 \%$ da capacidade máxima do aparelho. Sob as condições acima, foi obtido o percentual, em peso, de milho retido em cada uma das peneiras e foi determinado a partir daí, o MF e DGM, segundo HENDERSON $\varepsilon$ PERRY (1955). O MF é expresso como um número e é uma indicação da granulometria de uma amostra do alimento. Estes valores variam de 0 a 6 , com o menor número indicando um tamanho de partícula pequeno e o maior número denotanto um tamanho de partícula grande.

As diferentes áreas por animal foram obtidas, mantendo-se em baias de mesmo tamanho $\left(6,8 \mathrm{~m}^{2}-0,4 \mathrm{~m}^{2}\right.$ de área do comedouro $\left.=6,4 \mathrm{~m}^{2}\right)$ diferentes números de animais $\left(4,6\right.$, e 10 animais por baia) o que proporcionou $1,60 \mathrm{~m}^{2}, 1,07 \mathrm{~m}^{2}$ e $0,64 \mathrm{~m}^{2}$ por animal, respectivamente.

As dietas, cuja composição percentual e em nutrientes encontram-se na Tabela 1, foram formuladas à base de milho e farelo de soja, suplementadas com minerais e vitaminas, a partir dos resultados da composição química dos ingredientes e dos valores de energia digestível (ED) extraídos da tabela da EMBRAPA (1991), considerando as exigências nutricionais mínimas dos animais contidas no NATIONAL RESEARCH COUNCIL (1988). As dietas foram homogeneizadas, utilizando-se um misturador vertical.

Para o estudo do efeito dos tratamentos sobre o desempenho dos suínos foram consideradas as variáveis GPD, CRD e CA.

Ao final do experimento, ocasião do abate, todos os suínos foram examinados quanto à incidência de lesão no PE do estômago. O PE do estômago foi analisado macroscopicamente quanto à presença ou ausência de úlcera e hiperqueratose na mucosa gástrica, segundo metodologia descrita em NUWER (1967). Para efeito de análise, considerou-se o estômago como (1) normal, (2) com hiperqueratose do epitélio escamoso (quando o mesmo apresentava-se corrugado e amarelo ou com erosão) e (3) com úlcera (quando o mesmo apresentava-se com úlceras ativas de diferentes proporções e também 
com cicatrizacão). Com relação à lesões gástricas considerou-se que, ao início do experimento, os animais apresentavam as mesmas condições, uma vez que não foi usada metodologia para caracterizar, "in vivo", a situação do estômago e pela aleatorização realizada.

Tabela 1- Composição percentual e em nutrientes das dietas experimentais das fases de crescimento e terminação.

\begin{tabular}{lcc}
\hline & & Fase \\
\cline { 2 - 3 } Ingredientes & Crescimento & Terminação \\
\hline Milho & 79,54 & 81,33 \\
Farelo de soja & 18,00 & 13,67 \\
Fosfato bicálcico & 1,01 & 0,76 \\
Calcário & 0,95 & 1,00 \\
Sal & 0,30 & 0,30 \\
Premix 1,2 & 0,20 & 0,15 \\
Caulim & - & 2,79 \\
\hline Total & 100,00 & 100,00 \\
\hline Nutrientes: & & \\
Proteína bruta (\%) & 15,00 & 13,01 \\
Lisina (\%) & 0,70 & 0,58 \\
Cálcio (\%) & 0,62 & 0,57 \\
Fósforo total (\%) & 0,53 & 0,46 \\
Fósforo disponivel (\%) & 0,30 & 0,24 \\
Energia digestivel (kcal/kg) & 3406 & 3310 \\
\hline \hline
\end{tabular}

${ }^{1}$ Fornecendo por kg de dieta: 1.600 e 1600 UI Vit. A; 200 e 200 UI Vit. D; 16,00 e 13,00 UI Vit. E; 0,56 e 0,56 mg Vit. K; 3,00 e 2,44 mg Vit. $B_{2} ; 1,00$ e 1,00 mg Vit. $B_{6} ; 10,00$ e 5,00 $\mu \mathrm{g}$ Vit. $B_{12} ; 10,00$ e 7,00 mg ác. nicotínico; 8,00 e 7,00 mg ác. pantotênico; 300,00 e 300,00 mg colina; 1,00 e 1,00 mg tiamina; 0,05 e 0,05 mg biotina; 0,30 e 0,30 mg ác. fólico; 60,00 e 40,00 mg Fe; 80,00 e 65,00 mg Zn; 129,00 e 78,00 mg Cu; 2,00 e 2,00 mg Mn; 0,15 e 0,10 mg Se; 0,14 e $0,14 \mathrm{mg} \mathrm{I} ; 125,00$ e 125,00 mg etoxiquim, para as fases de crescimento e terminação, respectivamente.

${ }^{2} \mathrm{O} \mathrm{Cu}$ foi utilizado como promotor de crescimento aos níveis de 125 e $75 \mathrm{mg} / \mathrm{kg}$ de dieta para as fases de crescimento e terminação, respectivamente. 


\subsection{Análise dos dados de desempenho}

As variáveis GPD, CRD e CA foram analisadas segundo o modelo linear longitudinal (ANDRADE \& SINGER, 1986), nas fases de crescimento e crescimento-terminação, como se segue:

$$
\begin{aligned}
& Y_{j i k l m}=\mu+b_{j}+G_{i}+T_{k}+S_{1}+G_{i k}+G_{i l}+T_{k l}+G_{T S}+e_{l i k l}+C_{m}+G_{i m}+T_{k m}+ \\
& \mathrm{SC}_{\mathrm{lm}}+\mathrm{GTC}_{\mathrm{ikm}}+\mathrm{GSC}_{\mathrm{ilm}}+\mathrm{TSC}_{\mathrm{klm}}+\mathrm{GTSC}_{\mathrm{iklm}}+\mathrm{e}_{\mathrm{jiklm}}
\end{aligned}
$$

com:

$$
\begin{array}{ll}
\mathrm{j}=1,2,3,4 & \text { blocos } \\
\mathrm{i}=1,2 & \text { granulometrias } \\
\mathrm{k}=1,2,3 & \text { áreas e/ou tamanhos de grupo } \\
\mathrm{l}=1,2 & \text { sexos } \\
\mathrm{m}=1,2,3 & \text { períodos de avaliação na fase crescimento } \\
\mathrm{m}=1,2,3,4,5,6 & \text { períodos de avaliação na fase crescimento-terminação }
\end{array}
$$

onde:

$Y_{\text {jiklm }}$ é a resposta correspondente ao grupo de animais do bloco j, granulometria i, área k, sexo 1 e condição de avaliação m;

$\mu$ é a média geral da resposta no experimento;

$b_{j}$ é o efeito do bloco j; bloco representa uma combinação de sala e dia em que os animais entraram para o experimento.

$\mathrm{G}_{i}$ é o efeito da granulometria $\mathrm{i}$, sendo que:

$\mathrm{G}_{1}=$ milho moído em moinho de martelo com peneira de 2,5 mm $(M F=2,38$ e $\mathrm{DGM}=542 \mu \mathrm{m})$

$\mathrm{G}_{2}=$ milho moído em moinho de martelo com peneira de $10,0 \mathrm{~mm}(\mathrm{MF}=3,26 \mathrm{e}$ DGM=998 $\mu \mathrm{m})$ 
$\mathrm{T}_{\mathrm{k}}$ é o efeito da área, sendo que:

$$
\begin{aligned}
& \mathrm{T}_{1}=0,64 \mathrm{~m}^{2} / \text { animal }\left(10 \text { animais /baia de } 6,4 \mathrm{~m}^{2}\right. \text { ) } \\
& \mathrm{T}_{2}=1,07 \mathrm{~m}^{2} / \text { animal }\left(6 \text { animais /baia de } 6,4 \mathrm{~m}^{2}\right. \text { ) } \\
& \mathrm{T}_{3}=1,60 \mathrm{~m}^{2} / \text { animal }\left(4 \text { animais /baia de } 6,4 \mathrm{~m}^{2}\right)
\end{aligned}
$$

$S_{1}$ é o efeito de sexo, sendo que:

$$
\begin{aligned}
& S_{1}=\text { fềmea } \\
& S_{2}=\text { macho }
\end{aligned}
$$

$\mathrm{GT}_{\mathrm{ik}}$ é o efeito da interação granulometria i $\mathrm{x}$ área $\mathrm{k}$

$\mathrm{GS}_{\mathrm{il}}$ é o efeito da interação granulometria i x sexo 1

$\mathrm{TS}_{\mathrm{ij}}$ é o efeito da interação área $\mathrm{k} x$ sexo $\mathrm{l}$

GTS $_{\mathrm{ikl}}$ é o efeito da interação tripla granulometria i $\mathrm{x}$ área $\mathrm{k} x$ sexo $\mathrm{l}$

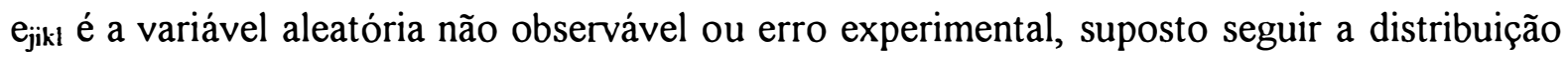
normal de média zero e variância $\sigma_{a}^{2}$. Este é o termo apropriado para testar os efeitos do arranjo fatorial 2 granulometrias $\times 3$ áreas $\times 2$ sexos.

$\mathrm{C}_{\mathrm{m}}$ é o efeito da condição de avaliação, sendo que:

$\mathrm{C}_{1}=$ avaliação da unidades experimentais aos 15 dias após o início do experimento

$\mathrm{C}_{2}=$ avaliação da unidades experimentais aos 30 dias após o início do experimento

$\mathrm{C}_{3}=$ avaliação da unidades experimentais aos 45 dias após o início do experimento

$\mathrm{C}_{4}=$ avaliação da unidades experimentais aos 59 dias após o início do experimento

$\mathrm{C}_{5}=$ avaliação da unidades experimentais aos 73 dias após o início do experimento

$\mathrm{C}_{6}=$ avaliação da unidades experimentais aos 87 dias após o início do experimento

$\mathrm{GC}_{\text {im }}$ é o efeito da interação granulometria i $x$ condição de avaliação $\mathrm{m}$

$\mathrm{TC}_{\mathrm{km}}$ é o efeito da interação área $\mathrm{k} x$ condição de avaliação $\mathrm{m}$

$\mathrm{SC}_{\mathrm{lm}}$ é o efeito da interação sexo $1 \mathrm{x}$ condição de avaliação $\mathrm{m}$

$\mathrm{GTC}_{\mathrm{ikm}}$ é o efeito da interação tripla granulometria i $\mathrm{x}$ área $\mathrm{k} \mathrm{x}$ condição de avaliação $\mathrm{m}$ $\mathrm{GSC}_{\text {ilm }}$ é o efeito da interação tripla granulometria i $x$ sexo $1 \times$ condição de avaliação $m$ $\mathrm{TSC}_{\mathrm{klm}}$ é o efeito da interação tripla área $\mathrm{k} x$ sexo $1 \mathrm{x}$ condição de avaliação $\mathrm{m}$

GTSC $_{i k l m}$ é o efeito da interação de quarto grau entre granulometria $\mathrm{i} x$ área $\mathrm{k} x$ condição de avaliação $\mathrm{m} x$ sexo 1 
$e_{j i k l m}$ é a variável aleatória não observável, suposto seguir a distribuição normal de média zero e variância $\sigma_{\mathrm{b}}^{2}$. Este é o termo apropriado para testar o efeito da condição de avaliação e as interações entre as condições de avaliação e o fatorial 2 granulometrias $x$ 3 áreas $\mathrm{x} 2$ sexos.

A estatística $\mathrm{F}$ foi usada para testar as hipóteses formuladas e o teste $\mathrm{t}$ protegido foi usado nas comparações de médias, conforme o procedimento GLM do SAS (1985).

\subsection{Análise da lesão gástrica no animal}

A variável lesão gástrica foi analisada segundo o modelo de análise de variância discreta, dado por:

$Y_{i j k l}=G_{i}+T_{j}+S_{k}+G T_{i j}+G S_{i k}+T S_{j k}+G T S_{i j k}+e_{i j k l}$

com:

$$
\begin{aligned}
\mathrm{i}=1,2 \quad \text { (granulometrias) } \\
\mathrm{j}=1,2,3 \quad \text { (áreas e/ou tamanhos de grupo) } \\
\mathrm{k}=1,2 \quad \text { (sexos) } \\
1=\text { refere-se às categorias, sendo: } \\
1=1 \text { ausência de lesão } \\
1=2 \text { presença de hiperqueratose } \\
1=3 \text { presença de úlcera }
\end{aligned}
$$

onde:

$Y_{\mathrm{ijkl}}$ é a frequência (\%) correspondente aos animais classificados na granulometria $\mathrm{i}$, área $\mathrm{j}$, sexo k e categoria l;

$\mathrm{G}_{\mathrm{i}}$ é o efeito da granulometria $\mathrm{i}$;

$\mathrm{T}_{\mathrm{j}}$ é o efeito da área $\mathrm{j}$;

$\mathrm{S}_{\mathrm{k}}$ é o efeito de sexo;

$\mathrm{GT}_{\mathrm{ij}}$ é o efeito da interação granulometria i $x$ área $j$

$\mathrm{GS}_{\mathrm{ik}}$ é o efeito da interação granulometria i x sexo k; 
$\mathrm{TS}_{\mathrm{jk}}$ é o efeito da interação área $\mathrm{j}$ x sexo $\mathrm{k}$; GTS $_{\mathrm{ijk}}$ é o efeito da interação tripla granulometria i $x$ área $\mathrm{j}$ x sexo $\mathrm{k}$; $\mathrm{e}_{\mathrm{ijkl}}$ é a variável aleatória não observável, suposto seguir a distribuição trinomial com média e variância conhecidas, que depende do número de observações avaliadas.

A estatística usada para o teste de hipóteses foi o quiquadrado estimado pelo método da razão de verossimilhança, conforme o procedimento CATMOD do SAS (1985).

\subsection{Associação dos tratamentos (granulometria e área por animal) e lesão gástrica sobre o desempenho animal}

Com a finalidade de complementar a análise do efeito das lesões gástricas (hiperqueratose e úlcera) sobre o GPD, foi usado o seguinte modelo para o período total do experimento:

$Y_{i j k l}=\mu+G_{i}+T_{j}+L_{k}+G T_{i j}+G_{i k}+T L_{j k}+G T L_{i j k}+e_{i j k l}$

com:

$$
\begin{aligned}
& \mathrm{i}=1,2 \quad \text { (granulometrias) } \\
& \mathrm{j}=1,2,3 \quad \text { (áreas e/ou tamanhos de grupo) } \\
& \mathrm{k}=\text { refere-se às categorias, sendo: } \\
& \mathrm{k}=1 \text { ausência de lesão } \\
& \mathrm{k}=2 \text { presença de hiperqueratose } \\
& \mathrm{k}=3 \text { presença de úlcera } \\
& \mathrm{l}=1,2, \ldots, \mathrm{n}_{\mathrm{ijk}}
\end{aligned}
$$

onde:

$\mathrm{Y}_{\mathrm{ijkl}}$ é o ganho de peso médio diário correspondente ao animal l, pertencente à granulometria $\mathrm{i}$, área j e classificado com nível de lesão k; $\mu$ é o ganho de peso médio no experimento; 
$\mathrm{G}_{\mathrm{i}}$ é o efeito da granulometria $\mathrm{i}$;

$\mathrm{T}_{\mathrm{j}}$ é o efeito da área $\mathrm{j}$;

$\mathrm{L}_{\mathrm{k}}$ é o efeito da lesão $\mathrm{k}$;

$\mathrm{GT}_{\mathrm{ij}}$ é o efeito da interação granulometria i $\mathrm{x}$ área $\mathbf{j}$.

$\mathrm{GL}_{\mathrm{ik}}$ é o efeito da interação granulometria i x lesão k.

$\mathrm{TL}_{\mathrm{ij}}$ é o efeito da interação área $\mathrm{j} x$ lesão $\mathrm{k}$.

GTL $_{\mathrm{ijk}}$ é o efeito da interação tripla granulometria i x área j x lesão k.

$\mathrm{e}_{\mathrm{ijkl}}$ é a variável aleatória não observável, suposto seguir a distribuição normal de média zero e variância constante.

Devido ao reduzido número de observações, para completar todas as caselas, o efeito de sexo não foi considerado neste modelo.

A estatística usada para o teste de hipóteses foi o teste $F$, conforme o procedimento GLM do SAS (1985). 


\section{RESULTADOS E DISCUSSÃO}

\subsection{Variáveis de desempenho}

A análise de variância longitudinal para as variáveis GPD, CRD e CA encontram-se nas Tabelas 4 a 9 do Apêndice e as médias estimadas, na Tabela 10 do Apêndice.

Não houve de interação $(P=0,113)$ entre os fatores granulometria, área e sexo, para as variáveis estudadas. Isto indica, portanto, que o desempenho de suínos em crescimento e terminação é afetado independentemente por esses fatores. Esses resultados são concordantes com os de JENSEN et alii (1973) e WALKER (1989), que também não observaram qualquer interação entre sexo e área por animal, o que demonstra que machos castrados e fêmeas respondem similarmente à disponibilidade de área por animal.

Verificou-se, para todas as variáveis, um efeito altamente significativo $(\mathrm{P}=0,001)$ entre os períodos de avaliação, indicando, de modo geral, um crescimento na resposta. Isto não se verificou completamente no período dos 16 aos 30 dias de experimento, em que, embora não significativo ( $P>0,05)$, houve um decréscimo no GPD em relação aos primeiros 15 dias, conforme ilustra a Figura 2.

Foi observado interação entre granulometria, sexo e períodos de avaliação apenas para o $\mathrm{CRD}$, sendo que a interação granulometria $\mathrm{x}$ período de avaliação foi significativa $(P=0,034)$ nas duas fases estudadas e a interação sexo $x$ período de avaliação $(\mathrm{P}=0,008)$ na fase crescimento-terminação. 
Houve um efeito significativo $(\mathrm{P}=0,051)$ da granulometria em todas as variáveis estudadas e fases do animal (Tabelas 4 a 9 do Apêndice). Considerando-se as avaliações resumidas, das fases de crescimento e crescimento-terminação, verificou-se que o desempenho foi melhor para a granulometria 2,5 mm, conforme ilustram as Figuras 1, 2 e 3 e Tabelas 11 e 12 do Apêndice.

Observa-se nas Figuras 1, 2 e 3 que, durante a fase de crescimento e período total o milho moido em peneiras de $2,5 \mathrm{~mm}(\mathrm{MF}=2,38$ e $\mathrm{DGM}=542 \mu \mathrm{m})$ proporcionou maior GPD $(\mathrm{P}<0,050)$, CRD $(\mathrm{P}<0,050)$ e melhor $\mathrm{CA}(\mathrm{P}<0,050)$, quando comparado com milho moido em peneiras de $10,0 \mathrm{~mm}(\mathrm{MF}=3,26$ e $\mathrm{DGM}=998 \mu \mathrm{m})$, indicando que os suínos nas fases de crescimento e terminação aproveitam melhor o alimento quando este é fornecido com diâmetro das partículas menores. Este efeito é explicado pela melhor digestibilidade dos alimentos finamente moídos e, efetivamente, IVAN et alii (1974), LIMA et alii (1990) e ZANOTTO (1992), estudando diferentes alimentos, concluíram que tamanhos menores de partículas proporcionaram maior digestibilidade dos nutrientes. Resultados similares foram encontrados por TRIVELIN et alii (1969), LAWRENCE (1972) e HEDDE et alii (1985). ZANOTTO (1992) não observou efeito significativo $(P>0,05)$ da granulometria do milho sobre o GPD mas detectou menor CRD e melhor CA para granulometrias menores. Por outro lado, MAHAN et alii (1966), REIMANN et alii (1968), HSU et alii (1985) e YANG et alii (1988), não observaram qualquer efeito do grau de moagem do milho no desempenho de suinos em crescimento e terminação. Essa divergência de resultados pode ser explicada pela possivel interação das granulometrias com outros fatores, tais como, grau de dureza e pulverulência do grão. 


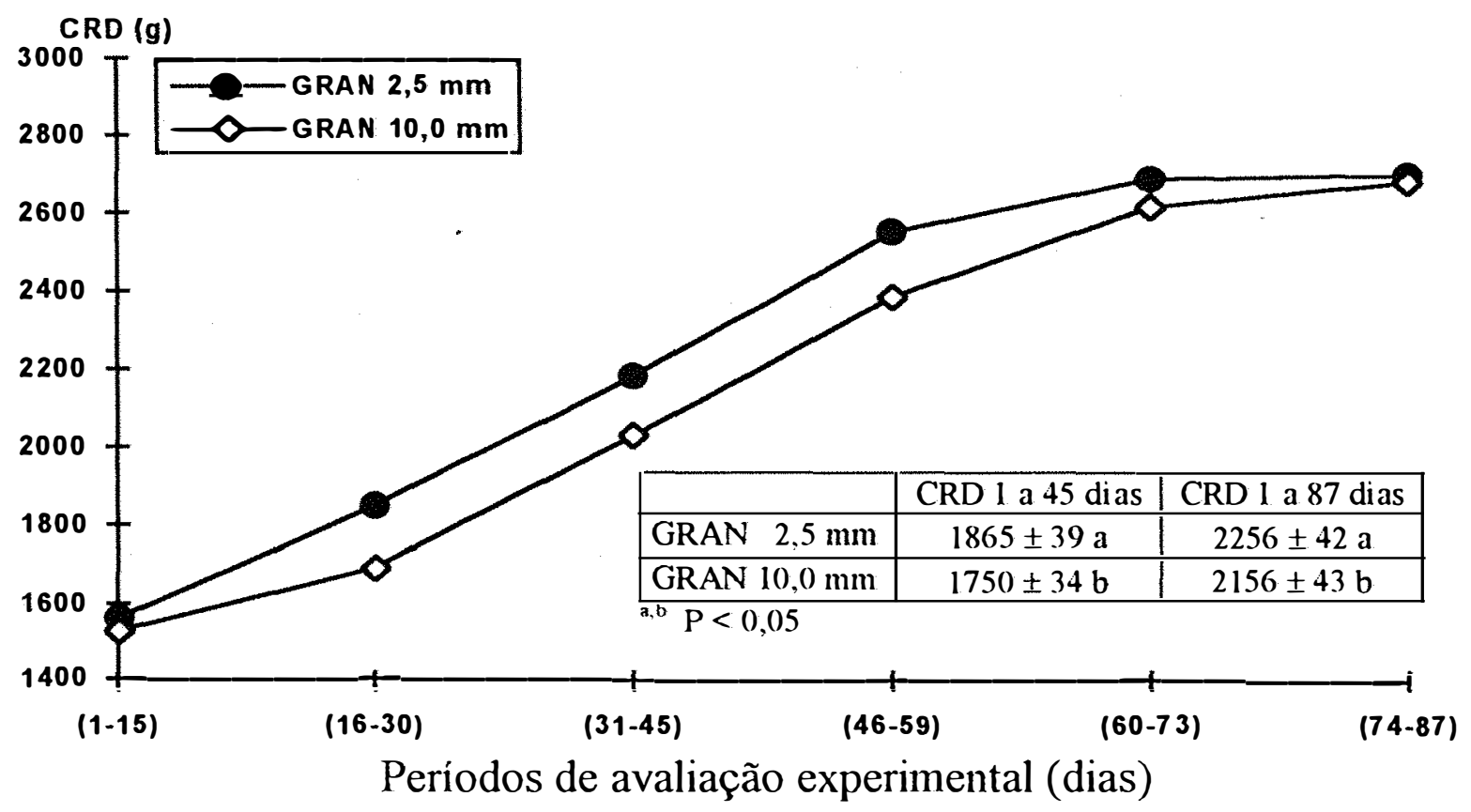

Figura 1 - Efeito da granulometria do milho da dieta sobre o consumo de ração diário (CRD) nas fases de crescimento ( 1 a 45 dias) e crescimento-terminação (1 a 87 dias).

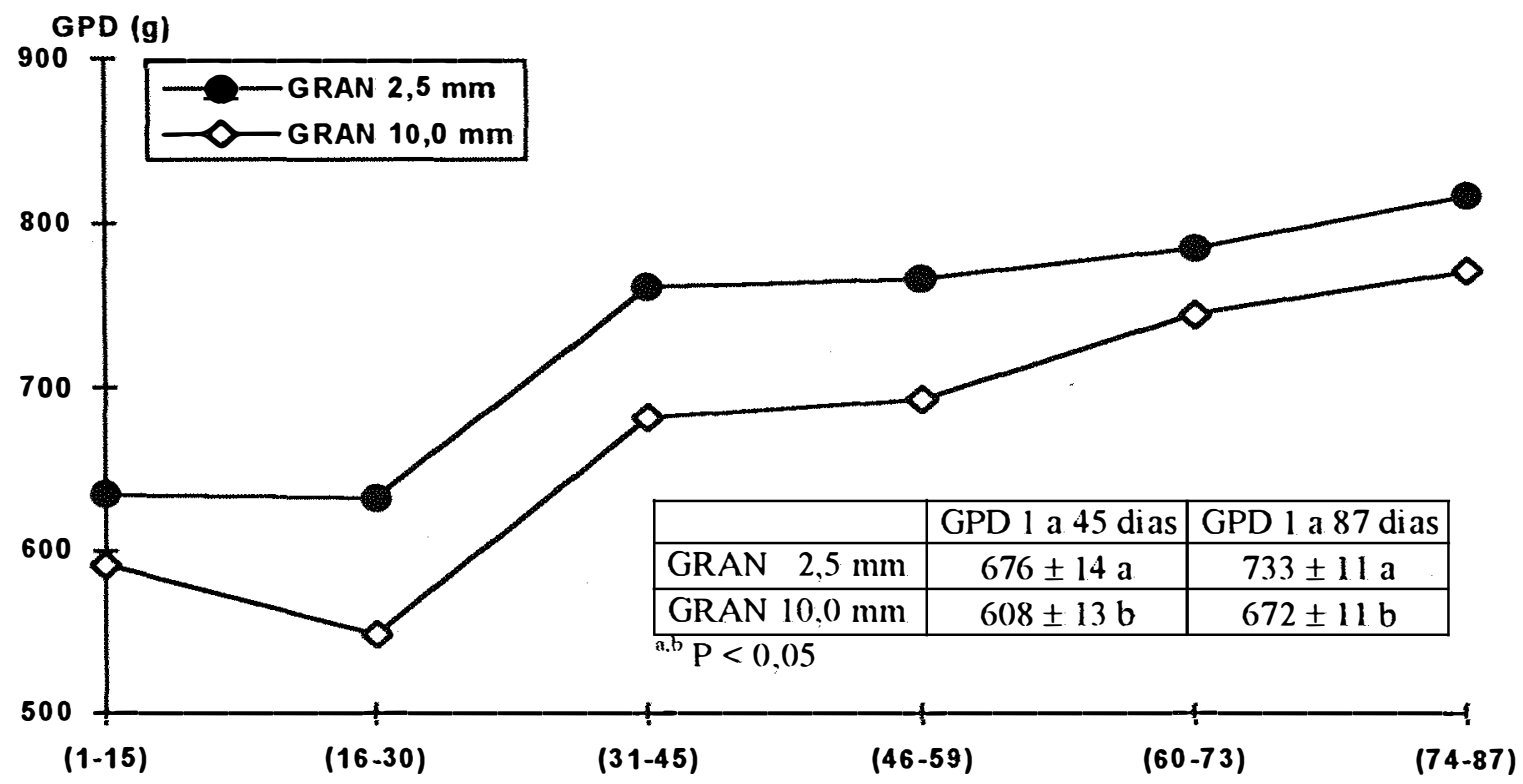

Períodos de avaliação experimental (dias)

Figura 2 - Efeito da granulometria do milho da dieta sobre o ganho de peso diário (GPD) nas fases de crescimento (1 a 45 dias) e crescimento-terminação ( 1 a 87 dias). 


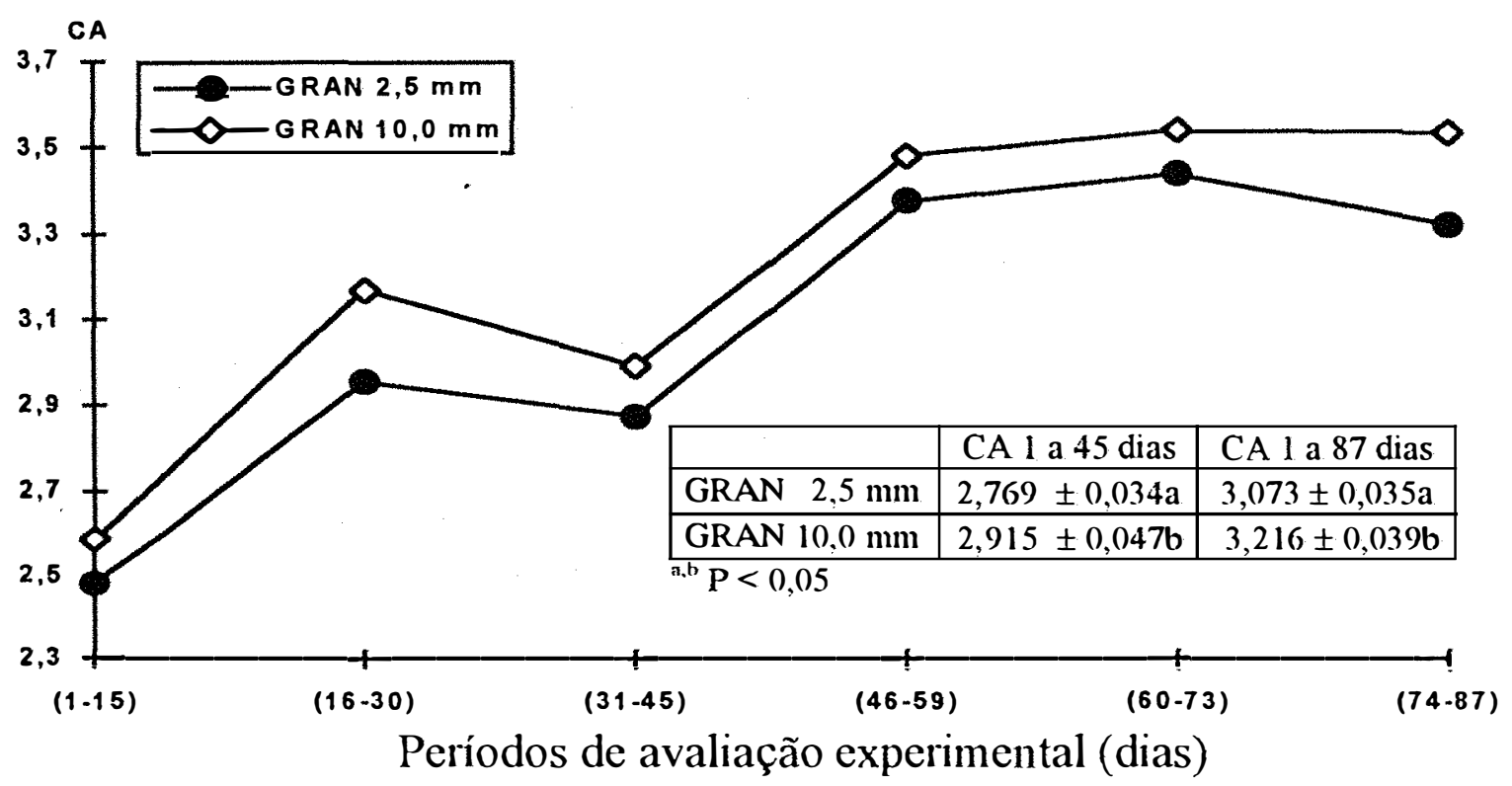

Figura 3 - Efeito da granulometria do milho da dieta sobre a conversão alimentar (CA) nas fases de crescimento ( 1 a 45 dias) e crescimento-terminação ( 1 a 87 dias).

Tanto o GPD como o CRD foram influenciados $(\mathrm{P}=0,091)$ pela área por animal nas fases de crescimento e crescimento-terminação (Tabelas 4, 5, 7 e 8 do Apêndice) e não foi provado efeito $(\mathrm{P}=0,164)$ para a $\mathrm{CA}$ no período total do experimento (Tabela 9 do Apêndice), indicando que a medida em que proporcionou-se uma maior área disponível por animal, durante o período total do experimento, os suínos consumiram mais ração e ganharam peso mais rápido, porém sem influenciar a $\mathrm{CA}$.

Observa-se pelas Tabelas 4 a 9 do Apêndice, que não houve interação entre área e período de avaliação para qualquer variável de desempenho considerada.

Com relação à área por animal, na fase de crescimento o CRD $(\mathrm{P}=0,030)$ e GPD $(\mathrm{P}=0,011)$ foram maiores e a $\mathrm{CA}$ foi melhor $(\mathrm{P}=0,091)$ e, no período total o GPD foi maior $(\mathrm{P}=0,021)$ e a $\mathrm{CA}$ foi melhor $(\mathrm{P}=0,164)$ nos animais submetidos a $1,07 \mathrm{~m}^{2}$ do que em $0,64 \mathrm{~m}^{2}$. Além disto, os resultados obtidos com a área intermediária $\left(1,07 \mathrm{~m}^{2}\right)$ foram semelhantes a maior área $\left(1,60 \mathrm{~m}^{2}\right)$, conforme ilustram as Figuras 4,5 e 6 e Tabelas 11 e 12. Este resultado corrobora com os de JENSEN et alii (1973), no caso de suínos criados em piso parcialmente ripado, BRYANT $\varepsilon$ EUBANK (1974) e KORNEGAY $\varepsilon$ NOTTER (1984). MOREIRA (1981), da mesma forma, observou queda no GPD e no CRD 
e efeito linear decrescente na EA com a restrição do espaço. GELBACH et alii (1966) observaram aumento no GPD com o aumento na área disponível para suínos na fase de crescimento mas não detectaram o mesmo efeito na fase de terminação. MEUNIERSALAUN et alii (1987) não observaram efeito da restricão da área para o animal sobre o CRD. HSIA \& LU (1985) não observaram efeito do mesmo fator sobre o GPD e CRD em suínos testados pesando de 18,7 a $80,9 \mathrm{~kg}$.

Uma pior resposta no desempenho de suínos submetidos à restrição de espaço poderia ser esperada, devido aos problemas ocasionados na modificação do ambiente e no comportamento dos animais (BRYANT \& EUBANK, 1974). EUBANK (1972) cita como possíveis causas desta pior resposta (1) a elevação da temperatura ao redor dos animais, forçando a queda no consumo de alimentos, (2) o estabelecimento de doenças subclínicas, o que prejudica a eficiência de utilização de alimentos e, (3) a modificação no ambiente social dos animais aglomerados.

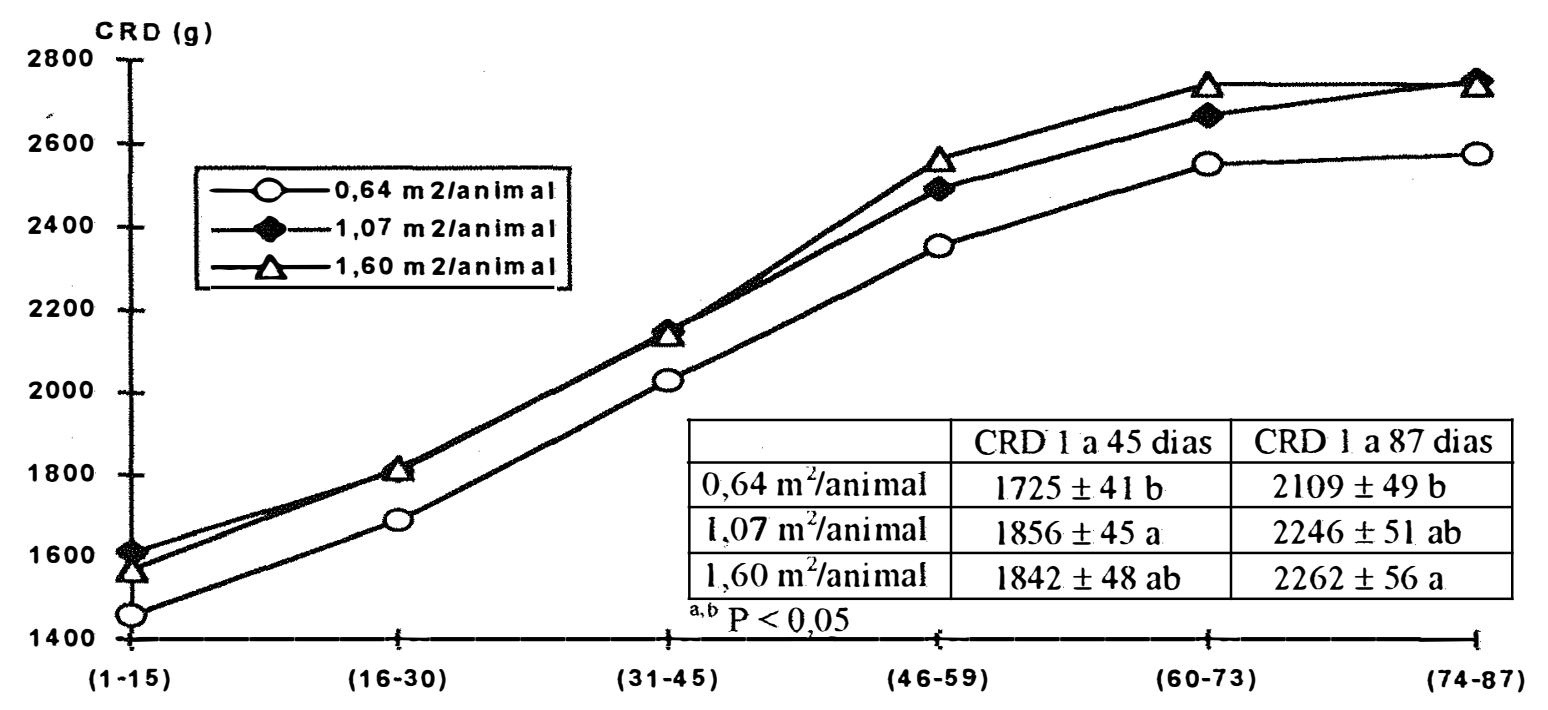

Períodos de avaliação experimental (dias)

Figura 4 - Efeito da área por animal sobre o consumo de ração diário (CRD) nas fases de crescimento (1 a 45 dias) e crescimento-terminação (1 a 87 dias). 


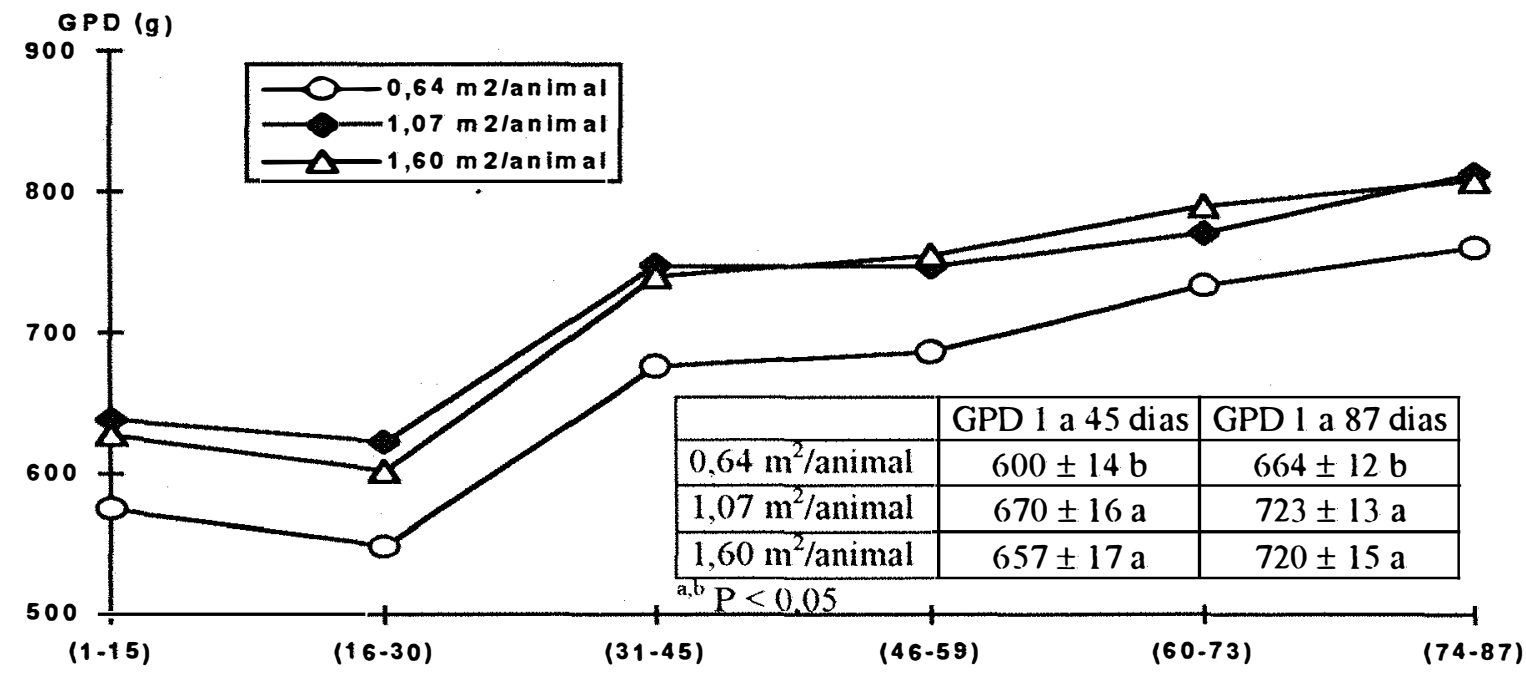

Períodos de avaliação experimental (dias)

Figura 5 - Efeito da área por animal sobre o ganho de peso diário (GPD) nas fases de crescimento ( 1 a 45 dias) e crescimento-terminação (1 a 87 dias).

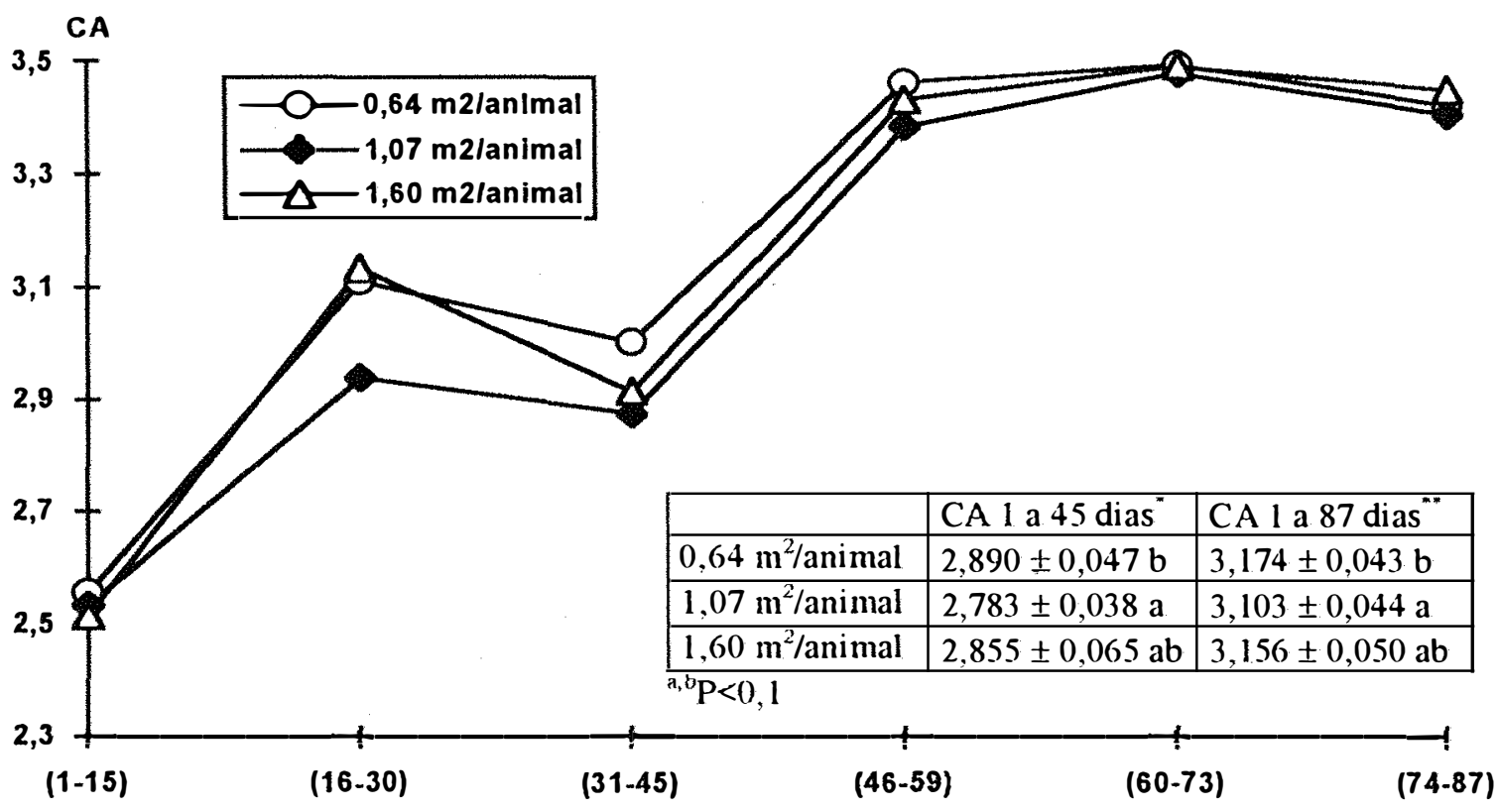

Períodos de avaliação experimental (dias)

Figura 6 - Efeito da área por animal sobre a conversão alimentar (CA) nas fases de crescimento ( 1 a 45 dias) e crescimento-terminação ( 1 a 87 dias).

Com relação ao fator sexo, na fase de crescimento, foi detectado efeito para as variáveis $\mathrm{CRD}(\mathrm{P}=0,023)$ e $\mathrm{GPD}(\mathrm{P}=0,098)$ enquanto que para $\mathrm{CA}$ não foi 
detectado efeito $(\mathrm{P}=0,402)$. $\mathrm{Na}$ fase de crescimento-terminação foi observado efeito $(\mathrm{P}=0,038)$ para todas as variáveis estudadas, indicando que machos castrados tiveram desempenho produtivo diferenciado das fêmeas durante o periodo experimental.

Verificou-se que o ganho de peso e o consumo de ração foram significativamente maiores $(\mathrm{P}<0,05)$ para os machos castrados que para as fêmeas durante todo o período experimental, conforme ilustram as Figuras 7 e 8 e Tabelas 11 e 12 . Observou-se também que a diferença de CRD e de GPD (Figuras 7 e 8 , respectivamente) tende a aumentar à medida que os animais crescem.

Pela Figura 9 observa-se que a CA foi melhor nas fêmeas do que nos machos castrados no período total. Esses resultados são concordantes com os de JENSEN (1973), MAHAN $\varepsilon$ GERBER (1985), HSIA $\varepsilon$ LU (1985), CASTELL et alii (1986) e SCHIRVEL $\varepsilon$ HANSET (1988). Contudo, são discordantes daqueles encontrados por KUAN $\varepsilon$ MARK (1983) e BERESKIN $\varepsilon$ STEELE (1988).

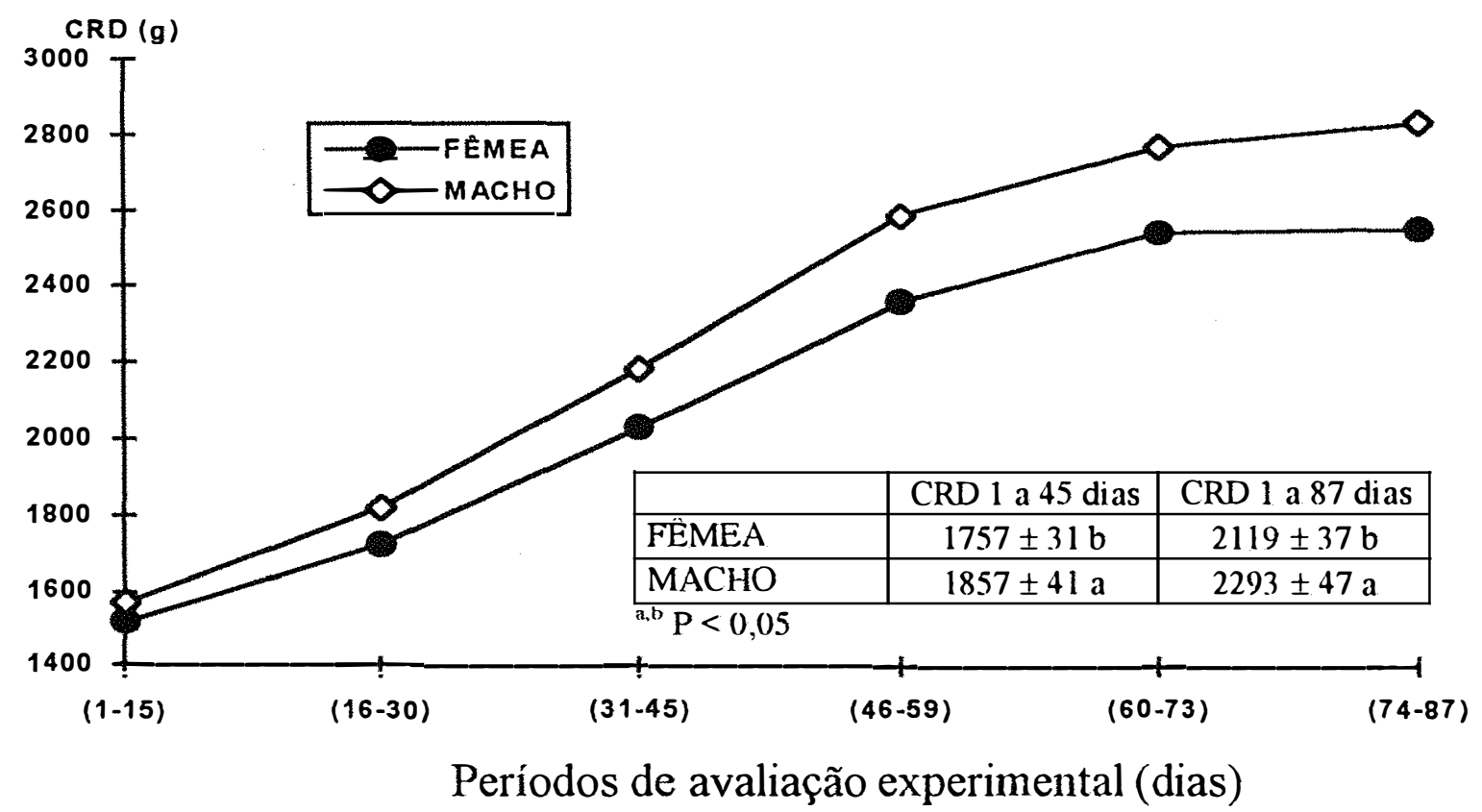

Figura 7- Efeito do sexo sobre o consumo de ração diário (CRD) nas fases de crescimento ( 1 a 45 dias) e crescimento-terminação ( 1 a 87 dias). 


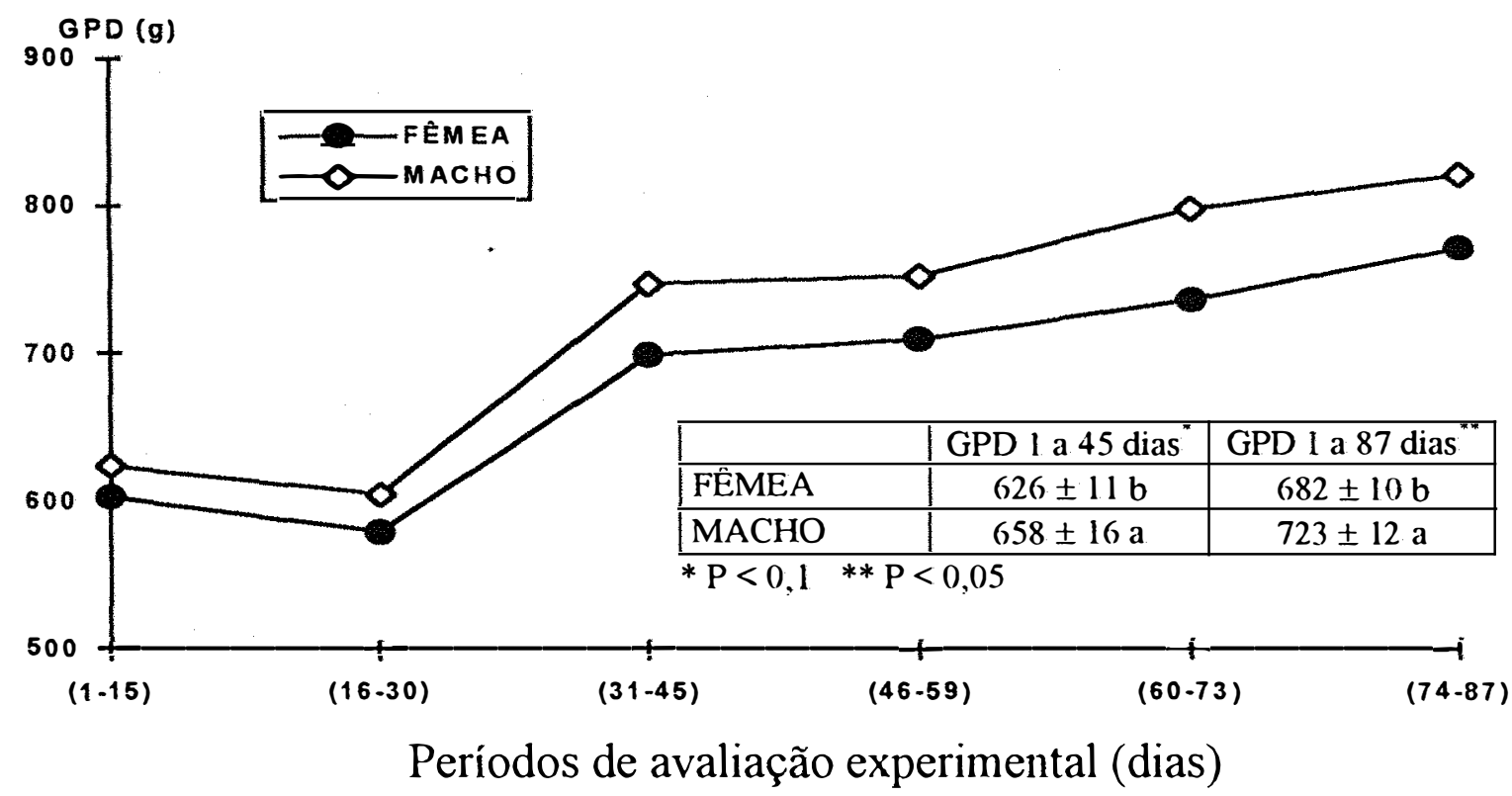

Figura 8 - Efeito do sexo sobre o ganho de peso diário (GPD) nas fases de crescimento ( 1 a 45 dias) e crescimento-terminação (1 a 87 dias).

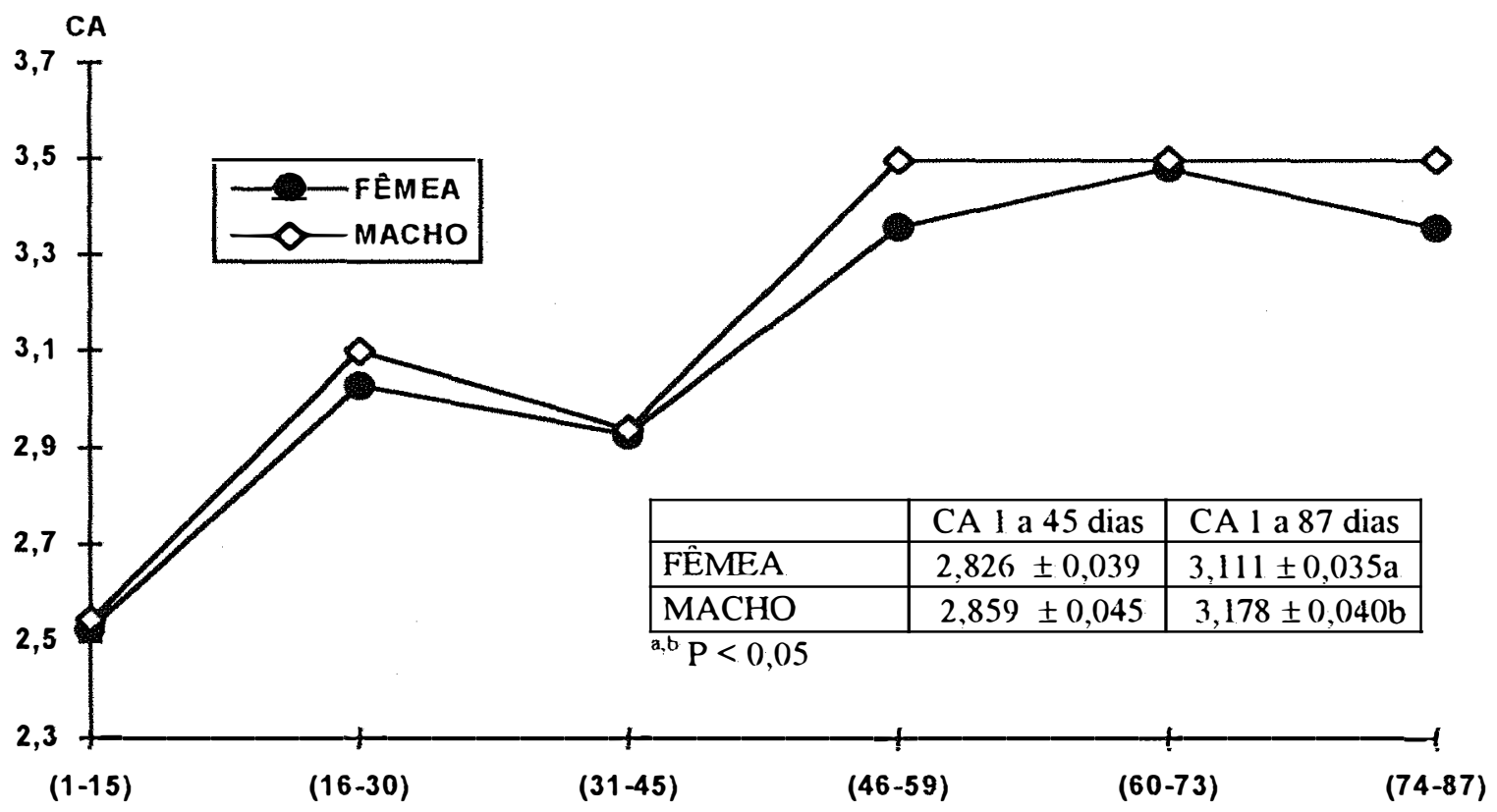

Períodos de avaliação experimental (dias)

Figura 9 - Efeito do sexo sobre a conversão alimentar (CA) nas fases de crescimento ( 1 a 45 dias) e crescimento-terminação ( 1 a 87 dias). 


\subsection{Lesão gástrica}

Exceto a região esofagogástrica (PE do estômago), nas regiões cárdica, fúndica e pilórica do. estômago dos suínos examinadas macroscopicamente ao final do experimento (ocasião do abate), não foi observado qualquer tipo de alteração patológica. Esta constatação evidencia claramente que a granulometria do milho das dietas bem como os demais fatores estudados não influenciou a aparência da mucosa gástrica nas referidas regiões. O fato de que as alterações e/ou lesões estomacais dos suínos prevalecem no PE do estômago foi também demonstrado nos estudos de MUGGENBURG et alii (1964), TAMÁS et alii (1983), KIRCHGESSNER et alii (1985), CIACCI et alii (1991), O'BRIEN (1992) e ZANOTTO (1992).

É provável que as lesões estomacais dos suínos predominam no $\mathrm{PE}$ devido, principalmente, à ausência de muco nesta região e ao tipo de epitélio, o que o torna relativamente desprotegido contra as ações digestivas do $\mathrm{HCl}$ e da enzima pepsina, que se encontram presentes no estômago.

As freqüências estimadas das lesões gástricas (hiperqueratose e úlcera), bem como a análise de variância discreta encontram-se nas Tabelas 13 e 14, do Apêndice, respectivamente.

$\mathrm{Na}$ Tabela 14 verifica-se que houve um efeito altamente significativo da granulometria $(\mathrm{P}=0,001)$ e efeito do $\operatorname{sexo}(\mathrm{P}=0,079)$ sobre a incidência de lesão gástrica. Observou-se que a granulometria $2,5 \mathrm{~mm}$ proporcionou maior incidência de animais com hiperqueratose e úlcera em relação à granulometria $10,0 \mathrm{~mm}$, conforme ilustra a Figura 10 , demonstrando claramente o efeito marcante que a moagem fina do milho exerce no desenvolvimento das alterações epiteliais do PE do estômago dos suínos. Efeitos similares da moagem fina de vários alimentos foram também demonstrados por CURTIN et alii (1963), REIMANN et alii (1968), POTKINS (1989), CABRERA et alii (1994) e STRAW et alii (1994). ZANOTTO (1992) observou maior incidência de hiperqueratose com o uso de granulometria do milho mais fina, porém sem o desenvolvimento de úlceras. Por outro lado, WU et alii (1986, 1987 e 1989) e LIN et alii (1988) não observaram efeito da moagem do alimento sobre a ocorrência de úlcera gástrica. 
Cabe aqui uma discussão sobre o efeito da granulometria fina sobre o aumento na ocorrência de lesões gástricas no PE do estômago. É fato que o uso de milho finamente moído provoca maior frequência de hiperqueratose e úlcera no PE do estômago de suínos em crescimento e terminação, porém isto não impede que os mesmos apresentem maiores GPD e CRD, como também melhor $\mathrm{CA}$, do que suínos que recebem dietas com granulometrias do milho mais grossas, conforme os resultados deste trabalho. Logo, ocorre uma maior taxa de aproveitamento do alimento, o que pode ser traduzido como maior digestibilidade do alimento, conforme demonstram trabalhos de IVAN et alii (1974), LIMA et alii (1990) e ZANOTTO et alii (1992).

Concomitantemente à maior área de superficie de exposição às ações das secreções digestivas, o que é proporcionado pela redução no tamanho da partícula dos alimentos (grãos finamente moídos), possivelmente, ocorre maior produção de $\mathrm{HCl}$ e maior atividade da pepsina, aumentando a quantidade destas secreções digestivas no estômago, tornando-o mais ácido (REIMANN et alii, 1968; MAXWELL et alii, 1970; SIMMONSSON $\varepsilon$ BJÖRKLUND, 1978 citados por O'BRIEN, 1992). REIMANN et alii (1968) indicaram que o efeito do tamanho da partícula da dieta sobre as lesões gástricas foram causadas por uma alteração na atividade da pepsina, fluidez dos conteúdos estomacais, ou ambos, e não por uma diminuição na secreção de muco ou aumento na secreção ácida. Aliado a isto poderia estar associado um maior consumo de água pelos animais que recebem alimentos com granulometrias mais finas, uma vez que o alimento manter-se-ia mais seco, ocorrendo, portanto, maior fluidez do conteúdo estomacal. Esta maior fluidez proporcionaria um contato mais freqüente das secreções digestivas com o PE do estômago, determinando maior incidência de lesão neste local, uma vez que o mesmo é relativamente desprotegido, por não apresentar glândulas de muco e pela própria característica de ser um epitélio escamoso estratificado (REIMANN et alii, 1968).

Embora não tenha sido verificado diferença $(\mathrm{P}=0,336)$ para área por animal, através da Figura 11 pode-se observar que a frequência de animais com úlcera é maior com área média, ou seja 17,6, 28,7 e 18,5\%, para área de $0,64 \mathrm{~m}^{2}, 1,07 \mathrm{~m}^{2}$ e 1,60 m², respectivamente. 
Pela Figura 12 pode-se observar que a diferença significativa $(\mathrm{P}=0,079)$ entre sexos é causada pela maior incidência de úlcera nos machos $(22,8 \%$ vs $13,2 \%)$.

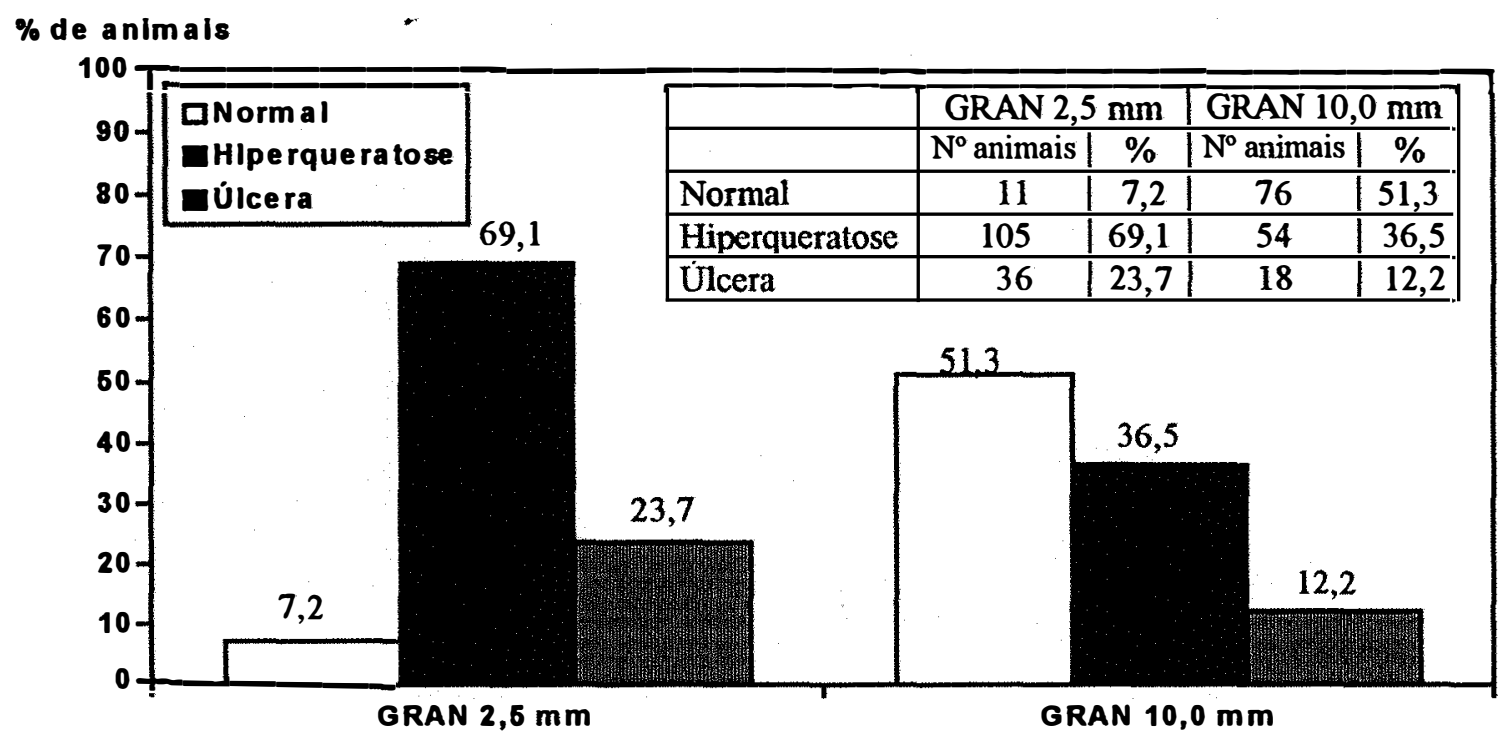

Figura 10 - Efeito da granulometria do milho sobre a incidência de lesões esôfago-gástricas, após 87 dias de fornecimento das dietas experimentais.

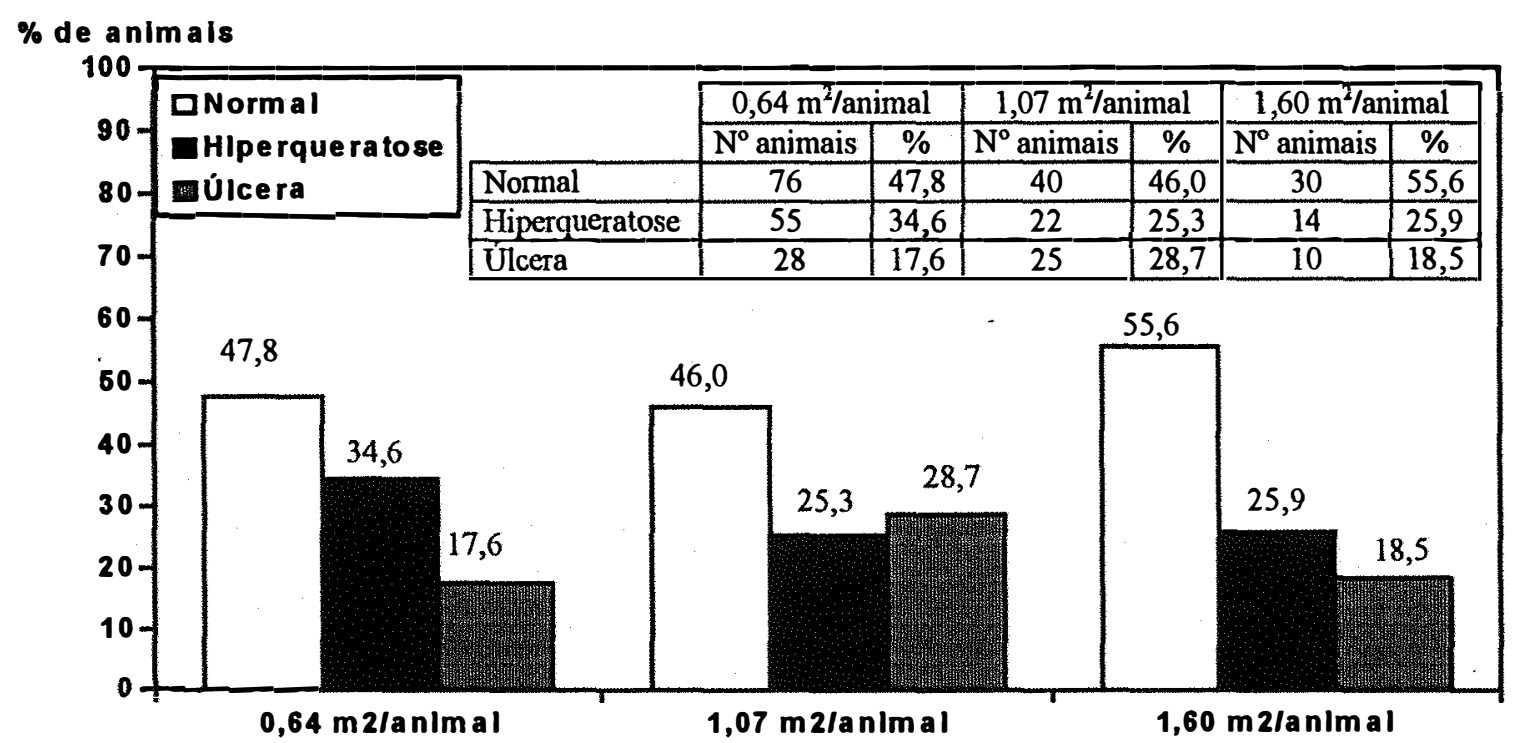

Figura 11 - Efeito da área por animal sobre a incidência de lesões esôfago-gástricas, após 87 dias de aplicação dos tratamentos experimentais. 


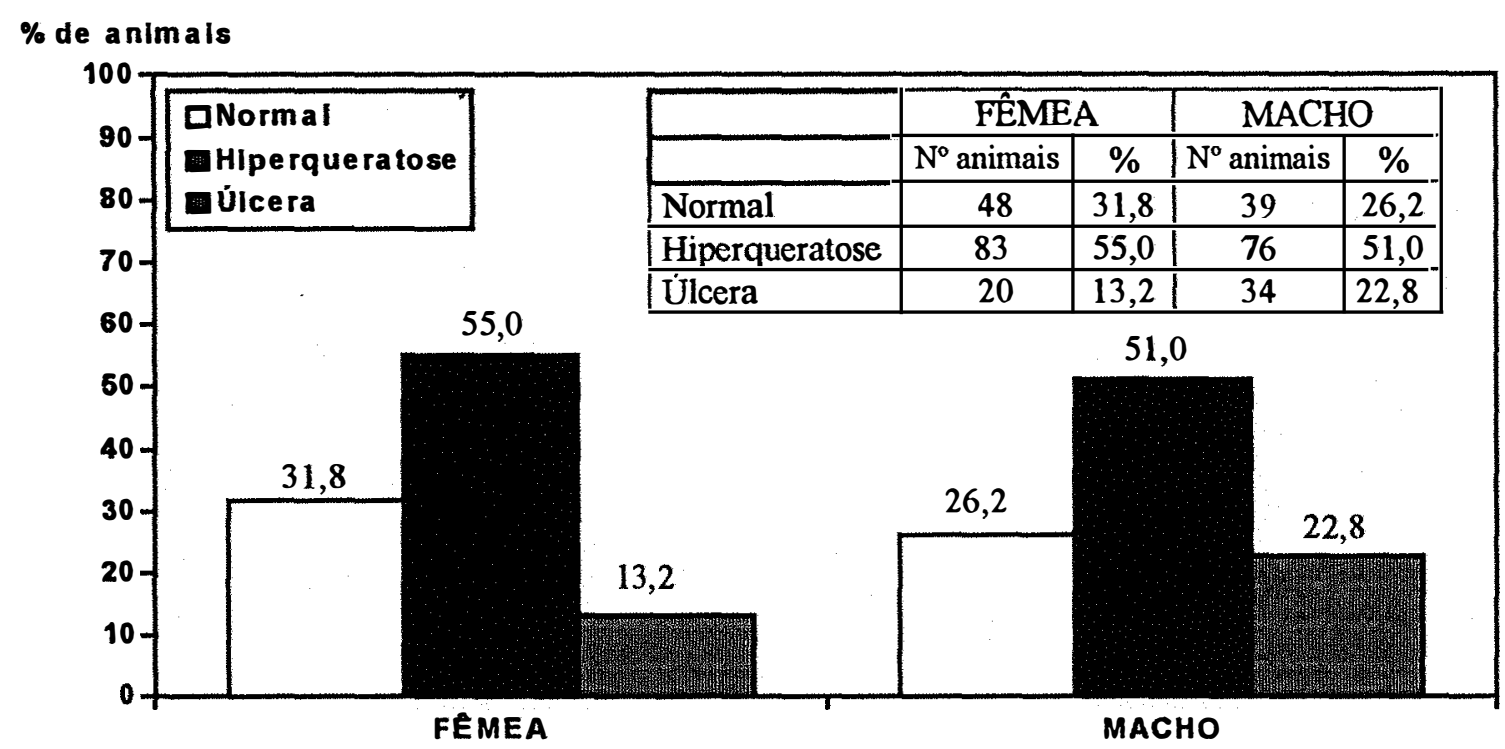

Figura 12 - Efeito do sexo sobre a incidência de lesões esôfago-gástricas, após 87 dias de aplicação dos tratamentos experimentais.

\subsection{Associação dos tratamentos (granulometria e área por animal) e lesão gástrica sobre o desempenho animal}

Os resultados das análises encontram-se.nas Tabelas 15, 16, 17 e 20, do Apêndice.

$\mathrm{Na}$ Tabela 20 observa-se uma interação significativa entre lesão e granulometria $(\mathrm{P}=0,024)$. Desdobrando-se a interação lesão $x$ granulometria (Tabela 2), verifica-se que a diferença no GPD $(\mathrm{P}<0,05)$ observada nos animais que receberam as rações com diferentes granulometrias ocorreu apenas naqueles grupos de animais com hiperqueratose; neste caso a granulometria $2,5 \mathrm{~mm}$ proporcionou 105 gramas de ganho de peso a mais do que com 10,0 mm. Comparando-se os ganhos de peso dos animais classificados nos diferentes grupos de lesão dentro de cada granulometria, observa-se efeito apenas na granulometria $2,5 \mathrm{~mm}$, sendo que os animais com hiperqueratose tiveram um 
melhor ganho de peso em relação ao grupo de animais normais e com úlcera, conforme ilustrado na Figura 13.

Não ocorreu interação lesão $x$ área por animal $(\mathrm{P}=0,528)$ e nem efeito de área por animal ( $\mathrm{P}=0,293)$ sobre o GPD (Tabela 20 do apêndice). Muito embora este resultado seja comum na literatura (MUGGENBURG et alii, 1967; HANDLIN et alii, 1972; MOREIRA, 1981), era de se esperar que a restrição de área tivesse efeito sobre a incidência de lesão gástrica pelos fatores estressantes que ocasiona, tais como, superlotação (MUGGENBURG et alii, 1967), aumento da temperatura ao redor dos animais e modificação do ambiente social, provocando encontros agonísticos mais freqüentes e canibalismo (EWBANK, 1972). BARKER $\varepsilon$ VAN DREUMEL (1985) também citam que estes fatores estariam associados à incidência de lesões gástricas.

Em função das considerações citadas acima decidiu-se por desdobrar a interação lesão $x$ área por animal, referente ao GPD, durante todo o período experimental (1 a 87 dias). Os resultados deste desdobramento encontram-se na Tabela 3 e são ilustrados na Figura 14. Na Tabela 3 observa-se que nos animais com úlcera quanto mais reduzida a área por animal maior o reflexo no GPD indo de 731 para $690(-5,6 \%)$ e para $614(16 \%)$ $\mathrm{g} / \mathrm{d}$. A restriçào de área não teve esse efeito $(\mathrm{P}>0,050)$ negativo nos animais com hiperqueratose ou com estômago normal.

Com relação à variável lesão (tabela 19, do apêndice), independentemente das demais fontes de variação, verificou-se que animais com úlcera tiveram um ganho de peso diário de $665 \mathrm{~g}$, enquanto que animais com hiperqueratose tiveram um ganho de $724 \mathrm{~g}$.

De maneira geral, observa-se pelos resultados que quando a lesão gástrica foi associada à granulometria e área por animal e quando analisada a variável lesão isoladamente, os animais que apresentavam hiperqueratose no PE do estômago obtiveram um GPD maior que animais com úlcera e não foi detectado diferença no GPD entre suínos com estômagos normais e com úlcera. $\mathrm{O}$ fato da presença de hiperqueratose no $\mathrm{PE}$ do estômago de suínos em crescimento e terminação resultar em melhor GPD não encontra suporte na literatura consultada e, para esta ocorrência não foi encontrada uma explicação plausível, necessitando de pesquisas futuras para elucidá-la. 
Tabela 2 - Efeito da granulometria (Gran) associada a lesões esôfago-gástricas sobre o ganho de peso diário (GPD), em gramas (g), na fase crescimento-terminação.

\begin{tabular}{|c|c|c|c|}
\hline \multirow{3}{*}{ Fator } & \multicolumn{3}{|c|}{ Região esôfago-gástrica } \\
\hline & Normal & Hipergueratose & Úlcera \\
\hline & Média \pm Erro Padrão & Média \pm Erro Padrão & Média \pm Erro Padrão \\
\hline Gran $2,5 \mathrm{~mm}$ & $664 \pm 32 \mathrm{Ab}$ & $760 \pm 12 \mathrm{Aa}$ & $661 \pm 24 \mathrm{Ab}$ \\
\hline Gran $10,0 \mathrm{~mm}$ & $683 \pm 14 \mathrm{Aa}$ & $655 \pm 22 \mathrm{Ba}$ & $645 \pm 33 \mathrm{Aa}$ \\
\hline
\end{tabular}

Letras maiúsculas, comparação na coluna.

a,b Letras minúsculas, comparação na linha.

Médias ligadas por letras comuns não diferem pelo teste Tukey $(\mathrm{P}<0,05)$.

Interação granulometria $x$ lesão significativa $(\mathrm{P}=0,024)$

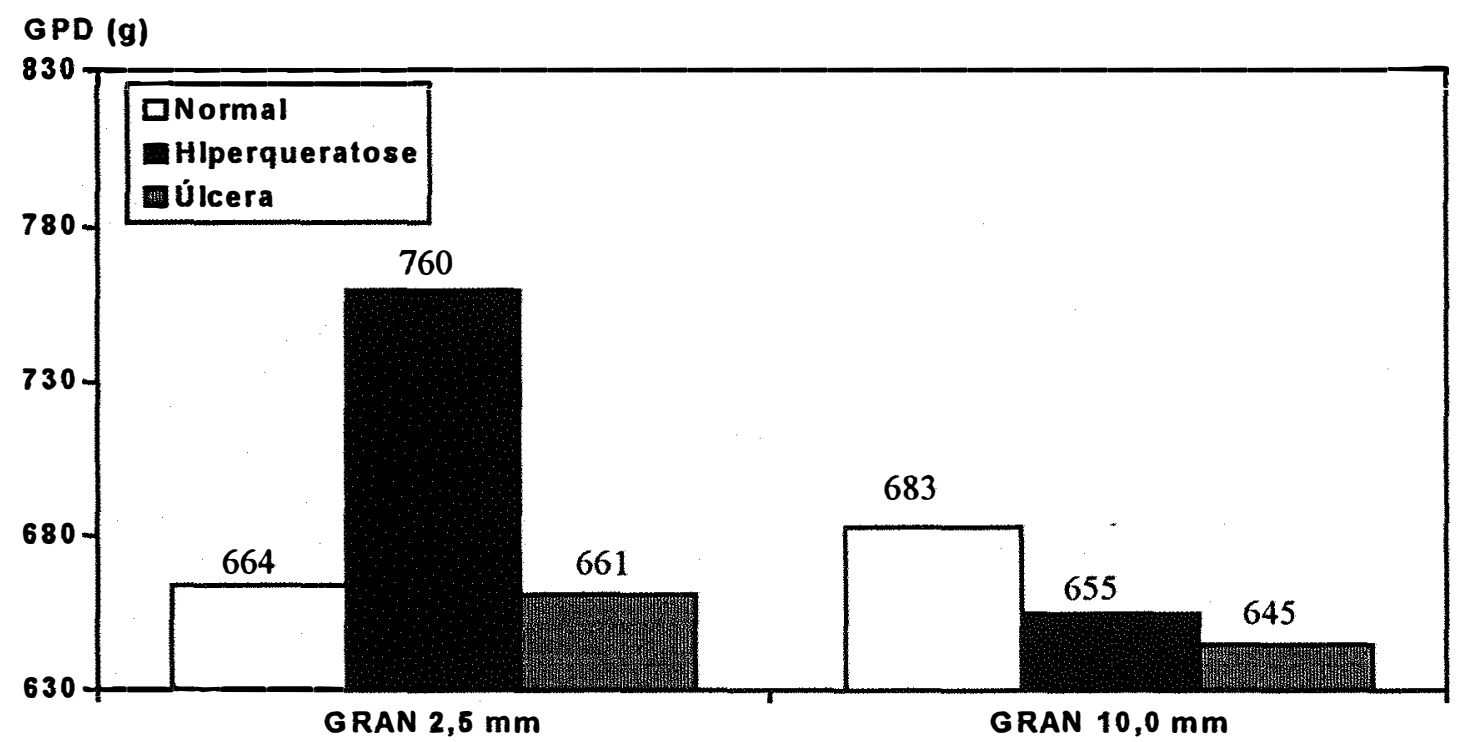

Figura 13 - Efeito granulometria associada a lesões esôfago-gástricas sobre o ganho de peso diário (GPD) na fase crescimento-terminação. 
Tabela 3 - Efeito da área por animal associada a lesões esôfago-gástricas sobre o ganho de peso diário (GPD), em gramas (g), na fase crescimento-terminação.

\begin{tabular}{llll} 
& \multicolumn{3}{c}{ Região esôfago-gástrica } \\
\cline { 2 - 4 } Fator & \multicolumn{1}{c}{ Normal } & Hiperqueratose & \multicolumn{1}{c}{ Úlcera } \\
\cline { 2 - 4 } & \multicolumn{1}{c}{ Média \pm Erro Padrão } & Média \pm Erro Padrão & Média \pm Erro Padrão \\
\hline $0,64 \mathrm{~m}^{2} /$ animal & $679 \pm 21 \mathrm{Aa}$ & $695 \pm 16 \mathrm{Ba}$ & $614 \pm 22 \mathrm{Bb}$ \\
$1,07 \mathrm{~m}^{2} /$ animal & $671 \pm 25 \mathrm{Aa}$ & $758 \pm 20 \mathrm{Aa}$ & $690 \pm 31 \mathrm{ABa}$ \\
$1,64 \mathrm{~m}^{2} /$ animal & $691 \pm 20 \mathrm{Aa}$ & $738 \pm 27 \mathrm{ABa}$ & $731 \pm 61 \mathrm{Aa}$
\end{tabular}

A, $B$ Letras maiúsculas, comparação na coluna.

a,b Letras minúsculas, comparação na linha.

Médias ligadas por letras comuns não diferem pelo teste Tukey $(P<0,05)$.

* Comparações, na coluna, feitas ao nível de $\mathrm{P}<0,1$.

Interação área por animal x lesão $(\mathrm{P}=0,529)$

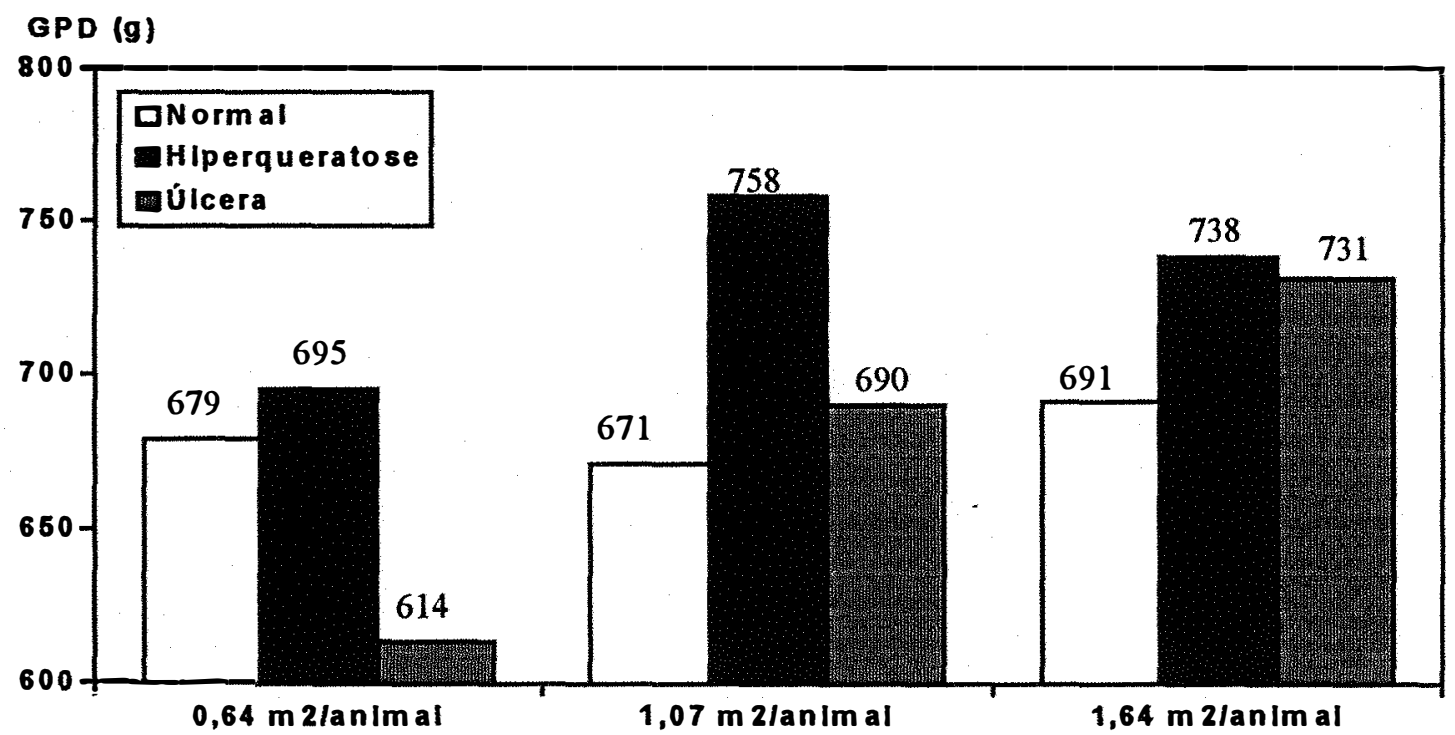

Figura 14 - Efeito da área por animal associada a lesões esôfago-gástricas sobre o ganho de peso diário (GPD) na fase crescimento-terminação. 


\section{CONCLUSÕES}

1. Os suínos em crescimento e terminação aproveitam melhor o milho da dieta quando este é fornecido com diâmetros de partículas menores, sendo que a granulometria mais fina proporcionou maior GPD e CRD e melhor CA.

2. A restrição da área disponível ao animal ou o aumento do tamanho do grupo piora o desempenho de suínos em crescimento e terminação, sendo que quando criados com $0,64 \mathrm{~m}^{2}$ (10 animais/baia) de área disponível por animal tiveram pior desempenho do que suínos submetidos a 1,07 e 1,60 $\mathrm{m}^{2}$.

3. Machos castrados ganham mais peso e consomem mais ração, porém têm pior CA do que fêmeas, nas fases de crescimento e terminação, além do que a diferença de consumo e GPD tendem a aumentar com o tempo.

4. A granulometria do milho da dieta influencia na frequência de hiperqueratose e úlcera na região esôfago-gástrica (Pars esofagea) do estômago de suínos em crescimento e terminação, sendo que maior frequência destas lesões é produzida pelo menor diâmetro das partículas. Contudo, o grau destas alterações é insuficiente para causar prejuizo no desempenho dos animais, bem como, animais com hiperqueratose apresentam maior GPD quando alimentados com granulometria mais fina.

5. Os suínos em crescimento e terminação sofrem efeito detrimental no GPD quando apresentam o PE do estômago ulcerado. 


\section{REFERÊNCIAS BIBLIOGRÁFICAS}

ANDRADE. D.F. de \& SINGER, J. da M. Análise de dados longitudinais. In: SIMPÓSIO NACIONAL DE PROBABILIDADE E ESTATÍSTICA, 7., Campinas, SP. 1986. 1 Anais. Campinas, 1986.

ASSOCIAÇÃO BRASILEIRA DE NORMAS TÉCNICAS. NBR Z217: agregados: determinação da composição granulométrica. Rio de Janeiro, 1987. 5 p.

BARKER, I.K. \& DREUMEL, A.A.van The alimentary system. In: JUBB, K.V.F.; KENNEDY, P.C.; PALMER, N. Pathology of domestic animals. 3. ed. New York, Academic Press, 1985. v. 2, p. 46-47.

BAYLEY, H.S. \& SUMMERS, J.D. Effect of protein level and lysine and methionine supplementation on the performance of growing pigs: responses of different sexes and strains of pigs. Canadian Journal of Animal Science, Ottawa, 48:181-8, 1968.

BERESKIN, B. \& STEELE, N.C. Efficiency of feed utilization in pigs - a review emphazising United States research. Pig News and Information, London, 9(1):11-4, 1988.

BERRUECOS, J.M. \& ROBINSON, O. Inheritance of gastric ulcers un swine. Journal of Animal Science, Champaign, 35:20-3, 1972.

BRUNER, W.H. \& SWIGER, L.A. Effects of sex, season and breed on live and carcass traits at tge ohio swine evalluation station. Journal of Animal Science, Champaign, 27:383-8, 1975. 
BRYANT, M.J. \& EUBANK, R. Effects of stocking rate upon the performance, general activity, and ingestive behaviour of groups of growing pigs. British Veterinary Journal, London, 2:130-9, 1974.

BURRIS, M.J.; ELLIOT, D.O.; NEWMAN, C.W. Effect of protein level and sex on growing-finishing pigs performance. Journal of Animal Science, Champaign, 37:117-20, 1986.

CABRERA, M.R.; HANCOCK, J.D.; HINES, R.H.; BEHNKE, K.C.; BRAMEL-COX, P.J. Sorghum genotype and particle size affect milling characteristics, growth performance, nutrient digestibity, and stomach morphology in finishing pigs. Abstracts American Society of Animal Science. Midwestern Section. March 21-23, p. 55, 1994.

CASTELL, A.G.; CLIPLEF, R.L.; McKAY, R.M. Effects of diet, litter and sex type on the performance (from 22 to $90 \mathrm{kh}$ liveweight) and carcass measurements of crossbred pigs. Pig News and Information, London, 7(2):232, 1986. Resumo.

CIACCI, J.R.; MORES, N.; SOBESTIANSKY, J.; LIEBHOLD, M.M. Úlcera gástrica como causa de morte e como achado de necrópsia em três rebanhos suinos. Arquivo Brasileiro de Medicina Veterinária e Zootecnia, Belo Horizonte, 43(6):525-33, 1991.

CRAMPTON, E.W. \& BELL, J.M. The effect of fineness of grinding on the utilization of oats by market hogs. Journal of Animal Science, Champaign, 5;200-10, 1946.

CHRISTIAN, L.L.; STROCK, K.L.; CARLSON, J.P. Effects of protein, breedcross, sex and slaughter weight on swine performance and carcass traits. Journal of Animal Science, Champaign, 51:51-8, 1980.

CURTIN, T.M.; GOESCH, G.D.; HOLLANDBECK, R. Clinical and pathological characteristics of oesophagogastric ulcers in swine. Journal of American Veterinary Medical Association, Chicago, 143:854-60, 1963.

DOBSON, D.J.; DAVIES, R.L.; CARGILL, C.F. Ulceration of the pars oesophageia in pigs. Australian Veterinary Journal, Victoria, 54:601-2, 1978. 
EDWARDS, S.A.; ARMSBY, A.W.; SPECHT, H.H. Effects of floor area allowance on performance of growing pigs kept on fully slotted floors. Animal Production, Edinburgh, 46(3):453-61, 1988.

EMBRAPA. Centro Nacional de Pesquisa de Suínos e Aves. Tabela de composição química e valores energéticos de alimentos para suínos e aves. 3. ed. Concórdia, 1991. 97 p. (EMBRAPA-CNPSA. Documentos, 19).

EUBANK, R. Social environmental of the pig. In: COLE, D.J.A. Pig production. London, Butterworths, 1972. p. 129-39.

FRITSCHEN, R.D. \& MUEHLING, A.J. Space requirements for swine. West Lafayette, National Pork Producers, 1979. 4 p. (Handbook, PIH-55).

GELBACH, L.; BECKER, D.E.; COX, J.L.; HARMON, B.G.; JENSEN, A.H. Effects of floor space allowance and number per group on performance of growing-finishing swine. Journal of Animal Science, Champaign, 25:386, 1966. Resumo.

HALE, O.M. \& SOUTHWELL, B.L. Differences in swine performance and carcass characteristics because of dietary level, sex and breed. Journal of Animal Science, Champaign, 26:341-44, 1967.

HALE, O.M. \& THOMPSON, L.M. Influence of particle size of wheat on performance of finishing swine. Nutrition Reports International, Los Altos, 33(2):307-11, 1986.

HANDLIN, D.L.; BELLINGTON, D.A.; SKELLEY, G.C.; CROOK, L.; JOHNSTON, W.E. Effect of space restriction and ration on the incidence of stomach ulcers in swine. Journal of Animal Science, Champaign, 35(4):767-71, 1972.

HANKE, H.E. \& MEADE, R.J. Influence of pen shape, or pigs per pen on rate and efficiency of gain in pigs during the final growing period. Minnesota Swine Research Report, p. 3, 1973.

HANSSON, I. Effect of sex and weight on growth, feed eficiency and carcass characteristics of pigs. I. Growth rate and efficiency of boars, barrows and gilts. Swedish Journal of Agricultural Research, Stokholm, 4:209-18, 1974. 
HEDDE, R.D.; LINDSEY, T.O, PARISH, R.C.; DANIELS, H.D. MORGENTHIEN, E.A, LEWIS, H.B. Effect of diet particle size and feeding of H2-receptor antagonists on gastric ulcers in swine Journal of Animal Science, Champaign, 61(1):179-86, 1985.

HEITMAN, D.G. Space allotment and perfornance of growing-finishing swine raised in confinement. Journal of Animal Science, Champaign, 20:543, 1961. Resumo.

HESSING, M.J.C;, GENDEKE, M.J;, SCHEEPENS, C.J.M., TIELEN, M.J.M.; SCHOUTEN, W.G.P, WIEPKEMA, P.R. Mucosal lesions in the pars oesophagea in pigs prevalence os stress. Netherlands Journal of Veterinary Medicine, Ultrecht, 117:445-50, 1992.

HENDERSON, S.M, PERRY, R.L. Agricultural process enginering, New York, J. Willey, 1955.

HSIA, L.C. \& LU, G.H. The effect of slotted floor space and sex on the performance of growing-finishing pigs. World Review on Animal Production, Rome, 21(2):31-4, 1985

HSU, A.; YANG, Y.F.; LIAO, C.W. Effect of particle size of corn and physical form of diet on performance in growing-finishing pigs. Journal of Chinese Society Veterinary Science, 14(3-4):47-54, 1985.

IVAN, M.; GILLES, L.R.; ALIMON, A.R; FARRELL, D.J. Nutritional evaluation of wheat. I. Effects of preparation on digestibility of dry matter, energy and nitrogen in pigs. Animal Production, Edinburgh, 19:359-65, 1974.

JENSEN, A.H. Concepts and trends in modern swine housing facilities and waste disposal. In: BIENNIAL SWINE PRODUCERS SHORT COURSE, 5., Ithaca, NY, 1973. Proceedings. Ithaca, Cornell University, 1973.

KIRCHGESSNER, V.M.; ROTH, F.X.; BOLLWAHN, W.; HEINRITZI, K. Mastleistung, Nahrstoffverdaulichkeit und Magenschleimhautveranderungen von schweinen bei unterschiedlicher Futterstruktur. I Einflub eines unterschiedlicher Vermahlungegrades des Futters. Zentralblatt fuer Veterinarmedizin A, Berlin, 32(9):641-51, 1985. 
KRIDER, J.L; ALBRIGHT, J.L.; PLUMLEE, M.P.; CONRAD, J.H.; SINCLAIR, C.L.; UNDERWOOD, L.; JONES, R.G.; HARRINGTON, R.B. Magnesium supplementation, space and docking effects on swine performance and behaviour. Journal of Animal Science, Champaign, 40:1027-33, 1975.

KORNEGAY, E.E. \& NOTTER, D.R. Effects of floor space and number of pigs per pen on performance. Pigs News and Information. London, 5:23-3, 1984.

KUAN, K.K. \& MARK, T.K. Performance of gilts and castrates when fed separately on two differents levels of feeding. Pigs News and Information. London, 4(2):218, 1983. Resumo.

LAWRENCE, T.L.J. A review of some effects on health and performance of variation in the physical form of the diet of the growing pig. I. Cereal processing. Veterinary Record, London, 91:67-70, 1972.

LIMA, G.J.M.M. de; GOMES, P.C.; BARIONI J̈UNIOR, W.; CRIPPA, J; ZANOTTO, D.L. Influência do grau de moagem do farelo de girassol com casca sobre a digestibilidade da proteína brute e energia. In: SOCIEDADE BRASILEIRA DE ZOOTECNIA, 27., 1990, Campinas, Brasil. Anais... , Campinas, Brasil, 1990. p. 198.

LIN, J.H.; WU, J.F.; WENG, C.F. The effect of particle size of diets on the incidence of gastric ulcers of growing-finishing pigs. Journal of Chinese Society Veterinary Science, 14:153-58, 1988.

LIPTRAP, D.O. \& HOGBER, M.G. Physical forms od feed: feed processing and feeder design and operation. In: MILLER, E.R.; ULREY, D.E.; LEWIS,A.J Swine Nutrition. Butterworth-Heinemann, 1991. p. 373-86.

MADSEN, A. \& NIELSEN, E.T. Housing systems and muscle developmente and quality in pigs. Acta Veterinaria Scandinavica, Copenhagen, 5:265-72, 1979. Suplemento. 
MAHAN, D.C.; PICKETT, R.A.; PERRY, T.W.; CURTIN, T.M.; FEATHERSTON, W.R.; BEESOW, W.M. Influence of various nutritional factors and physical form of feed on oesophagogastric ulcers in swine. Journal of Animal Science, Champaign, 25(4): 1019-23, 1966.

MAHAN, D.C. \& GERBER, D.B. Gilt and barrow performance measurements from 60 to $135 \mathrm{~kg}$ bodyweight. Nutrition Reports International, Los Altos, 31(5):1015-22, 1985.

MARQUES, J.L.L.; MORES, N.; SOBESTIANSKY, J.; CIACCI, J.R. Causas de morte súbita em suínos. III Úlcera gástrica. Concórdia, EMBRAPA-CNPSA, 1989. 4 p. (EMBRAPA-CNPSA, Comunicado Técnico, 142).

MAXWELL, C.Y. Jr.; REIMANN, E.M.; HOEKSTRA, W.G; KOWALCZYK, T.; BENEVENGA, N.J.; GRUMMER, R.H. Effect of dietary particle size on lesion development and on the contents of various regions of the swine stomach. Journal of Animal Science, Champaign, 30(6):911-22, 1970.

MEUNIER-SALAUN, M.C.; VANTRIMPONTE, M.N.; RAAB, A.; DANTZER, R. Effect of floor area restriction upon performance, behaviour and physiology of growingfinishing pigs. Journal of Animal Science, Champaign, 64:1371-7, 1987.

MILLER, K.P. The effect of number of pigs per pen and pen size on rate and efficiency of gain of growing-finishing pigs. Minnesota Swine Research Report, p. 3-4, 1976.

MORAN Jr, E.T. Comparative nutrition of fowl and swine: the gastrointestinal systems. Guelph, University of Guelph, 1982. 1 v.

MOREIRA, I. Efeito da densidade populacional sobre o desempenho de suínos em crescimento e terminação. Viçosa, MG, 1981, 80 p. (Mestrado-Universidade Federal de Viçosa).

MUGGENBURG, B.A.; REESE, N.; KOWALCZYK, T.; GRUMMER, R.H.; HOEKSTRA, W.G. Survery of the prevalence of gastric ulcers in swine. American Journal of Veterinary Research, Schaumburg, 25:1673-78, 1964. 
MUGGENBURG, B.A.; REIMANN, E.M.; KOWALCZYK, T.; HOEKSTRA, W.G. Effect of reserpine and histamine in mineral oil-beeswax vehicle on gastric secretions in swine. American Journal of Veterinary Research, Schaumburg, 28:1427-35, 1967.

NATIONAL RESEARCH COUNCIL. Committe on Animal Nutrition. Subcommitte on Swine Nutrition (Washington, EUA). Nutrient requirements of swine. 8. ed. Washington, National Academy Press, 1988.93 p.

NUWER, T.W. Expanded or heat-processed fractions of corn and their relative ability to elicit esophagogastric ulcers in swine. Journal of Animal Science, Champaign, 26(1-3):518-25, 1967.

O'BRIEN, J.J Gastric ulcers. In: LEMAN, A.D.; STRAW, B.; GLOCK, R.D.; MENGELING, W.; PENNY, R.H.C.; SCHOLL, E. eds. Diseases of swine. 7. ed. Ames, Iowa State University Press, 1992. p. 681-691.

OHH, S.J.; ALLEE, G.; BEHNKE, K.C.; DEYDE, C.W. Effects of particle size of corn and sorghum grain on performance and digestibility of nutrients for weaned pigs. In: AAAp ANIMAL SCIENCES CONGRESS, 3., 1985, Seoul, Korea. Proceedings... Seoul, Korea Republic, The Organizing Committe, 1985. v. 2, p. 582-5,

PETHERICK, C. \& BAXTER, S. Space requirements for pigs. Pig Farming. Suffolk, 30:88-93, 1982.

PICKETT, R.A.; FUGADE, W.H.; HARRINGTON, R.B.; PERRY, T.W.; CURTIN, T.M. Influence of the feed preparation and number of pigs per pen on performance and occurrence of oesophagogastric ulcers in swine. Journal of Animal Science, Champaign, 28(6):837-41, 1969.

POND, W.G. \& MANER, J.H. Producción de cerdos en climas templados y tropicales. Zaragoza, Acribia, 1974. 875 p.

POTKINS, Z.Y \& LAWRENCE, T.L.J. Oesophagogastric parakeratosis in the growing pig: effects of the physical form of barley-based diets and added fiber. Research in Veterinary Science, Oxford, 47(1):60-7, 1989. 
RANDOLPH, J.H; CROMWELL, G.L.; STAHLY, T.S.; KRATZER, D.D. Effects of group size and space allowance on performance and behaviour of swine. Journal of Animal Science, Champaign, 53:922-7, 1981.

REIMANN, E.M.; MAXWELL, C.V. Jr.; KOWALCZYK, T.; BENEVENGA, N.J.; GRUMMER, R.H.; HOEKSTRA, W.G. Effect of fininess of grind of corn on gastric lesions and contents of swine. Journal of Animal Science, Champaign, 27:992-9, 1968.

RIKER III, J.T.; PERRY, T.W.; PICKETT, R.A.; CURTIN, T.M. Influence of various grains on the incidence of oesophagogastric ulcers in swine. Journal of Animal Science, Champaign, 26:731-5, 1967a.

RIKER III, J.T; PERRY, T.W.; PICKETT, R.A.; HEIDENREICH, C.J.; CURTIN, T.M. Influence of controled ambiente temperatures and diets on the incidence of oesophagogastric ulcers in swine. Journal of Animal Science, Champaign, 26(4-6): 736-40, $1967 \mathrm{~b}$.

SAS INSTITUTE INC. SAS user's guide: statistics. 5 ed. Cary, 1985. 956 p.

SCHIRVEL, C. \& HANSET, R. Effects of season, sex, initial age, and initial and final weights on fattening performance and carcass composition of Pietrain pigs tested at the Wavre Selection Stations (Belgium) between 1982 and 1986. Annales de Médecine Vétérinaire, Bruxeles, 132:307-30, 1988.

SEERLEY, R.W.; VANDERGRIFT, W.L.; HALE, O.M. Effect of particle size of wheat on performance of nursery, growing and finishing pigs. Journal of Animal Science, Champaign, 66:2484-9, 1988.

SENK, L. Incidence, morphology, morphogenesis and complications of gastric ulcer in postmortem examined pigs in Slovenia during 1963-1983. In: INTERNATIONAL PIG VETERINARY SOCIETY, 1986, Barcelona. Proceedings, IPVS, 3:378. 1986.

SIERS, D.G. Live and carcass traits in individually fed Yorkshire boars, barrows and gilts. Journal of Animal Science, Champaign, 41:522-6, 1975. 
STRAW, B.; HENRY, S.; NELSSEN, J.; DOSTER, A. MOXLEY, R. ROGERS, D.; WEBB, D. Prevalence of gastric ulcers in normal, sick and feed-deprived pigs. Abstracts American Society of Animal Science. Midwestern Section. March 21-23, p. 51, 1994.

TAMÁS, J.; BOKORI, J.; HEGEDUS, M. Oesophagogastic ulcer in swine and vitamin U. I. Relative incidence of the sindrome in Hungary. Acta Veterinaria Hungarica, Hungary, 31(4): 145-53, 1983.

TANNOCK, G.W.; SMITH, J.M.B. The microflora of the pigs stomach and its possible relationship to ulceration of the "Pars Oesophagea". Journal of Comparative Pathology, London, 8:359, 1970. Resumo.

THOMAS, K. \& SINGH, R.A. Feeding pigs in tropics: I. Effect of plan of feeding and feed article size on growth. Kerala Journal of Veterinary Science, Kerela, 5(2):51-60, 1984.

TRIVELIN, A.P.; LAVORENTI, A.; ROSS, J.R. da. Formas de fornecimento de milho na alimentação de leitões em crescimento. O Solo, Piracicaba, 61(1):33-9, 1969.

WALKER, N. The interactions of stocking density, form of diet and sex group of finishing pigs fed ad libitum. Irish Journal of Agricultural Research, Eire, 28(2):109-13, 1989.

WALKER, R.D.; SHURSON, G.C.; PETTIGREW, J.E. An evaluation of choice feeding in grow-finish pigs separated by sex. Abstracts American Society of Animal Science. Midwestern Section. March 21-23, p. 61, 1994.

WATKINS, L.E.; SWIGER, L.A. MAHAN, D.C. Effects and interactions of breed group, sex and protein level on performance of swine. Journal of Animal Science, Champaign, 45:24, 1977. Resumo.

WONDRA, K.J.; HANCOCK, J.D.; KENNEDY, G.A.; BEHNKE, K.C.; WONDRA, K.R. Reducing particle size of corn improves energy and nitrogen utilization in second-parity sows. Abstracts American Society of Animal Science. Midwestern Section. March 21-23, p. 65, 1994. 
WU, J.F.; WENG, C.F.; YEN, H.T. Effect of particle size and surface area of corn diets on the performance of growing-finishing pigs Journal of Agricultural Association Chinese, 134:71-8, 1986.

WU, J.F.; CHENG, C.S.; YU, I.T. The effect of particle size and surface area of dry rolling of sorghum grain on the griding efficiency and performance of growing-finishing pigs. Journal of Agricultural Association Chinese, 138:87-95, 1987.

WU, J.F.; LIN, J.H.; CHENG, C.S. Hammermill versus roller mill processing for pigs. II. The effects of particle size of different methods of corn diets on apparent digestibilities, the rate of passage, and the incidence os gastric ulcers for growing-finishing pigs. Journal of Agricultural Association Chinese, 146;59-68, 1989.

YANG, Y.F.; LIAO, C.W.; HSU, A. Effect of particle size of corn and diameter of pellet on feed production efficiency, performance and nutrient digetibilities of growing-finishing pigs. Journal of Chinese Society of Animal Science, 17(1-2):17-28, 1988.

ZANOTTO, D.L. Granulometria do milho em rações para suinos em crescimento e terminação. digestibilidade, desempenho e alterações gástricas. Porto Alegre, RS, 1992. 106 p. (Mestrado-Faculdade de Agronomia/UFGRS). 
A P E NDICE 
Tabela 4 - Análise de variância longitudinal do ganho de peso diário (GPD) envolvendo a fase de crescimento ( 1 a 45 dias).

\begin{tabular}{|c|c|c|c|c|}
\hline Fontes de variação & GL, & Soma de Quadrados & Teste F & $\mathrm{P}>\mathrm{F}$ \\
\hline Bloco & 3 & 184068,28 & - & - \\
\hline Granulometria (Gran) & 1 & 169545,69 & 13,50 & 0,0008 \\
\hline Área por animal (Área) & 2 & 131710,35 & 5,24 & 0,0105 \\
\hline Sexo & 1 & 36403,23 & 2,90 & 0,0981 \\
\hline Gran x Área & 2 & 26310,82 & 1,05 & 0,3623 \\
\hline Gran x Sexo & 1 & 8,89 & 0,00 & 0,9789 \\
\hline Área x Sexo & 2 & 40605,65 & 1,62 & 0,2140 \\
\hline Gran x Área x Sexo & 2 & 5968,64 & 0,24 & 0,7899 \\
\hline Erro (a) & 33 & 414566,71 & - & - \\
\hline Período de avaliação (Peava) & 2 & 466704,00 & 42,03 & 0,0001 \\
\hline Gran $x$ Peava & 2 & 11607,18 & 1,05 & 0,3568 \\
\hline Área x Peava & 4 & 1087,14 & 0,05 & 0,9954 \\
\hline Sexo $\times$ Peava & 2 & 4922,13 & 0,44 & 0,6436 \\
\hline Gran x Área x Peava & 4 & 7853,30 & 0,35 & 0,8407 \\
\hline Gran x Sexo x Peava & 2 & 19746,82 & 1,78 & 0,1762 \\
\hline Área x Sexo x Peava & 4 & 36149.17 & 1,63 & 0,1766 \\
\hline Gran x Área x Sexo x Peava & 4 & 3354,76 & 0,15 & 0,9619 \\
\hline Erro (b) & 72 & 399713,29 & & \\
\hline $\begin{array}{l}\text { Total } \\
\mathrm{R}^{2}(\%)=79,61\end{array}$ & $\begin{aligned} & 143 \\
= & 11,60\end{aligned}$ & $\begin{array}{r}1960326,04 \\
\mathrm{GPD}(\mathrm{g})=642\end{array}$ & & \\
\hline
\end{tabular}

Tabela 5 - Análise de variância longitudinal do consumo de ração diário (CRD) envolvendo a fase de crescimento ( 1 a 45 dias).

\begin{tabular}{|c|c|c|c|c|}
\hline Fontes de variação & $\mathrm{GL}$ & Soma de Quadrados & Teste F & $\mathrm{P}>\mathrm{F}$ \\
\hline Bloco & 3 & 1249217,76 & - & - \\
\hline Granulometria (Gran) & 1 & 471078,86 & 7,43 & 0,0102 \\
\hline Área por animal (Área) & 2 & 498537,19 & 3,93 & 0,0294 \\
\hline Sexo & 1 & 361935,93 & 5,71 & 0,0228 \\
\hline Gran x Área & 2 & 133036,37 & 1,05 & 0,3618 \\
\hline Gran $x$ Sexo & 1 & 9412,59 & 0,15 & 0,7025 \\
\hline Área x Sexo & 2 & 109735,56 & 0,87 & 0,4303 \\
\hline Gran $x$ Área $x$ Sexo & 2 & 100914,57 & 0,80 & 0,4598 \\
\hline Erro (a) & 33 & 2093010,55 & - & - \\
\hline Pcriodo dc avaliação (Pcava) & 2 & 7551097,51 & 245,20 & 0,0001 \\
\hline Gran $\times$ Peava & 2 & 114501,29 & 3,72 & 0,0291 \\
\hline Área x Peava & 4 & 10712,53 & 0,17 & 0,9511 \\
\hline Sexo $\times$ Peava & 2 & 63326,43 & 2,06 & 0,1354 \\
\hline Gran $x$ Área $x$ Peava & 4 & 61623,10 & 1,00 & 0,4131 \\
\hline Gran $x$ Sexo $x$ Peava & 2 & 14783,18 & 0,48 & 0,6207 \\
\hline Área x Sexo x Peava & 4 & 119505,91 & 1,94 & 0,1130 \\
\hline Gran $x$ Área $x$ Sexo $x$ Pcava & 4 & 37749,11 & 0,61 & 0,6547 \\
\hline Erro (b) & 72 & 1108646,79 & & \\
\hline Total & 143 & 14108825,23 & & \\
\hline
\end{tabular}


Tabela 6 - Análise de variância longitudinal da conversão alimentar (CA) envolvendo a fase de crescimento ( 1 a 45 dias).

\begin{tabular}{|c|c|c|c|c|}
\hline Fontes de variação & GL & Soma de Quadrados & Teste F & $\mathrm{P}>\mathrm{F}$ \\
\hline Bloco & 3 & 0,136 & - & - \\
\hline Granulometria (Gran) & 1 & 0,766 & 13,83 & 0,0007 \\
\hline Árca por animal (Área) & 2 & 0,286 & 2,58 & 0,0908 \\
\hline Sexo & 1 & 0,040 & 0,72 & 0,4023 \\
\hline Gran x Área & 2 & 0,115 & 1,04 & 0,3651 \\
\hline Gran $x$ Sexo & 1 & 0,038 & 0,68 & 0,4148 \\
\hline Área x Scxo & 2 & 0,221 & 2,00 & 0,1515 \\
\hline Gran x Área x Sexo & 2 & 0,017 & 0,15 & 0,8617 \\
\hline Erro (a) & 33 & 1,829 & - & - \\
\hline Período de avaliação (Peava) & 2 & 7,248 & 42,01 & 0,0001 \\
\hline Gran x Pcava & 2 & 0,088 & 0,51 & 0,6024 \\
\hline Árca x Peava & 4 & 0,223 & 0,65 & 0,6309 \\
\hline Scxo $\times$ Peava & 2 & 0,027 & 0,16 & 0,8536 \\
\hline Gran x Árca x Pcava & 4 & 0,218 & 0,63 & 0,6665 \\
\hline Gran x Sexo x Peava & 2 & 0,152 & 0,88 & 0,4177 \\
\hline Área $\times$ Sexo x Peava & 4 & 0,245 & 0,71 & 0,5869 \\
\hline Gran x Árca x Scxo x Pcava & 4 & 0,097 & 0,28 & 0,8888 \\
\hline Erro (b) & 72 & 6,211 & & \\
\hline $\begin{array}{l}\text { Total } \\
\mathrm{R}^{2}(\%)=65,41\end{array}$ & $\begin{array}{l}143 \\
0,33\end{array}$ & $\begin{array}{r}17,99 \\
2,842\end{array}$ & & \\
\hline
\end{tabular}

Tabela 7 - Análise de variância longitudinal do ganho de peso diário (GPD) envolvendo a fase crescimento-terminação ( 1 a 87 dias)

\begin{tabular}{|c|c|c|c|c|}
\hline Fontes de variação & GL & Soma de Quadrados & Teste F & $\mathrm{P}>\mathrm{F}$ \\
\hline Bloco & 3 & 596465,39 & - & - \\
\hline Granulometria (Gran) & 1 & 267583,38 & 10,78 & 0,0024 \\
\hline Área por animal (Área) & 2 & 217123,12 & 4,37 & 0,0206 \\
\hline Sexo & 1 & 125016,20 & 5,04 & 0,0316 \\
\hline Gran x Árca & 2 & 46558,48 & 0,94 & 0,4016 \\
\hline Gran $x$ Sexo & 1 & 1906,00 & 0,08 & 0,7834 \\
\hline Árca x Sexo & 2 & 54114,42 & 1,09 & 0,3479 \\
\hline Gran x Área x Sexo & 2 & 13332,42 & 0,27 & 0,7661 \\
\hline Erro (a) & 33 & 818966,07 & - & - \\
\hline Período de avaliação (Peava) & 5 & 1617108,84 & 47,88 & 0,0001 \\
\hline Gran $\times$ Peava & 5 & 22884,90 & 0,68 & 0,6410 \\
\hline Área $x$ Peava & 10 & 11779,28 & 0,17 & 0,9978 \\
\hline Sexo $x$ Peava & 5 & 14436,35 & 0,43 & 0,8292 \\
\hline Gran $\times$ Área $\times$ Peava & 10 & 43659,87 & 0,65 & 0,7726 \\
\hline Gran x Scxo x Pcava & 5 & 40000,67 & 1,18 & 0,3186 \\
\hline Área x Sexo x Peava & 10 & 43120,96 & 0,64 & 0,7796 \\
\hline Gran $\times$ Área $\times$ Sexo $\times$ Peava & 10 & 27698,48 & 0,41 & 0,9406 \\
\hline Erro (b) & 180 & 1215950,92 & & \\
\hline Total & 287 & 5177705,74 & & \\
\hline$R^{2}(\%)=76,52$ & 1,70 & $(g)=702$ & & \\
\hline
\end{tabular}


Tabela 8 - Análise de variância longitudinal do consumo de ração diário (CRD) envolvendo a fase crescimento-terminação ( 1 a 87 dias).

\begin{tabular}{|c|c|c|c|c|}
\hline Fontes de variação & GL & Soma de Quadrados & Teste F & $\mathrm{P}>\mathrm{F}$ \\
\hline Bloco & 3 & 4348327,31 & - & - \\
\hline Granulometria (Gran) & 1 & 722894,97 & 4,10 & 0,0511 \\
\hline Área por animal (Área) & 2 & 1362886,66 & 3,86 & 0,0311 \\
\hline Sexo & 1 & 2166772,69 & 12,28 & 0,0013 \\
\hline Gran x Área & 2 & 367069,12 & 1,04 & 0,3646 \\
\hline Gran $x$ Sexo & 1 & 2732,13 & 0,02 & 0,9017 \\
\hline Área x Sexo & 2 & 183482,50 & 0,52 & 0,5993 \\
\hline Gran $x$ Área x Sexo & 2 & 134757,09 & 0,38 & 0,6855 \\
\hline Erro (a) & 33 & 5821497,37 & - & 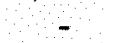 \\
\hline Período de avaliação (Pcava) & 5 & 54616517,57 & 509,28 & 0,0001 \\
\hline Gran $\times$ Peava & 5 & 265442,61 & 2,48 & 0,0339 \\
\hline Área x Peava & 10 & 121091,74 & 0,56 & 0,8413 \\
\hline Sexo $\times$ Peava & 5 & 471975,97 & 4,40 & 0,0008 \\
\hline Gran x Área x Pcava & 10 & 181956,32 & 0,85 & 0,5828 \\
\hline Gran $\times$ Sexo $\times$ Pcava & 5 & 92497,02 & 0,86 & 0,5075 \\
\hline Área $\times$ Sexo $\times$ Peava & 10 & 324925,80 & 1,51 & 0,1371 \\
\hline Gran $\times$ Área $\times$ Sexo $\times$ Peava & 10 & 157088,99 & 0,73 & 0,6933 \\
\hline Erro (b) & 180 & 3860717,93 & & \\
\hline Total & 287 & 75202633,80 & & \\
\hline
\end{tabular}

Tabela 9 - Análise de variância longitudinal da conversão alimentar (CA) envolvendo a fase crescimento-terminação (1 a 87 dias).

\begin{tabular}{|c|c|c|c|c|}
\hline Fontes de variação & GL & Soma de Quadrados & Teste F & $\mathrm{P}>\mathrm{F}$ \\
\hline Bloco & 3 & 0,884 & - & \\
\hline Granulometria (Gran) & 1 & 1,466 & 21,22 & 0,0001 \\
\hline Área por animal (Área) & 2 & 0,264 & 1,91 & 0,1644 \\
\hline Sexo & 1 & 0,321 & 4,65 & 0,0385 \\
\hline Gran x Área & 2 & 0,084 & 0,61 & 0,5508 \\
\hline Gran $x$ Sexo & 1 & 0,013 & 0,18 & 0,6724 \\
\hline Área $x$ Sexo & 2 & 0,322 & 2,33 & 0,1129 \\
\hline Gran $x$ Área $x$ Sexo & 2 & 0,005 & 0,04 & 0,9624 \\
\hline Erro (a) & 33 & 2,280 & - & - \\
\hline Período de avaliação (Peava) & 5 & 33,624 & 75,33 & 0,0001 \\
\hline Gran $x$ Peava & 5 & 0,185 & 0,42 & 0,8378 \\
\hline Área $x$ Peava & 10 & 0,312 & 0,35 & 0,9657 \\
\hline Sexo $\times$ Peava & 5 & 0,231 & 0,52 & 0,7622 \\
\hline Gran $x$ Área $x$ Peava & 10 & 0,640 & 0,72 & 0,7082 \\
\hline Gran $x$ Sexo $x$ Peava & 5 & 0,328 & 0,73 & 0,5989 \\
\hline Área $x$ Sexo $x$ Peava & 10 & 0,474 & 0,53 & 0,8671 \\
\hline Gran $x$ Área $x$ Sexo $x$ Peava & 10 & 0,208 & 0,23 & 0,9926 \\
\hline Erro (b) & 180 & 16,070 & & \\
\hline Total & 287 & 57,712 & & \\
\hline
\end{tabular}


Tabela 10 - Médias longitudinais e resumo para ganho de peso diário (GPD), consumo de ração diário (CRD) e conversão alimentar (CA), por animal em cada período de avaliação, envolvendo a fase de crescimento-terminação ( 1 a 87 dias), referente às diferentes combinações (granulometria $\mathrm{x}$ Área $\mathrm{x}$ sexo).

\begin{tabular}{|c|c|c|c|c|c|c|}
\hline Granulometria & Area & SEXO & $\begin{array}{l}\text { Períodos de } \\
\text { Avaliação } \\
\text { (dias) }\end{array}$ & média $\pm E P$ & médiatEP & média $\pm E P$ \\
\hline 1 & 1 & 1 & $1-15$ & $572 \pm 6$ & $1455 \pm 11$ & $2,543 \pm 0,021$ \\
\hline 1 & 1 & 1 & $16-30$ & $571 \pm 35$ & $1687 \pm 48$ & $2,976 \pm 0,111$ \\
\hline 1 & 1 & 1 & $31-45$ & $722 \pm 21$ & $2047 \pm 51$ & $2,838 \pm 0,025$ \\
\hline 1 & 1 & 1 & $46-59$ & $681 \pm 20$ & $2313 \pm \quad 44$ & $3,408 \pm 0,131$ \\
\hline 1 & 1 & 1 & $60-73$ & $730 \pm 25$ & $2463 \pm 62$ & $3,378 \pm 0,090$ \\
\hline 1 & 1 & 1 & $74-87$ & $786 \pm 55$ & $2493 \pm 111$ & $3,193 \pm 0,106$ \\
\hline 1 & 1 & 2 & $1-15$ & $610 \pm 76$ & $1506 \pm 138$ & $2,513 \pm 0,126$ \\
\hline 1 & 1 & 2 & $16-30$ & $554 \pm 75$ & $1729 \pm 123$ & $3,204 \pm 0,217$ \\
\hline 1 & 1 & 2 & $31-45$ & $668 \pm 49$ & $2040 \pm 134$ & $3,058 \pm 0,028$ \\
\hline 1 & 1 & 2 & $46-59$ & $692 \pm 83$ & $2371 \pm 187$ & $3,483 \pm 0,184$ \\
\hline 1 & 1 & 2 & $60-73$ & $766 \pm 62$ & $2606 \pm 181$ & $3,412 \pm 0,053$ \\
\hline 1 & 1 & 2 & $74-87$ & $774 \pm 61$ & $2593 \pm 237$ & $3,351 \pm 0,200$ \\
\hline 1 & 2 & 1 & $1-15$ & $605 \pm 28$ & $1505 \pm 59$ & $2,490 \pm 0,045$ \\
\hline 1 & 2 & 1 & $16-30$ & $624 \pm 32$ & $1781 \pm 71$ & $2,862 \pm 0,070$ \\
\hline 1 & 2 & 1 & $31-45$ & $753 \pm 41$ & $2066 \pm 95$ & $2,751 \pm 0,049$ \\
\hline 1 & 2 & 1 & $46-59$ & $767 \pm 55$ & $2431 \pm 67$ & $3,199 \pm 0,151$ \\
\hline 1 & 2 & 1 & $60-73$ & $783 \pm 44$ & $2666 \pm 58$ & $3,430 \pm 0,154$ \\
\hline 1 & 2 & 1 & $74-87$ & $795 \pm 43$ & $2635 \pm 134$ & $3,323 \pm 0,104$ \\
\hline 1 & 2 & 2 & $1-15$ & $720 \pm 37$ & $1707 \pm 90$ & $2,371 \pm 0,028$ \\
\hline 1 & 2 & 2 & $16-30$ & $719 \pm 34$ & $2027 \pm 92$ & $2,822 \pm 0,088$ \\
\hline 1 & 2 & 2 & $31-45$ & $828 \pm 52$ & $2398 \pm 149$ & $2,902 \pm 0,083$ \\
\hline 1 & 2 & 2 & $46-59$ & $868 \pm 68$ & $2831 \pm 121$ & $3,292 \pm 0,135$ \\
\hline 1 & 2 & 2 & $60-73$ & $841 \pm 12$ & $2817 \pm 182$ & $3,358 \pm 0,254$ \\
\hline 1 & 2 & 2 & $74-87$ & $907 \pm 26$ & $2982 \pm 93$ & $3,288 \pm 0,019$ \\
\hline 1 & 3 & 1 & $1-15$ & $654 \pm 24$ & $1593 \pm 45$ & $2,439 \pm 0,064$ \\
\hline 1 & 3 & 1 & $16-30$ & $667 \pm 32$ & $1916 \pm 35$ & $2,900 \pm 0,186$ \\
\hline 1 & 3 & 1 & $31-45$ & $780 \pm 17$ & $2208 \pm 27$ & $2,830 \pm 0,030$ \\
\hline 1 & 3 & 1 & $46-59$ & $754 \pm 70$ & $2538 \pm 111$ & $3,408 \pm 0,151$ \\
\hline 1 & 3 & 1 & $60-73$ & $798 \pm 38$ & $2669 \pm 100$ & $3,352 \pm 0,060$ \\
\hline 1 & 3 & 1 & $74-87$ & $824 \pm 103$ & $2635 \pm 211$ & $3,273 \pm 0,241$ \\
\hline 1 & 3 & 2 & $1-15$ & $651 \pm 86$ & $1621 \pm 140$ & $2,534 \pm 0,125$ \\
\hline 1 & 3 & 2 & $16-30$ & $661 \pm 18$ & $1953 \pm 68$ & $2,961 \pm 0,146$ \\
\hline 1 & 3 & 2 & $31-45$ & $817 \pm 75$ & $2325 \pm 191$ & $2,855 \pm 0,038$ \\
\hline 1 & 3 & 2 & $46-59$ & $833 \pm 86$ & $2830 \pm 170$ & $3,451 \pm 0,217$ \\
\hline 1 & 3 & 2 & $60-73$ & $794 \pm 22$ & $2922 \pm 93$ & $3,689 \pm 0,145$ \\
\hline 1 & 3 & 2 & $74-87$ & $818 \pm 16$ & $2854 \pm 87$ & $3,488 \pm 0,080$ \\
\hline 2 & 1 & 1 & $1-15$ & $540 \pm 25$ & $1335 \pm 91$ & $2,477 \pm 0,152$ \\
\hline 2 & 1 & 1 & $16-30$ & $529 \pm 25$ & $1628 \pm 38$ & $3,096 \pm 0,150$ \\
\hline 2 & 1 & 1 & $31-45$ & $653 \pm 30$ & $1971 \pm 71$ & $3,024 \pm 0,040$ \\
\hline 2 & 1 & 1 & $46-59$ & $686 \pm 56$ & $2310 \pm 89$ & $3,402 \pm 0,142$ \\
\hline 2 & 1 & 1 & $60-73$ & $706 \pm 44$ & $2502 \pm 91$ & $3,567 \pm 0,137$ \\
\hline 2 & 1 & 1 & $74-87$ & $710 \pm 42$ & $2474 \pm 54$ & $3,522 \pm 0,213$ \\
\hline
\end{tabular}


Tabela 10 - Médias longitudinais e resumo para ganho de peso diário (GPD), consumo de ração diário (CRD) e conversão alimentar (CA), por animal em cada período de avaliação, envolvendo a fase de crescimento-terminação ( 1 a 87 dias), referente às diferentes combinações (granulometria x Área x sexo).

\begin{tabular}{|c|c|c|c|c|c|c|}
\hline Granulometria & Área & SEXO & $\begin{array}{l}\text { Períodos de } \\
\text { Avaliação } \\
\text { (dias) }\end{array}$ & $\mathrm{GPD}(\mathrm{g})$ & CRD (g) & média $\pm E P$ \\
\hline 2 & 1 & 2 & $1-15$ & $576 \pm 38$ & $1544 \pm 91$ & $2,687 \pm 0,050$ \\
\hline 2 & 1 & 2 & $16-30$ & $541 \pm 28$ & $1703 \pm 24$ & $3,168 \pm 0,137$ \\
\hline 2 & 1 & 2 & $17-45$ & $665 \pm 36$ & $2050 \pm 75$ & $3,093 \pm 0,068$ \\
\hline 2 & 1 & 2 & $46-59$ & $687 \pm 49$ & $2416 \pm 71$ & $3,553 \pm 0,179$ \\
\hline 2 & 1 & 2 & $60-73$ & $734 \pm 58$ & $2636 \pm 149$ & $3,615 \pm 0,133$ \\
\hline 2 & 1 & 2 & $74-87$ & $776 \pm 93$ & $2744 \pm 216$ & $3,617 \pm 0,253$ \\
\hline 2 & 2 & 1 & $1-15$ & $598 \pm 36$ & $1636 \pm 100$ & $2,736 \pm 0,029$ \\
\hline 2 & 2 & 1 & $16-30$ & $542 \pm 38$ & $1657 \pm 77$ & $3,082 \pm 0,134$ \\
\hline 2 & 2 & 1 & $17-45$ & $660 \pm 33$ & $1958 \pm 101$ & $2,967 \pm 0,023$ \\
\hline 2 & 2 & 1 & $46-59$ & $660 \pm 71$ & $2235 \pm 153$ & $3,426 \pm 0,137$ \\
\hline 2 & 2 & 1 & $60-73$ & $663 \pm 42$ & $2443 \pm 159$ & $3,689 \pm 0,091$ \\
\hline 2 & 2 & 1 & $74-87$ & $759 \pm 62$ & $2591 \pm 150$ & $3,445 \pm 0,155$ \\
\hline 2 & 2 & 2 & $1-15$ & $631 \pm 42$ & $1597 \pm 96$ & $2,534 \pm 0,053$ \\
\hline 2 & 2 & 2 & $16-30$ & $605 \pm 76$ & $1776 \pm 136$ & $2,996 \pm 0,186$ \\
\hline 2 & 2 & 2 & $17-45$ & $752 \pm 29$ & $2161 \pm 87$ & $2,878 \pm 0,106$ \\
\hline 2 & 2 & 2 & $46-59$ & $693 \pm 58$ & $2470 \pm 69$ & $3,621 \pm 0,225$ \\
\hline 2 & 2 & 2 & $60-73$ & $798 \pm 28$ & $2739 \pm 95$ & $3,436 \pm 0,061$ \\
\hline 2 & 2 & 2 & $74-87$ & $791 \pm 56$ & $2799 \pm 119$ & $3,569 \pm 0,173$ \\
\hline 2 & 3 & 1 & $1-15$ & $650 \pm 26$ & $1607 \pm 84$ & $2,470 \pm 0,041$ \\
\hline 2 & 3 & 1 & $16-30$ & $536 \pm 78$ & $1665 \pm 117$ & $3,239 \pm 0,311$ \\
\hline 2 & 3 & 1 & $17-45$ & $618 \pm 55$ & $1916 \pm 110$ & $3,142 \pm 0,220$ \\
\hline 2 & 3 & 1 & $46-59$ & $701 \pm 41$ & $2296 \pm 74$ & $3,293 \pm 0,127$ \\
\hline 2 & 3 & 1 & $60-73$ & $722 \pm 30$ & $2495 \pm 105$ & $3,454 \pm 0,040$ \\
\hline 2 & 3 & 1 & $74-87$ & $743 \pm 74$ & $2468 \pm 179$ & $3,368 \pm 0,201$ \\
\hline 2 & 3 & 2 & $1-15$ & $558 \pm 45$ & $1459 \pm 127$ & $2,616 \pm 0,102$ \\
\hline 2 & 3 & 2 & $16-30$ & $543 \pm 107$ & $1728 \pm 160$ & $3,437 \pm 0,447$ \\
\hline 2 & 3 & 2 & $17-45$ & $744 \pm 50$ & $2113 \pm 165$ & $2,833 \pm 0,052$ \\
\hline 2 & 3 & 2 & $46-59$ & $731 \pm 85$ & $2590 \pm 248$ & $3,576 \pm 0,128$ \\
\hline 2 & 3 & 2 & $60-73$ & $844 \pm 102$ & $2879 \pm 257$ & $3,465 \pm 0,164$ \\
\hline 2 & 3 & 2 & $74-87$ & $848 \pm 125$ & $3016 \pm 306$ & $3,671 \pm 0,270$ \\
\hline
\end{tabular}


Tabela 11 - Médias estimadas e respectivos erros padrão (EP) para ganho de peso diário (GPD45), consumo de ração diário (CRD45) e conversão alimentar (CA45), por animal, envolvendo a fase de crescimento ( 1 a 45 dias), referentes à granulometria (GRAN), área por animal (ÁREA) e sexo.

\begin{tabular}{|c|c|c|c|c|c|}
\hline \multirow[t]{2}{*}{ GRAN } & \multirow[t]{2}{*}{ AREA } & \multirow[t]{2}{*}{ SEXO } & GPD45 & CRD45 & CA45 \\
\hline & & & média $\pm \mathrm{EP}$ & média $\pm E P$ & média $\pm \mathrm{EP}$ \\
\hline 1 & - & - & $676 \pm 14 a$ & $1865 \pm 39 a$ & $2,769 \pm 0,034 b$ \\
\hline 2 & - & - & $608 \pm 13 b$ & $1750 \pm 34 \mathrm{~b}$ & $2,915 \pm 0,047 \mathrm{a}$ \\
\hline- & 1 & - & $600 \pm 14 b$ & $1725 \pm 41 b$ & $2,890 \pm 0,047 \mathrm{~B}$ \\
\hline- & 2 & - & $670 \pm 16 a$ & $1856 \pm 45 \mathrm{a}$ & $2,783 \pm 0,038 \mathrm{~A}$ \\
\hline- & 3 & - & $657+19 a$ & $1842 \pm 48 \mathrm{ab}$ & $2,855 \pm 0,065 \mathrm{~B}$ \\
\hline- & - & 1 & $626 \pm 11 a$ & $1757 \pm 31 b$ & $2,826 \pm 0,039 a$ \\
\hline- & - & 2 & $658+16 a$ & $1857 \pm 41 \mathrm{a}$ & $2,859 \pm 0,045 \mathrm{a}$ \\
\hline
\end{tabular}

a,b Dentro de uma mesma fonte de variação, médias ligadas por letras distintas, na coluna, diferem $(\mathbf{P}<0,05)$ pelo teste de Tukey.

A,B Dentro de uma mesma fonte de variação, médias ligadas por letras distintas, na coluna, diferem $(P<0,10)$ pelo teste de Tukey.

Tabela 12 - Médias estimadas e respectivos erros padrão (EP) para ganho de peso diário (GPD87), consumo de ração diário (CRD87) e conversão alimentar (CA87), por animal, envolvendo a fase crescimento-terminação (1 a 87 dias), referentes à granulometria (GRAN), área por animal (ÁREA) e sexo.

\begin{tabular}{|c|c|c|c|c|c|}
\hline \multirow[t]{2}{*}{ GRAN } & \multirow[t]{2}{*}{ AREA } & \multirow[t]{2}{*}{ SEXO } & GPD87 & CRD87 & CA87 \\
\hline & & & média $\pm E P$ & médiatEP & média $\pm \mathrm{EP}$ \\
\hline 1 & - & - & $733 \pm 11 a$ & $2256 \pm 42 a$ & $3,073 \pm 0,035 \mathrm{~b}$ \\
\hline 2 & - & - & $672 \pm 11 b$ & $2156 \pm 43 b$ & $3,216 \pm 0,039 \mathrm{a}$ \\
\hline- & 1 & - & $664 \pm 12 b$ & $2109 \pm 49 b$ & $3,174 \pm 0,043 \mathrm{~B}$ \\
\hline - & 2 & - & $723 \pm 13 a$ & $2246 \pm 51 \mathrm{ab}$ & $3,103 \pm 0,044 \mathrm{~A}$ \\
\hline- & 3 & - & $720 \pm 15 a$ & $2262 \pm 56 a$ & $3,156 \pm 0,050 \mathrm{~B}$ \\
\hline- & - & 1 & $682 \pm 10 b$ & $2119 \pm 37 b$ & $3,111 \pm 0,035 b$ \\
\hline- & - & 2 & $723 \pm 12 \mathrm{a}$ & $2293 \pm 47 \mathrm{a}$ & $3,178 \pm 0,040 \mathrm{a}$ \\
\hline
\end{tabular}

a,b Dentro de uma mesma fonte de variação, médias ligadas por letras distintas, na coluna, diferem $(P<0,05)$ pelo teste de Tukey.

$A, B$ Dentro de uma mesma fonte de variação, médias ligadas por letras distintas, na coluna, diferem $(\mathrm{P}<0,20)$ pelo teste de Tukey. 
Tabela 13 - Número e respectiva porcentagem de animais normais, com hiperqueratose ou com úlcera, referentes às diferentes combinações (granulometria $\mathrm{x}$ área $\mathrm{x}$ sexo).

\begin{tabular}{|c|c|c|c|c|c|c|c|c|}
\hline \multicolumn{3}{|c|}{$\begin{array}{l}\text { Combinação de } \\
\text { tratamentos* }\end{array}$} & \multicolumn{2}{|c|}{ Animais normais } & \multicolumn{2}{|c|}{$\begin{array}{c}\text { Animais com } \\
\text { hiperqueratose }\end{array}$} & \multicolumn{2}{|c|}{$\begin{array}{c}\text { Animais com } \\
\text { úlcera }\end{array}$} \\
\hline Gran & Área & Sexo & Número & $\%$ & Número & $\%$ & Número & $\%$ \\
\hline 1 & 1 & 1 & 3 & 1,00 & 26 & 8,67 & 9 & 3,00 \\
\hline 1 & 1 & 2 & 2 & 0,67 & 23 & 7,67 & 11 & 3,67 \\
\hline 1 & 2 & 1 & 0 & 0,00 & 19 & 6,33 & 4 & 1,33 \\
\hline 1 & 2 & 2 & 1 & 0,33 & 18 & 6,00 & 4 & 1,33 \\
\hline 1 & 3 & 1 & 4 & 1,33 & 9 & 3,00 & 3 & 1,00 \\
\hline 1 & 3 & 2 & 1 & 0,33 & 10 & 3,33 & 5 & 1,67 \\
\hline 2 & 1 & 1 & 19 & 6,33 & 15 & 5,00 & 2 & 0,67 \\
\hline 2 & 1 & 2 & 16 & 5,33 & 12 & 4,00 & 8 & 2,67 \\
\hline 2 & 2 & 1 & 11 & 3,67 & 9 & 3,00 & 2 & 0,67 \\
\hline 2 & 2 & 2 & 10 & 3,33 & 9 & 3,00 & 4 & 1,33 \\
\hline 2 & 3 & 1 & 11 & 3,67 & 5 & 1,67 & 0 & 0,00 \\
\hline 2 & 3 & 2 & 9 & 3,00 & 4 & 1,33 & 2 & 0,67 \\
\hline 1 & 1 & - & 5 & 1,67 & 49 & 16,33 & 20 & 6,67 \\
\hline 1 & 2 & - & 1 & 0,33 & 37 & 12,33 & 8 & 2,67 \\
\hline 1 & 3 & - & 5 & 1,67 & 19 & 6,33 & 8 & 2,67 \\
\hline 2 & 1 & - & 35 & 11,67 & 27 & 9,00 & 10 & 3,33 \\
\hline 2 & 2 & - & 21 & 7,00 & 18 & 6,00 & 6 & 2,00 \\
\hline 2 & 3 & - & 20 & 6,67 & 9 & 3,00 & 2 & 0,67 \\
\hline 1 & - & 1 & 7 & 2,33 & 54 & 18,00 & 16 & 5,33 \\
\hline 1 & - & 2 & 4 & 1,33 & 51 & 17,00 & 20 & 6,67 \\
\hline 2 & - & 1 & 41 & 13,67 & 29 & 9,67 & 4 & 1,33 \\
\hline 2 & - & 2 & 35 & 11,67 & 25 & 8,33 & 14 & 4,67 \\
\hline - & 1 & 1 & 22 & 7,33 & 41 & 13,67 & 11 & 3,67 \\
\hline- & 1 & 2 & 18 & 6,00 & 35 & $11,67$. & 19 & 6,33 \\
\hline - & 2 & 1 & 11 & 3,67 & 28 & 9,33 & 6 & 2,00 \\
\hline- & 2 & 2 & 11 & 3,67 & 27 & 9,00 & 8 & 2,67 \\
\hline- & 3 & 1 & 15 & 5,00 & 14 & 4,67 & 3 & 1,00 \\
\hline- & 3 & 2 & 10 & 3,33 & 14 & 4,67 & 7 & 2,33 \\
\hline 1 & - & - & 11 & 3,67 & 105 & 35,00 & 36 & 12,00 \\
\hline 2 & - & - & 76 & 25,33 & 54 & 18,00 & 18 & 6,00 \\
\hline - & 1 & - & 40 & 13,33 & 76 & 25,33 & 30 & 10,00 \\
\hline - & 2 & - & 22 & 7,33 & 55 & 18,33 & 14 & 4,67 \\
\hline- & 3 & - & 25 & 8,33 & 28 & 9,33 & 10 & 3,33 \\
\hline - & - & 1 & 48 & 16,00 & 83 & 27,67 & 20 & 6,67 \\
\hline- & - & 2 & 39 & 13,00 & 76 & 25,33 & 34 & 11,33 \\
\hline
\end{tabular}

* Gran 1 = milho moido em peneira de $2,5 \mathrm{~mm}$; Gran2 = milho moido em peneira de $10,0 \mathrm{~mm}$; Árcal $=0,64 \mathrm{~m}^{2} /$ animal; Área2 $=1,07 \mathrm{~m}^{2} /$ animal; Área3 $=1,60 \mathrm{~m}^{2} /$ animal; Sexol $=$ fêmea; Sexo2 $=$ macho . 
Tabela 14 - Análise de variância discreta para a variável lesão gástrica.

\begin{tabular}{|c|c|c|c|}
\hline FONTES DE VARIAÇÄO & GL & QUIQUADRADO & PROBABILIDADE \\
\hline Granulometria (Gran) & 1 & 29,45 & 0,0000 \\
\hline Área por animal (Área) & 2 & 2,18 & 0,3359 \\
\hline Sexo & 1 & 3,08 & 0,0791 \\
\hline Gran $\times$ Sexo & 1 & 0,42 & 0,5163 \\
\hline Gran x Area & 2 & 0,02 & 0,9904 \\
\hline Sexo x Área & 2 & 1,32 & 0,5160 \\
\hline Gran x Área x Sexo & 2 & 0,39 & 0,8219 \\
\hline \multicolumn{4}{|l|}{ Desdobramentos } \\
\hline Gran $\mid$ Área $=1$ & 1 & 18,61 & 0,0000 \\
\hline Gran $\mid$ Área $=2$ & 1 & 8,34 & 0,0039 \\
\hline Gran $\mid$ Área $=3$ & 1 & 7,81 & 0,0052 \\
\hline Área | Gran = 1 & 2 & 1,13 & 0,5686 \\
\hline Área $12 / \mathrm{Gran}=1$ & 1 & 0,10 & 0,7558 \\
\hline Area $13 \mid$ Gran $=1$ & 1 & 0,78 & 0,3775 \\
\hline Área $23 \mid$ Gran $=1$ & 1 & 0,87 & 0,3509 \\
\hline Área | Gran $=2$ & 2 & 1,09 & 0,5787 \\
\hline Área $12 \mid$ Gran $=2$ & 1 & 0,06 & 0,8030 \\
\hline Área $13 \mid$ Gran $=2$ & 1 & 0,79 & 0,3736 \\
\hline Área 23/Gran = 2 & 1 & 0,73 & 0,3921 \\
\hline Sexo $\mid$ Área $=1$ & 1 & 2,64 & 0,1043 \\
\hline Sexo $\mid$ Área $=2$ & 1 & 0,00 & 0,9639 \\
\hline Sexo $\mid$ Área = 3 & 1 & 2,71 & 0,1000 \\
\hline Área $\mid$ Sexo $=1$ & 2 & 8,48 & 0,0144 \\
\hline Área $12 \mid$ Sexo $=1$ & 1 & 0,61 & 0,4356 \\
\hline Área $13 /$ Sexo $=1$ & 1 & 1,35 & 0,2453 \\
\hline Área 23| Sexo = 1 & 1 & 7,91 & 0,0049 \\
\hline Área $\mid$ Sexo $=2$ & 2 & 0,35 & 0,8391 \\
\hline Área 12| Sexo = 1 & 1 & 0,12 & 0,7255 \\
\hline Área 13| Sexo = 1 & 1 & 0,32 & 0,5733 \\
\hline Área 23| Sexo = 1 & 1 & 0,00 & 0,9529 \\
\hline Gran $\mid$ Sexo = 1 & 1 & 15,16 & 0,0001 \\
\hline Gran $\mid$ Sexo $=2$ & 1 & 14,57 & 0,0001 \\
\hline Sexo $\mid$ Gran = 1 & 1 & 0,52 & 0,4715 \\
\hline Sexo $\mid$ Gran $=2$ & 1 & 3,53 & 0,0603 \\
\hline Gran 12 & 1 & 29,45 & 0,0000 \\
\hline Sexo 12 & 1 & 3,08 & 0,0791 \\
\hline Área 12 & 1 & 0,16 & 0,6926 \\
\hline Área 13 & 1 & 1,57 & 0,2106 \\
\hline Área 23 & 1 & 1,90 & 0,1681 \\
\hline
\end{tabular}


Tabela 15 - Associação de lesão com área e granulometria e seus efeitos sobre o ganho de peso, na fase crescimento-terminação ( 87 dias).

\begin{tabular}{|c|c|c|c|c|}
\hline \multirow[b]{2}{*}{ Lesão } & \multirow[b]{2}{*}{ Granulometria } & \multirow[b]{2}{*}{ Área por animal } & \multicolumn{2}{|c|}{ Ganho de peso diário (g) 87 dias } \\
\hline & & & Média & Erro Padrão \\
\hline Normal & $2,5 \mathrm{~mm}$ & $0,64 \mathrm{~m}^{2} /$ animal & 690 & 45 \\
\hline Normal & $2,5 \mathrm{~mm}$ & $1,07 \mathrm{~m}^{2}$ tanimat & 600 & 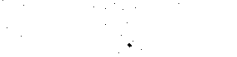 \\
\hline Normal & $2,5 \mathrm{~mm}$ & $1,60 \mathrm{~m}^{2} /$ animal & 651 & 55 \\
\hline Normal & $10,0 \mathrm{~mm}$ & $0,64 \mathrm{~m}^{2} /$ animal & 677 & 24 \\
\hline Normal & $10,0 \mathrm{~mm}$ & $1,07 \mathrm{~m}^{2} /$ animal & 675 & 26 \\
\hline Normal & $10,0 \mathrm{~mm}$ & $1,60 \mathrm{~m}^{2} / \mathrm{animal}$ & 701 & 22 \\
\hline Hiperqueratose & $2,5 \mathrm{~mm}$ & $0,64 \mathrm{~m}^{2} /$ animal & 725 & 18 \\
\hline Hiperqueratose & $2,5 \mathrm{~mm}$ & $1,07 \mathrm{~m}^{2} /$ animal & 795 & 18 \\
\hline Hiperqueratose & $2,5 \mathrm{~mm}$ & $1,60 \mathrm{~m}^{2} /$ animal & 781 & 22 \\
\hline Hiperqueratose & $10,0 \mathrm{~mm}$ & $0,64 \mathrm{~m}^{2} /$ animal & 640 & 27 \\
\hline Hiperqueratose & $10,0 \mathrm{~mm}$ & $1,07 \mathrm{~m}^{2} /$ animal & 681 & 43 \\
\hline Hiperqueratose & $10,0 \mathrm{~mm}$ & $1,60 \mathrm{~m}^{2} /$ animal & 648 & 63 \\
\hline Úlcera & $2,5 \mathrm{~mm}$ & $0,64 \mathrm{~m}^{2} /$ animal & 618 & 28 \\
\hline Úlcera & $2,5 \mathrm{~mm}$ & $1,07 \mathrm{~m}^{2} /$ animal & 681 & 43 \\
\hline Úlcera & $2,5 \mathrm{~mm}$ & $1,60 \mathrm{~m}^{2} /$ animal & 749 & 65 \\
\hline Úlcera & $10,0 \mathrm{~mm}$ & $0,64 \mathrm{~m}^{2} /$ animal & 608 & 38 \\
\hline Úlcera & $10,0 \mathrm{~mm}$ & $1,07 \mathrm{~m}^{2}$ /animal & 702 & 48 \\
\hline Úlcera & $10,0 \mathrm{~mm}$ & $1,60 \mathrm{~m}^{2} /$ animal & 659 & 209 \\
\hline
\end{tabular}

Tabela 16 - Associação de lesão com granulometria e seus efeitos sobre o ganho de peso, na fase crescimento-terminação (87 dias)

\begin{tabular}{lccc}
\hline & & \multicolumn{2}{c}{ Ganho de peso diário (g) 87 dias } \\
\cline { 3 - 4 } Lesão & Granulometria & Média & Erro Padrão \\
\hline Normal & $2,5 \mathrm{~mm}$ & 664 & 32 \\
Normal & $10,0 \mathrm{~mm}$ & 683 & 14 \\
Hiperqueratose & $2,5 \mathrm{~mm}$ & 760 & 12 \\
Hiperqueratose & $10,0 \mathrm{~mm}$ & 655 & 22 \\
Úlcera & $2,5 \mathrm{~mm}$ & 661 & 24 \\
Úlcera & $10,0 \mathrm{~mm}$ & 645 & 33 \\
\hline
\end{tabular}


Tabela 17 - Associação de lesão com área por animal e seus efeitos sobre o ganho de peso, nas fases de crescimento (45 dias) e crescimento-terminação (87 dias).

\begin{tabular}{lccc} 
& & & \\
& & & \\
\cline { 3 - 4 } Lesão & Ganho de peso diário (g) 87 dias \\
\cline { 3 - 4 } Normal & $0,64 \mathrm{~m}^{2} /$ animal & Média & Erro Padrão \\
Normal & $1,07 \mathrm{~m}^{2} /$ animat & 679 & 21 \\
Normal & $1,60 \mathrm{~m}^{2} /$ animal & 691 & 25 \\
Hiperqueratose & $0,64 \mathrm{~m}^{2} /$ animal & 695 & 20 \\
Hiperqueratose & $1,07 \mathrm{~m}^{2} /$ animal & 758 & 16 \\
Hiperqueratose & $1,60 \mathrm{~m}^{2} /$ animal & 738 & 20 \\
Úlcera & $0,64 \mathrm{~m}^{2} /$ animal & 614 & 27 \\
Úlcera & $1,07 \mathrm{~m}^{2} /$ animal & 690 & 22 \\
Úlcera & $1,60 \mathrm{~m}^{2} /$ animal & 731 & 31 \\
\hline
\end{tabular}

Tabela 18 - Efeito da granulometria sobre o ganho de peso, nas fases de crescimento (45 dias) e crescimento-terminação ( 87 dias).

\begin{tabular}{|c|c|c|}
\hline & Ganho de peso diário (g) 45 dias & Ganho de peso diário $(\mathrm{g}) 87$ dias \\
\hline Granulometria & Média \pm Erro Padrão & Média \pm Erro Padrão \\
\hline $2,5 \mathrm{~mm}$ & $676 \pm 11 a$ & $730 \pm 11 a$ \\
\hline $10,0 \mathrm{~mm}$ & $613 \pm 12 b$ & $668 \pm 12 b$ \\
\hline
\end{tabular}

a,b médias ligadas por letras distintas, na coluna, diferem $(P>0,05)$ pelo teste de Tukey.

Tabela 19 - Efeito das lesões gástricas sobre o ganho de peso, na fase crescimento-terminação (87 dias).

\begin{tabular}{lc}
\hline & Ganho de peso diário $(\mathrm{g}) 87$ dias \\
\cline { 2 - 2 } Lesão & Média \pm Erro Padrão \\
\hline Normal & $680 \pm 13$ ab \\
Hiperqueratose & $724 \pm 11 \mathrm{a}$ \\
Úlcera & $655 \pm 19 \mathrm{~b}$ \\
$\mathrm{a}, \mathrm{b}$ & $\begin{array}{l}\text { médias ligadas por letras distintas, na coluna, diferem }(\mathrm{P}>0,05) \\
\text { pelo teste de Tukey. }\end{array}$
\end{tabular}


Tabela 20 - Análise de variância da associação da lesão gástrica com granulometria e área por animal, referente ao ganho de peso, durante todo o período experimental (1 a 87 dias).

\begin{tabular}{|c|c|c|c|c|c|}
\hline Fontes de Variação & $\overline{G L}$ & $\begin{array}{l}\text { Soma de } \\
\text { Quadrados }\end{array}$ & $\begin{array}{c}\text { Quadrado } \\
\text { Médio }\end{array}$ & Valor F & $P>F$ \\
\hline Lesão & 2 & 75142.24 & 37571.12 & 2.17 & 0.1165 \\
\hline Granulometria (Gran) & 1 & 30843.66 & 30843.66 & 1.78 & 0.1834 \\
\hline Lesão x Gran & 2 & 131646.14 & 65823.07 & 3.80 & 0.0236 \\
\hline Área por animal (Área) & 2 & 42805.52 & 21402.76 & 1.23 & 0.2926 \\
\hline Lesão x Área & 4 & 55225.22 & 13806.30 & 0.80 & 0.5285 \\
\hline Gran x Área & 2 & 9832.69 & 4916.36 & 0.28 & 0.7534 \\
\hline Lesão x Gran x Área & 4 & 32095.92 & 8023.98 & 0.46 & 0.7631 \\
\hline lesão/granulometria 1 & 2 & 220621.22 & 110310.61 & 6.36 & 0.0020 \\
\hline lesãolgranulometria 2 & 2 & 24275.91 & 12137.96 & 0.70 & 0.4975 \\
\hline normal x ulcera 1 & 1 & 6653.20 & 6653.20 & 0.38 & 0.5362 \\
\hline normal $x$ ulcera 2 & 1 & 8023.36 & 8023.36 & 0.46 & 0.4969 \\
\hline hiperqueratose $\mathrm{x}$ ulcera 1 & 1 & 161004.70 & 161004.70 & 9.28 & 0.0025 \\
\hline hiperqueratose $\mathrm{x}$ ulcera 2 & 1 & 2.20 & 2.20 & 0.00 & 0.9910 \\
\hline norm $x$ hiperq $\times$ ulcera 1 & 1 & 8065.22 & 8065.22 & 0.47 & 0.4958 \\
\hline norm $x$ hiperg $x$ ulcera 2 & 1 & 2182.51 & 2182.51 & 0.13 & 0.7230 \\
\hline Total & \multicolumn{2}{|l|}{298} & & & \\
\hline $\mathrm{R}^{2}(\%)$ & & & & & \\
\hline
\end{tabular}

